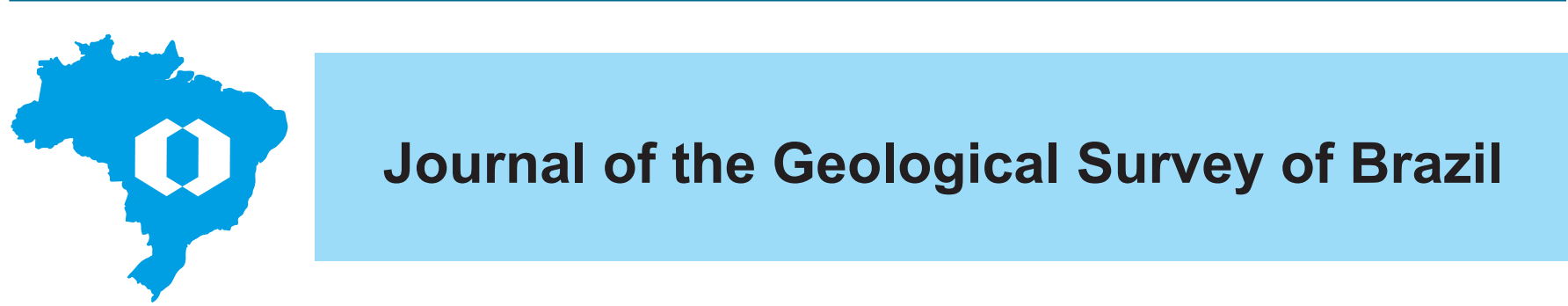

\title{
The Archean Rio das Velhas greenstone belt revisited: new insights into the stratigraphy
}

\author{
Joanna Chaves Souto Araújo ${ }^{1 *}$, (i) Raianny Carolini Ramos Ferreira ${ }^{1}$, (D) Frederico Moreira Freitas ${ }^{1}$, \\ Joana Reis Magalhães ${ }^{1}$
}

\section{Abstract}

The Neoarchean Rio das Velhas greenstone belt (RVGB), southeast Brazil, contains major tectonic and stratigraphic discontinuities that allow its division into three fault-bound tectonostratigraphic blocks named Santa Bárbara, Nova Lima-Caeté and São Bartolomeu. Detailed 1:25,000 scale mapping of the RVGB northern part revealed that each block contains important particularities and were subdivided into different lithostratigraphic formal units. The Santa Bárbara block comprises the basal ultrabasic rocks of the Quebra Osso Group, followed by metavolcano-sedimentary successions of the Nova Lima Group (Vigário da Vara, Santa Quitéria, and Córrego do Sítio formations), and metasedimentary rocks of the Maquiné Group (Palmital and Casa Forte formations). The Nova Lima-Caeté block comprises the basal ultrabasic/basic volcanism (Ouro Fino and Morro Vermelho formations), metavolcano-sedimentary sequences (Mestre Caetano and Ribeirão do Brumado formations) of the Nova Lima Group, and the upper clastic sedimentary rocks of the Maquiné Group (Palmital and Casa Forte formations). The São Bartolomeu block has a distinct rock assemblage given by metasedimentary rocks of the Nova Lima Group (Fazenda Velha, Córrego da Paina, and Pau D'Óleo formations), and clastic sedimentary rocks of the Maquiné Group (Andaimes Formation). Despite some remarkable differences between these blocks, it is possible to recognize stratigraphic correlations and similar depositional evolution. The authors suggest volcanic architecture and sedimentary depositional models for the studied area, which includes: i) fissure eruption of komatiite lavas of the Quebra Osso Group, in the SB block, with subordinate clasto-chemical sedimentation; ii) ultrabasic/basic volcanism related to multiple volcanic centers in a subaqueous environment, characteristic from the basal portion of the Nova Lima Group in the SB and NLC blocks; iii) intermediate to acid volcanic and volcaniclastic rocks from the Nova Lima Group, present only in the NLC block, related to explosive eruptions; iv) clasto-chemical sedimentation, well recorded in the SB block; v) thick sequence of clastic sediments recorded in the three blocks with a predominance of greywacke-argillite cycles, deposited by turbidity currents in tectonically active submarine basins; vi) metasediments formed in alluvial-fluvial, coastal and shallow marine environments of the Maquiné Group.
Article Information

Publication type: Review articles Received 14 May 2020

Accepted 17 October 2020

Online pub. 19 November 2020

Editor: E. Klein

Keywords:

Greenstone Belt,

Quadrilátero Ferrífero,

Stratigraphy,

Depositional model,

Volcanic architecture

${ }^{*}$ Corresponding author

Joanna Chaves Souto Araújo

E-mail address: joanna.araujo@cprm.gov.br

\section{Introduction}

Greenstone belts are, in general, greenschist facies thick sequences of underwater-deposited volcanic and sedimentary rocks preserved in cratonic regions. However, greenstone belts may differ in rock assemblages, metamorphic and deformation histories, structural arrangements, and tectonic complexity. These differences reflect the diversity of such associations (e.g., Anhaeusser 2014; and references therein). Greenstone belts are also known to host important ore-deposits such as orogenic $\mathrm{Au}$, komatiite $\mathrm{Ni}, \mathrm{Cu}-\mathrm{Zn}$ volcanogenic massive sulfide (VMS), rare metal pegmatites and complex Ag-Co ore (e.g., Groves and Barley 1994; Herrington et al. 1997).
The Rio das Velhas greenstone belt (RVGB), located at the southern edge of the São Francisco craton, in southeastern Brazil (Fig. 1A), is a part of the Quadrilátero Ferrífero ('Iron Quadrangle') region (Fig. 1B), an important metallogenic province (Dorr II et al. 1957; Dorr II 1969; Lobato et al. 2001a, b). Its several world-class iron and gold deposits turned it into one of the most intensively studied granite-greenstone terranes of Brazil. The classical studies provided essential details and significant contributions for the tectonostratigraphic evolution of this belt (e.g., Baltazar and Zucchetti 2007; and references therein). However, much remains to be done in order to understand its complex stratigraphy and shed light on its lithostratigraphic compartments. 
The Archean Rio das Velhas granite-greenstone terrane contains two main components: the supracrustal rock sequence and the associated TTG-gneisses and metagranitoids (Fig. $1 \mathrm{~B})$. The supracrustal sequence, which is the focus of this discussion, consists of a metavolcano-sedimentary sequence that makes up the RVGB and has been assigned to the Rio das Velhas Supergroup (Loczy and Ladeira 1976).

The paper aims to present a systematic review of the cartography and stratigraphy of the Rio das Velhas greenstone belt, combining new geological mapping and petrography. The research was developed during the Quadrilátero Ferrífero (QF) Project from the Geological Survey of Brazil, and resulted in the publication of 16 geological maps (1:25,000 scale; Araújo et al. 2020a, b, c, d; Cavalcanti et al. 2020a, b, c, d, e; Ferreira et al. 2020a, b, c, d; Freitas et al. 2020a, b, c) and an integration map (1:75,000 scale; Silva et al. 2020) (Fig. 1C).

The field studies revealed that the belt contains major tectonic and stratigraphic discontinuities, as well as

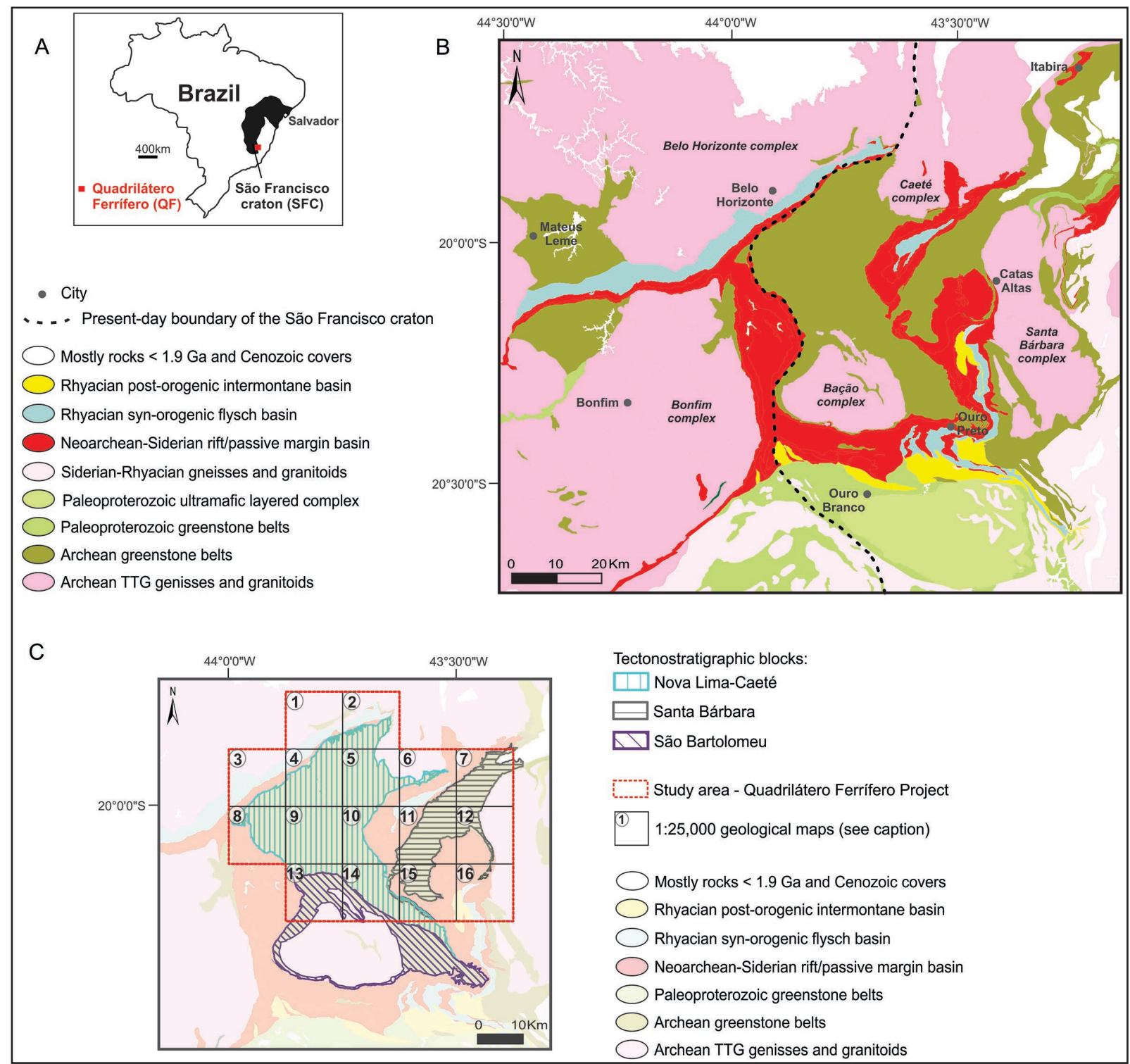

FIGURE 1. A) - Location of the Quadrilátero Ferrífero region at the São Francisco craton southeastern border, southeastern Brazil. B) - Simplified geological map of the QF region highlighting Archean greenstone belts, Archean crystalline basement and Neoarchean-Paleoproterozoic metasedimentary units. Modified from Pinto and Silva (2014) and Alkmim and Teixeira (2017). C) - Simplified map showing the subdivision of the Rio das Velhas greenstone belt into three tectonostratigraphic blocks, according to Baltazar and Zucchetti (2007), and the following 1:25,000 geological maps: 1- Santa Luzia (Cavalcanti et al. 2020d); 2- Serra da Piedade (Araújo et al. 2020d); 3- Belo Horizonte (Cavalcanti et al. 2020a); 4- Nova Lima (Cavalcanti et al. 2020b); 5- Caeté (Araújo et al. 2020a); 6- Gongo Soco (Araújo et al. 2020c); 7- Santa Bárbara (Ferreira et al. 2020c); 8- São Sebastião das Águas Claras (Cavalcanti et al. 2020e); 9- Rio Acima (Cavalcanti et al. 2020c); 10- Gandarela (Araújo et al. 2020b); 11- Conceição do Rio Acima (Ferreira et al. 2020b); 12- Catas Altas (Ferreira et al. 2020a); 13- Itabirito (Freitas et al. 2020b); 14- Rio de Pedras (Freitas et al. 2020c); 15- Capanema (Freitas et al. 2020a); 16- Santa Rita Durão (Ferreira et al. 2020d). 
structurally repeated rock sequences, all related to a complex evolution. In this sense, to better characterize the RVGB, we adopted Baltazar and Zucchetti (2007) proposal to subdivide it into three tectonostratigraphic blocks bound by major structural lineaments (Fig. 1C). Once these blocks differ in their supracrustal rock record (Fig. 2), different stratigraphic columns (Fig. 3) will represent each one. Considering that the stratigraphic nomenclature of the RVGB has so far been considered informal in the literature, we also aim to propose a formal nomenclature for each block (Table 1), in analogy with that proposed by Pinto and Silva (1996), and suggest possible correlations between them.

\section{Geological context and background}

The Archean RVGB crops out in the QF region along with Archean granite-gneiss complexes and structurally underlies Neoarchean-Paleoproterozoic metasedimentary units (Fig. 1B; Dorr II et al. 1957; Dorr II 1969; Alkmim and Marshak 1998; Zucchetti and Baltazar 2000; Lana et al. 2013).

The Archean granite-gneisses are represented by five TTG's assemblages known as the Santa Bárbara, Bação, Bonfim, Belo Horizonte and Caeté complexes (e.g., Machado and Carneiro 1992; Machado et al. 1992; Noce et al. 1998; Farina et al. 2015). Isotopic U-Pb zircon data revealed that rocks of the Santa Bárbara Complex crystallized at ca. 3,210 Ma (Lana et al. 2013), being the oldest crustal fragment in the QF region. However, the Bação, Bonfim, Belo Horizonte and Caeté complexes (Fig. 1B) formed during the agespan of 2,920 to 2,760 Ma (e.g., Lana et al. 2013; Farina et al. 2015). These TTG complexes were intruded by high-K granitoid batholiths between 2,750 and 2,600 Ma (e.g., Lana et al. 2013; Romano et al. 2013). In detail, the Archean TTG crustal evolution has been divided into at least five magmatic episodes named Santa Bárbara (3,220-3,200 Ma), Rio das Velhas I (2,930-2,850 Ma), Rio das Velhas II (2,800-2,760 $\mathrm{Ma})$, Mamona I (2,760-2,680 Ma) and Mamona II (2,650-2,580 Ma) (Lana et al. 2013; Farina et al. 2015; Dopico et al. 2017).

The metavolcano-sedimentary rocks of the RVGB occur as elongated slivers around the basement gneiss domes (Fig. 1B). Historically, these supracrustal rocks correspond to the Rio das Velhas Supergroup, subdivided, from base to the top, into the Nova Lima and Maquiné groups (Dorr II 1969; Loczy and Ladeira 1976). This sequence was considered a greenstone belt after Almeida (1976) and Schorscher (1976), due to its similarities with other worldwide sequences. However, the RVGB most significant feature is the predominance of sedimentary rocks, accompanied by minor volcanic components, as already mentioned by Zucchetti et al. 2000c, unlike most greenstone belts. The prevalence of sedimentary rocks resembles the Canadian Slave Province in Canada, where about $70 \%$ of the supracrustal rocks are turbidites (Padgham and Fyson 1992).

Several stratigraphic subdivisions have been proposed for the Rio das Velhas Supergroup (Zucchetti and Baltazar 2000; and references therein). The main debate in the previous subdivisions regards the basal komatiitic unit of the RVGB that outcrops in the Santa Bárbara region (Fig. 2). Schorscher (1979) proposed to assign these komatiites, as well as the associated Algoma-type BIF (banded iron formation) and metavolcaniclastic rocks, under a new unit named the Quebra Osso Group at the base of the Rio das Velhas Supergroup.
Baltazar and Raposo (1993) claimed that this association should be placed at the base of the Nova Lima Group and renamed it as Quebra Osso unit. However, the stratigraphic position and meaning of the Quebra Osso unit remain under debate.

The contact of the Nova Lima Group with the TTG basement complexes is tectonic. The Group consists of ultrabasic and basic volcanic rocks interleaved with Algomatype BIF, metagreywackes, quartzites, ferruginous metachert, and carbonaceous metapelites, and acid and intermediate volcanic rocks (Dorr II 1969; Zucchetti et al. 2000c). The ultrabasic rocks are either massive or pillowed komatiitic metabasalt that occur associated with tholeiitic metabasalts (Zucchetti 1998; Zucchetti et al. 2000c). Zucchetti (1998) and Silva (2000) report that the geochemistry of the basic lavas is compatible with $\mathrm{N}-\mathrm{MORB}$, and suggest that the eruptions took place in an oceanic environment under an extensional regime. The intermediate section of the Nova Lima Group comprises metapelites interleaved with BIF, metacherts, metagreywackes, carbonaceous metapelites, and acid/ intermediate metavolcaniclastic rocks deposited in a deep marine environment. The top of the Nova Lima Group consists of turbidites, epiclastic, and volcaniclastic rocks (Baltazar and Zucchetti 2007).

In the 1990s, during the first geological mapping performed by the Geological Survey of Brazil in the RVGB (CPRM 1994, 1996; Zucchetti and Baltazar 2000), the Nova Lima Group was subdivided into twelve informal units named as Quebra Osso, Ouro Fino, Morro Vermelho, Santa Quitéria, Ribeirão Vermelho, Mestre Caetano, Catarina Mendes, Córrego da Paina, Fazenda Velha, Pau D'Óleo, Mindá, and Córrego do Sítio (Baltazar and Silva 1996; Pedreira and Silva 1996; Baltazar and Pedreira 2000; Zucchetti et al. 2000c). These units were then grouped by Zucchetti et al. (2000c) and Baltazar and Zucchetti (2007) into seven lithofacies associations characterized by their own sedimentary/volcanic natures, as follows: (1) volcanic maficultramafic; (2) volcano-chemical-sedimentary; (3) clasticchemical-sedimentary; (4) volcaniclastic; (5) resedimented; (6) coastal, and (7) non-marine.

Ultrabasic-basic rocks of the Córrego dos Boiadeiros Suite (Schrank et al. 1990; Costa et al. 1992; Zucchetti and Baltazar 2000) intrude the basal sequence of the Nova Lima Group. These rocks are serpentinites, talc-schists, and metagabbros of volcanic to subvolcanic regimes (Gair 1962; Costa 1995). According to Schrank et al. (1990), at least part of the Córrego dos Boiadeiros Suite represents a layered intrusion.

The Maquiné Group, top unit of the Rio das Velhas Supergroup, comprises quartzites, quartz-mica schists, and subordinate metaconglomerates deposited under shallow marine (coastal) and fluvial environments (Dorr II 1969; Zucchetti et al. 2000c). The contact between the Nova Lima and Maquiné groups can be gradual, discordant, or tectonic (Zucchetti et al. 2000c). The Group was previously divided, from base to top, into the Palmital (O'Rourke 1957), and Casa Forte Formations (Gair 1962). The Palmital Formation consists of metaturbidites, quartz-schists, and quartzites, whose protoliths deposited in a proximal marine environment. As some contacts between the Maquiné and the Nova Lima groups are gradual, Baltazar and Zucchetti (2007) suggest that the Palmital Formation is a part of the Nova Lima Group coastal association. The Casa Forte Formation, on the other hand, is a sequence of fluvial meta-arenites and metaconglomerates (Baltazar and Zucchetti 2007). 
Isotopic U-Pb zircon data are available for several rocktypes of the Nova Lima Group. Machado et al. $(1989,1992)$ report that felsic volcanic rocks of the basal section yielded ages of 2,776 \pm 23 and 2,772 \pm 6 Ma. Machado et al. (1996) obtained maximum depositional age of 2,996 \pm 38 Ma from a metagreywacke sample, whereas Noce et al. (2005) obtained ages of 2,792 \pm 11 and 2,751 $\pm 9 \mathrm{Ma}$ from metavolcaniclastic greywacke samples. Schrank and Machado (1996), on the other hand, revealed an age-span of 2,771 to 2,705 Ma from the Lapa Seca carbonatic rock. Quartzites of the top of the Nova Lima Group yielded maximum depositional ages around $2,679 \pm 20 \mathrm{Ma}$ (Dopico et al. 2017). Additionally, Coelho (2015) obtained ages of 2,744 $\pm 6 \mathrm{Ma}$ and 2,761 \pm 4 Ma for amphibolite and garnet-bearing metashale samples, respectively. More recently, Freitas et al. (2019) revealed a maximum depositional age of 2,098 \pm 34 Ma from metagreywacke samples of the Catarina Mendes Formation. So far, this formation was placed at the top of the Nova Lima Group, but the zircon ages show that the source-area for the greywackes was Rhyacian in age and, therefore, considerably younger than all the other units of the Rio das Velhas Supergroup.

According to Moreira et al. (2016), the Maquiné Group yielded $\mathrm{U}-\mathrm{Pb}$ zircon maximum depositional ages between 2,770 and 2,700 Ma, and the Palmital Formation, basal unit of this Group, show maximum depositional age of 2,740 Ma.

The Nova Lima Group hosts a large number of important gold deposits that are historically responsible for the majority of gold production in the QF region (e.g., Ladeira 1980; Lobato et al. 2001a). These deposits are structurally controlled and mainly hosted by carbonate and oxide-rich BIF, and by a hydrothermally altered rock known as lapa seca. Several mines will be referred to in later paragraphs, but for details, see Ladeira (1985), Lobato et al. (2001a, b), Roncato (2016), and Martins et al. (2016). The age of the local gold mineralization is still controversial, although most authors agree they formed at ca. 2.7 Ga (Lobato et al. 2007; Martins et al. 2016).

Neoarchean-Paleoproterozoic units overlap the RVGB through angular discordances or regional scale faults in the central portion of the QF (Fig. 1B). These units belong to the Minas Supergroup, Sabará Group, and the Itacolomi Group (Fig. 1B; Dorr Il et al. 1957; Dorr II 1969). The Minas Supergroup basin represents a continental rift that evolved to a passive margin, with continental and marine sediments (Alkmim and Marshak 1998; Alkmim and Teixeira 2017). U-Pb depositional ages for these metasedimentary rocks range between ca. 2.7 and $2.5 \mathrm{Ga}$ (Machado et al. 1996; Hartmann et al. 2006; Cabral et al. 2012; Koglin et al. 2014; Nunes 2016; Dopico et al. 2017). Babinski et al. (1995) report that the diagenesis of the Supergroup stromatolitic carbonates yielded a $\mathrm{Pb}-\mathrm{Pb}$ age of 2,420 Ma. The Sabará and Itacolomi groups comprise metasedimentary rocks deposited during a Rhyacian orogeny (Fig. 1B). The Sabará Group consists of synorogenic flysch sediments (Barbosa 1968; Dorr II 1969; Alkmim and Teixeira 2017) and its detrital zircon grains yielded U-Pb maximum depositional ages between 2,125 to 2,036 Ma (Machado et al. 1996; Dutra et al. 2019). The Itacolomi Group comprises sediments deposited in intramontane grabens during the orogenic collapse (Barbosa 1968; Dorr II 1969), with maximum depositional ages between 2,144 and 2,059 Ma, given by U-Pb detrital zircon (Machado et al. 1996; Duque 2018).

The QF region has a complex structural and tectonic evolution. Its geometry results from the uplift of part of the
TTG basement as the core of domes enveloped by large synclines and anticlines commonly truncated by thrust faults. Several models with different interpretations have been proposed to explain this geometry (e.g., Dorr II 1969; Chemale et al. 1994; Marshak et al. 1997; Alkmim and Marshak 1998; Baltazar and Zucchetti 2007; Alkmim and Teixeira 2017). Dorr II (1969) was the first to propose a polyphasic evolution for the $\mathrm{QF}$, represented by three periods. According to Baltazar and Zucchetti (2007), two Archean compressive events affected the RVGB and its TTG complexes, and are thus related to the evolution of the greenstone belt. An extensional event between the Neoarchean and Paleoproterozoic was responsible for the formation of the rift and passive margin basins that received the sedimentary protoliths of the Minas Supergroup (Alkmim and Marshak 1998; Dopico et al. 2017). Subsequently, a Paleoproterozoic compressive event developed a thrust fault system with an NW vergence (Teixeira et al. 2015, 2017). The collapse of this orogeny would have been responsible for the remarkable dome-and-keel structure (e.g., Marshak et al. 1997; Cutts et al. 2019). During the Neoproterozoic, a compressive event induced an E-W shortening with W-verging thrust faults (Chemale et al. 1994; Alkmim and Marshak 1998; Alkmim and Teixeira 2017).

\section{Subdivision into tectonostratigraphic blocks}

The first proposal to subdivide the RVGB into lithostratigraphic domains was made by Zucchetti and Baltazar (2000), based on major structural lineaments, regional shear zones, and stratigraphic particularities. The authors individualized four blocks named Caeté, Nova Lima, Santa Bárbara, and São Bartolomeu. Despite the existence of a prominent thrust fault between the Nova Lima and Caeté blocks, Baltazar and Zucchetti (2007) unified them due to their lithologic similarities. Herein we adopt the latter proposal, which subdivides the RVGB into the Santa Bárbara (SB), Nova Lima-Caeté (NLC), and São Bartolomeu (SBT) blocks (Table 1, Figs. 2A, 2B). Rock units of the SB block have a NE-SW trend, with gentle to moderate dip towards SE. In the SBT block and the southern sector of the NLC block, the layers have a general NW-SE trend, dipping towards NE, except for the Andaimes Syncline that presents a discordant E-W trend. In the north sector of the NLC block, the rock units are folded with an axial plane NE-SW, with dip towards SE, and are obliterated by a large E-W striking transcurrent faults system (Lobato et al. 2001a).

The SB block occurs in the eastern portion of the QF (Figs . 2A, 2B). It comprises the Archean Rio das Velhas Supergroup subdivided, from base to top, into the Quebra Osso, Nova Lima, and Maquiné groups (Table 1, Fig. 3), under greenschist to lower amphibolite facies metamorphism. The Quebra Osso Group comprises mostly metakomatiites. The Nova Lima Group consists of tholeiitic metabasalts, and clasto-chemical metasedimentary rocks of the Vigário da Vara, Santa Quitéria and Córrego do Sítio formations. The Maquiné Group is made up of siliciclastic metasedimentary rocks of the Palmital and Casa Forte formations. The succession is stratigraphically overturned, and the Santa Bárbara Complex tectonically overrides the eastern border of the greenstone belt sequence (Fig. 2A). On the western side, the contact of the RVGB with the metasedimentary sequences of the NeoarcheanPaleoproterozoic Minas Supergroup is also a thrust-fault. This 


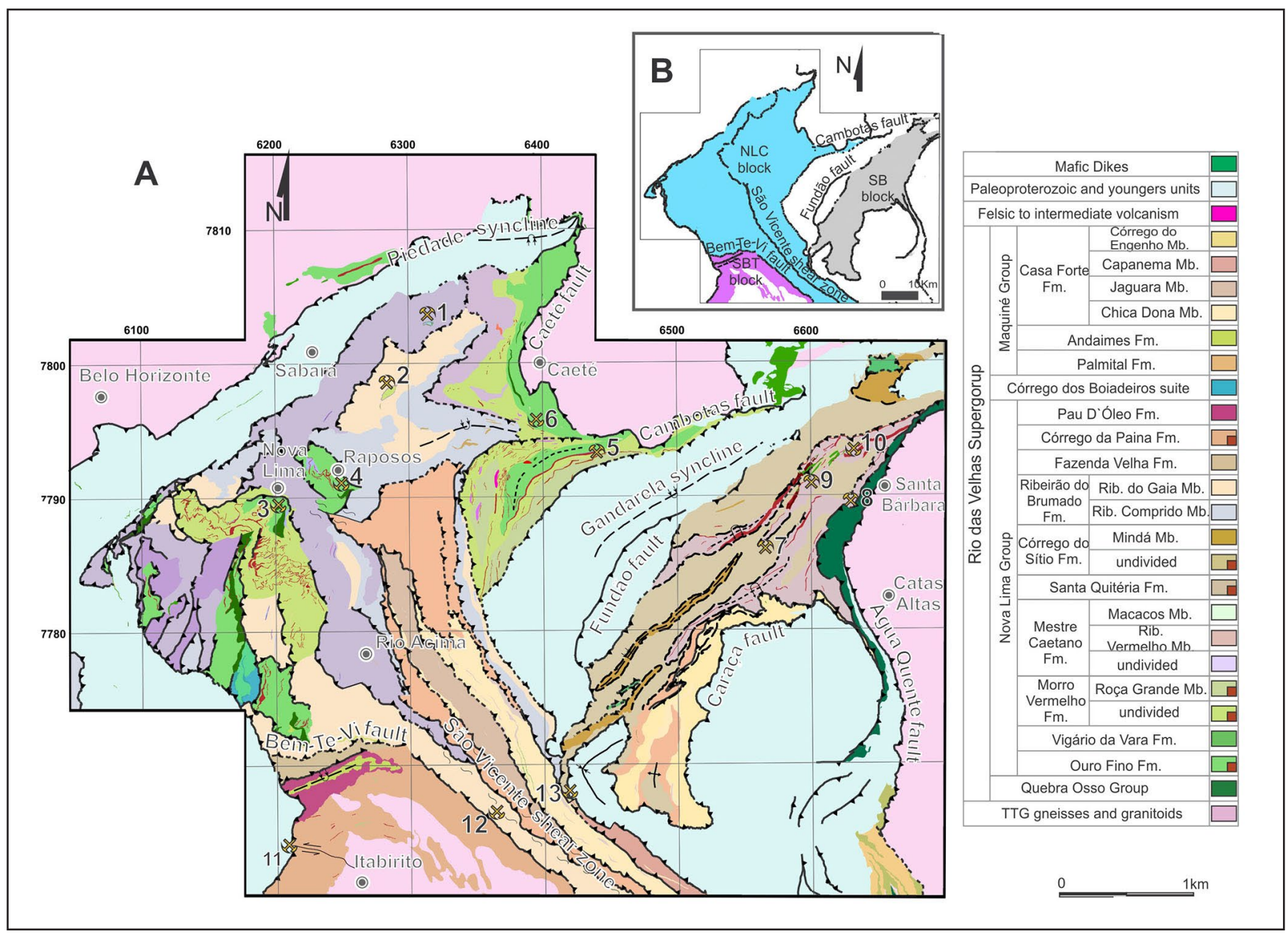

FIGURE 2. A) Simplified geological map of the northern portion of the Quadrilátero Ferrifero. The tectonostratigraphic domains are marked in Figure 1C. Gold deposits: 1- Cuiabá; 2- Lamego; 3- Morro Velho; 4- Raposos; 5- Roça Grande; 6- Juca Vieira; 7- Córrego do Sítio l; 8- Pilar; 9- Córrego do Sítio II (former São Bento); 10- Santa Quitéria; 11- Cata Branca; 12- Santa Izabel (Paciência complex); 13- Ouro Fino. B) Simplified map showing the main faults and shear zones that were used to limit the RVGB into three tectonostratigraphic blocks, according to Baltazar and Zucchetti (2007).

TABLE 1. Stratigraphic nomenclature for the Nova Lima-Caeté, Santa Bárbara, and São Bartolomeu tectonostratigraphic blocks of the Rio das Velhas greenstone belt. The vertical separation between the blocks does not imply a linear age relationship between the units, although the stacking units do imply younging of strata from the bottom to top.

\begin{tabular}{|c|c|c|c|c|c|c|c|}
\hline \multicolumn{8}{|c|}{ Rio das Velhas Supergroup } \\
\hline \multicolumn{3}{|c|}{ Santa Bárbara block } & \multicolumn{3}{|c|}{ Nova Lima - Caeté block } & \multicolumn{2}{|c|}{ São Bartolomeu block } \\
\hline \multirow{4}{*}{$\begin{array}{l}\text { Maquiné } \\
\text { Group }\end{array}$} & \multirow{3}{*}{ Casa Forte Fm. } & \multirow{2}{*}{$\begin{array}{l}\text { Córrego do } \\
\text { Engenho Mb. }\end{array}$} & \multirow{4}{*}{$\begin{array}{l}\text { Maquiné } \\
\text { Group }\end{array}$} & \multirow{3}{*}{ Casa Forte Fm. } & Capanema Mb. & \multirow{4}{*}{$\begin{array}{l}\text { Maquiné } \\
\text { Group }\end{array}$} & \\
\hline & & & & & Jaguara Mb. & & \\
\hline & & Chica Dona Mb. & & & Chica Dona Mb. & & \\
\hline & Palmital Fm. & & & Palmital Fm. & & & Andaimes Fm. \\
\hline \multirow{8}{*}{$\begin{array}{c}\text { Nova Lima } \\
\text { Group }\end{array}$} & \multirow{2}{*}{$\begin{array}{l}\text { Córrego do } \\
\text { Sítio Fm. }\end{array}$} & Mindá Mb. & \multirow{8}{*}{$\begin{array}{c}\text { Nova Lima } \\
\text { Group }\end{array}$} & \multirow{2}{*}{$\begin{array}{l}\text { Ribeirão do } \\
\text { Brumado Fm. }\end{array}$} & Ribeirão do Gaia Mb. & \multirow{8}{*}{$\begin{array}{c}\text { Nova Lima } \\
\text { Group }\end{array}$} & Pau D'Óleo Fm. \\
\hline & & Undivided & & & Ribeirão Comprido Mb. & & $\begin{array}{c}\text { Córrego da Paina } \\
\text { Fm. }\end{array}$ \\
\hline & \multirow{6}{*}{$\begin{array}{c}\text { Vigário da Vara } \\
\text { Fm. }\end{array}$} & \multirow{3}{*}{ Undivided } & & \multirow{3}{*}{$\begin{array}{c}\text { Mestre Caetano } \\
\text { Fm. }\end{array}$} & Macacos Mb. & & Fazenda Velha Fm. \\
\hline & & & & & Undivided & & \\
\hline & & & & & Ribeirão Vermelho Mb. & & \\
\hline & & \multirow{3}{*}{ Undivided } & & \multirow{2}{*}{$\begin{array}{c}\text { Morro Vermelho } \\
\text { Fm. }\end{array}$} & Roça Grande Mb. & & \\
\hline & & & & & Undivided & & \\
\hline & & & & Ouro Fino Fm. & Undivided & & \\
\hline $\begin{array}{c}\text { Quebra } \\
\text { Osso } \\
\text { Group }\end{array}$ & \multicolumn{2}{|c|}{ Undivided } & & & & & \\
\hline
\end{tabular}


block comprises important gold deposits (e.g., Córrego do Sítio, and Pilar; Fig. 2A), mainly distributed along the NE-SW trending Córrego do Sítio Lineament (Porto 2008; Lima 2012; Roncato et al. 2015). The contact of the SB block with the NLC block is represented by the Fundão-Cambotas fault system and the São Vicente shear zone (Fig. 2B).

The NLC block occurs at the central portion of the QF (Figs. 2A, 2B), surrounded by the Minas Supergroup to the north, west, and southeast, and by the Caeté Complex to the east. This is the only block of the RVGB containing a complete greenstone belt sequence. It comprises tholeiitic and komatiitic metabasalts and chemical sedimentary rocks (Ouro Fino and Morro Vermelho formations), followed by volcaniclastic and epiclastic marine metasedimentary rocks (Mestre Caetano and Ribeirão do Brumado formations) of the Nova Lima Group (Table 1, Fig. 3). The top sequence of the belt consists of medium to coarsegrained clastic metasedimentary rocks of the Maquiné Group (Palmital and Casa Forte formations), of greenschist facies. This block has a great economic interest because it contains the active and historical major gold deposits of the QF, including two world-class mines (Cuiabá and Morro Velho; Fig. 2A), as well as large to small deposits (Lamego, Raposos, Roça Grande and Juca Vieira (see Lobato et al. $2001 \mathrm{~b}$ for details). The southwestern contacts between the NLC and the SBT blocks are the Bem-Te-Vi thrust fault and the São Vicente shear zone (Fig. 2B).

The SBT block, located in the southern portion of the QF (Figs. 2A, 2B), is limited, to the south and west, by the Minas Supergroup. Only the northern part of the block underwent detailed study during this stage of the Quadrilátero Ferrífero project. The southern part of the block, which contains its most representative rocks, belongs to the project's next stages. The studied part of the block consists of clastic rocks arranged in greywacke-argillite cycles ascribed to the Nova Lima Group (Fazenda Velha, Córrego da Paina, and Pau D'Óleo formations; Table 1, Fig. 3), and quartz-rich metasedimentary rocks of the Maquiné Group (Andaimes Formation). The metamorphic grade of its rocks reached amphibolite facies. Gold mineralization in the block are restricted and comprise the deposits that occur in contact with the Minas Supergroup (Cata Branca Mine) and along the São Vicente shear zone (Paciência Mine).

As in most worldwide greenstone belts, the stratigraphic framework of the RVGB includes rocks of distinct nature and composition that are repeatedly interbedded (Fig. 3). Therefore, geologic mapping in these terrains must rely on the distinction and individualization of prevailing lithotypes and their associations. In this context, different formations may contain similar lithotypes but differ in relative abundance.

\section{Stratigraphy of the Rio das Velhas Greenstone Belt}

\subsection{Quebra Osso Group}

The Quebra Osso Group is the lowest stratigraphic unit of the RVGB. The type-area of the Group is located in the eastern portion of the Santa Bárbara block, east of the Catas Altas and Santa Bárbara quadrangles (Fig. 1C; Ferreira et al. 2020 a, c). It crops out as an NNE-SSW $\sim 15-\mathrm{km}$ long and $\sim 0.5-1.5-\mathrm{km}$ wide strip of land, which occurs along the homonymous river. The contact with the TTGs of the Santa Bárbara Complex and the metasedimentary rocks of Minas Supergroup, to the east, and metavolcano-sedimentary rocks of the Nova Lima Group, to the west, are marked by thrust-faults.

Harder and Chamberlain (1915) presented the first description of the unit as serpentinized eruptive rocks, whereas Simmons (1968) and Maxwell (1972) interpreted it as intrusive ultrabasic rocks of the Nova Lima Group. Schorscher $(1978,1979)$ described these rocks as peridotitic komatiites, and proposed the term Quebra Osso Group, placing it below the Nova Lima and Maquiné groups. Although Baltazar and Raposo (1993) and Zucchetti and Baltazar (2000) maintained these rocks at the base of the Nova Lima Group, herein we follow the stratigraphic hierarchy proposed by Schorscher (1979). In contrast to the Nova Lima Group, the Quebra Osso Group is mainly constituted by komatiites without association with basalts, and displays numerous outcrops with preserved volcanic features, including the characteristic spinifex texture.

The lava flows sequence of the Group is well exposed in serpentinite inactive quarries of the Pedreira Um Valemix (Fig. 4A). They were briefly described in previous works (Schorscher et al. 1990; Schorscher 1992; Sichel 1983; Sichel and Valença 1983; Schrank et al. 1984, 1990; Santos 2011; Acken et al. 2016; Verma et al. 2017), and Ferreira et al. (2020e) present a comprehensive study about its volcanic architecture and petrogenesis. The flows are massive to brecciated, with subordinate spinifex-textured komatiites, pillow lavas, and minor metavolcaniclastic rocks (Figs. 4B, 4C, 4E). The metakomatiites are green to darkgrey, fine to medium-grained serpentinites and ultrabasic schists, commonly crosscut by veins of fibrous serpentine or carbonate. The primary mineral association comprises olivine and pyroxene, which were completely replaced by variable proportions of serpentine, magnetite, tremolite, talc and chlorite. Mg-carbonate, ilmenite, chromite, pyrrhotite, and pentlandite occur as traces. Despite the pervasive alteration of the protoliths, the primary textures are commonly preserved as pseudomorphic serpentine and/or chlorite. The majority of massive flows correspond to meso to orthocumulates, in which granular olivine was replaced by mesh-textured serpentine (Fig. 4D). Spinifextextured exposures contain pseudomorphs of large skeletal tabular olivine and acicular pyroxene (Fig. 4E), replaced by serpentine and/or chlorite, set in a fine-grained matrix of tremolite + chlorite + serpentine + opaque phases (Fig. 4F).

The contacts between the lava flows are in general sheared, and the thickness of the volcanic successions is uncertain. In some regions, these volcanic rocks underwent an intense deformation, with the complete destruction of the primary features. The most foliated exposures comprise tremolitites, serpentine-talc schists, and talc-serpentine-tremolite-(biotite)-(chlorite) schists. They display nematoblastic and lepidoblastic textures, defined by oriented prismatic tremolite and flakes of phyllosilicates. Minor mineral phases comprise quartz, plagioclase, magnetite, titanite, phlogopite, and epidote. The contacts between this unit and the TTG are marked by alteration zones represented by chloritites ("blackwall”), tourmaline-chlorite schists and phlogopitites. Rare lenses of metasedimentary rocks, such as BIF, metachert, carbonaceous phyllite, and fuchsite-quartz schist occur interbedded with the ultrabasic lava flows. 


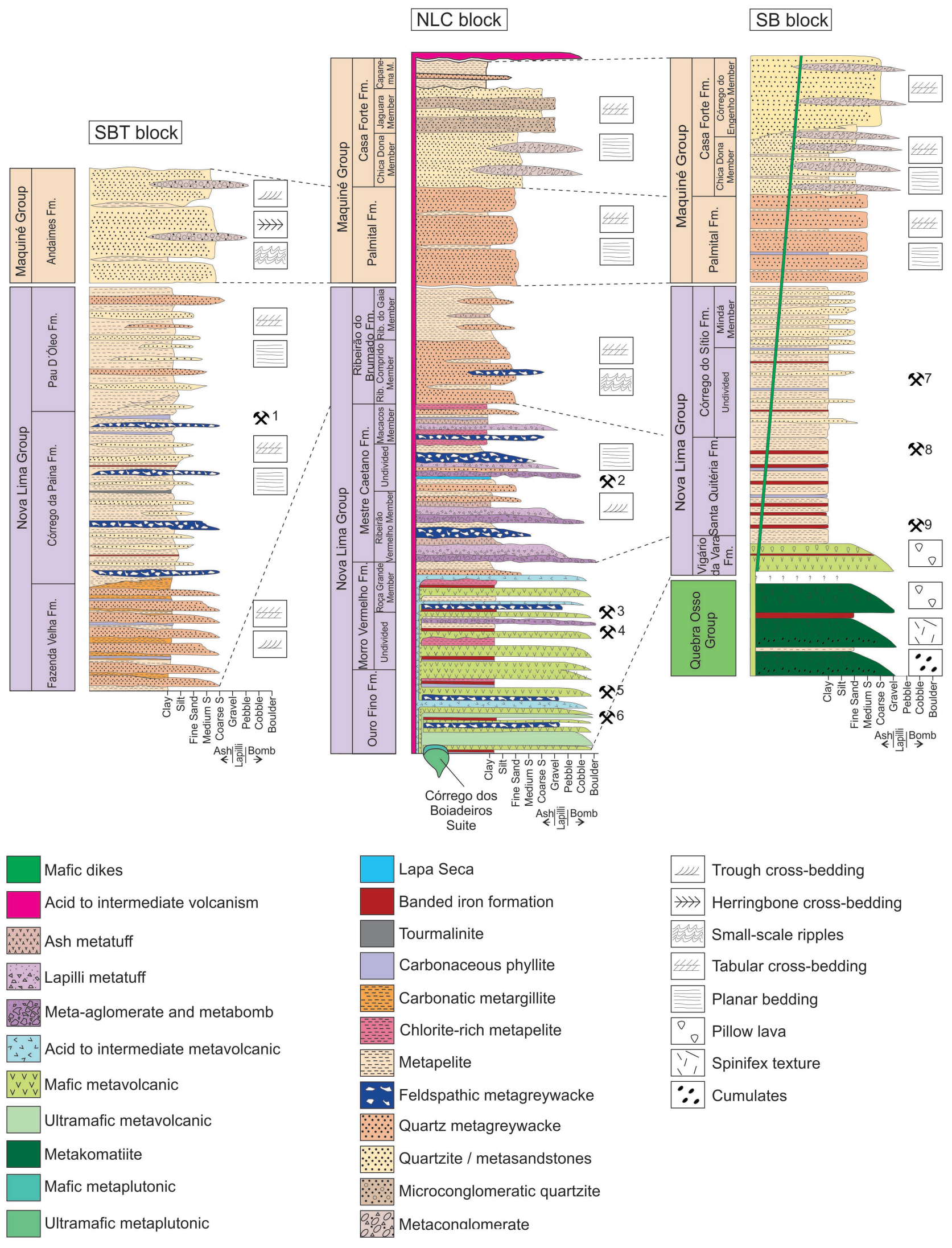

FIGURE 3. Stratigraphic columns of the three tectonostratigraphic blocks of the Rio das Velhas greenstone belt. The figure does not represent the thickness of the layers, nor does vertical separation imply a linear temporal relationship. Gold deposits: 1- Santa Izabel (Paciência complex), Ouro Fino and Cata Branca; 2- Morro Velho; 3- Roça Grande; 4- Cuiabá and Lamego; 5- Juca Vieira; 6- Raposos; 7- Córrego do Sítio; 8- Santa Quitéria; 9- Pilar. 

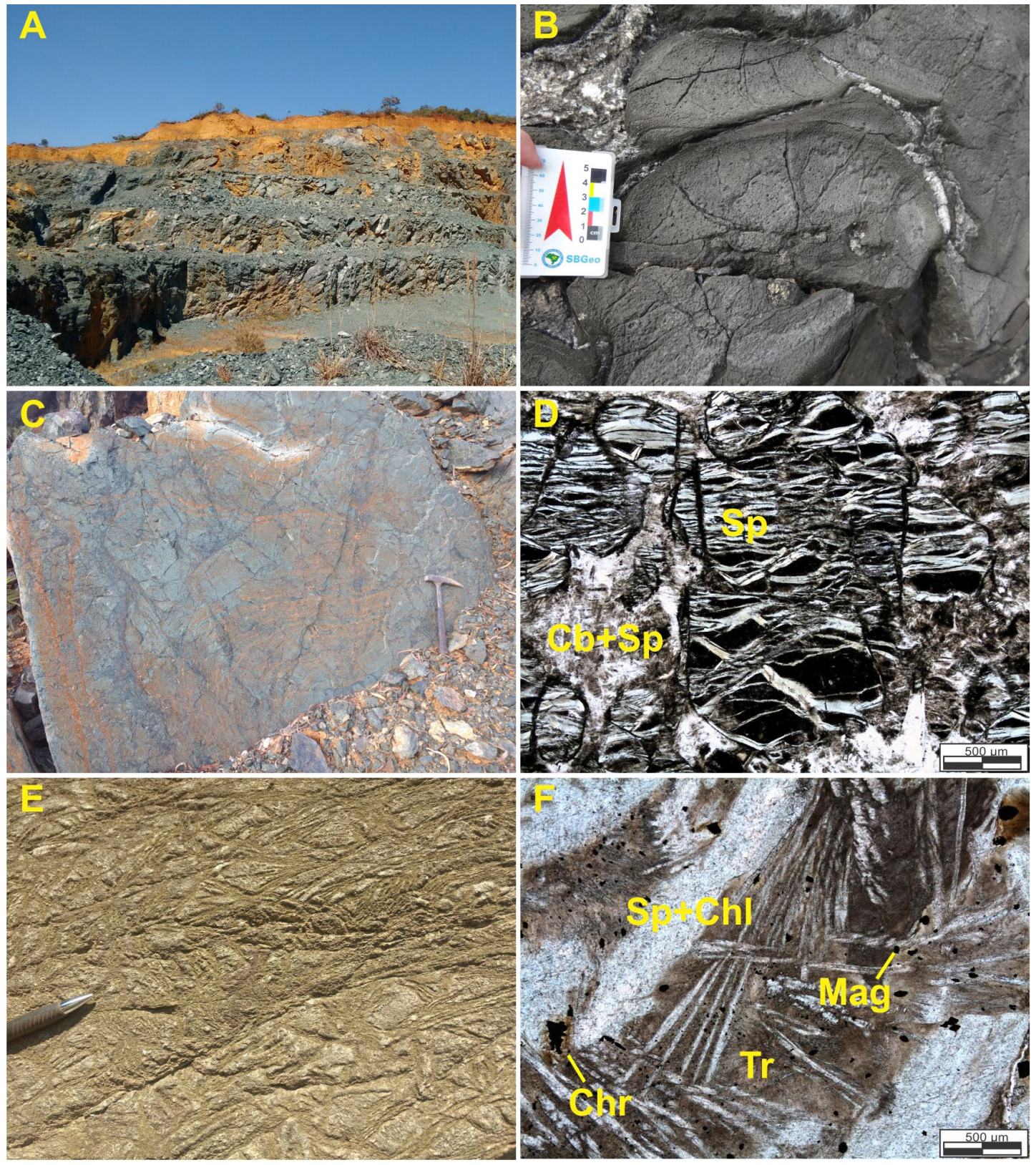

FIGURE 4. Quebra Osso Group. (A) - Serpentinite quarry (Pedreira Um Valemix) of the Quebra Osso Group type-area. (B) - Pillowed lava-flow with concentric zoning and radial fractures. (C) - Massive to brecciated metakomatiite. (D) - Cumulate texture given by granular pseudomorphic serpentine after olivine, with mesh texture (thin section in plane-polarized light, PPL). (E) - Spinifex-textured flow, illustrated by the thin section of $(F)$ - Pseudomorphic serpentine formed after platy olivine and pyroxene (PPL). Abbreviations: $\mathrm{Cb}=$ carbonate; $\mathrm{Sp}=$ serpentine; $\mathrm{Chl}=\mathrm{chlorite}$; Mag = magnetite; $\mathrm{Chr}=$ chromite; $\mathrm{Tr}=$ tremolite.

\subsection{Nova Lima Group}

\subsubsection{Nova Lima Group in the SB block}

In the SB block, the Nova Lima Group comprises three formal units that are, from base to top, Vigário da Vara, Santa Quitéria and Córrego do Sítio formations.

\subsubsection{Vigário da Vara Formation}

The Vigário da Vara Formation occurs as NE-SW tectonic slivers within the Nova Lima Group's metavolcanosedimentary sequences. The type-area of Vigário da Vara Formation occurs at the homonymous locality, along the margins of the Conceição River, south of Conceição do Rio Acima quadrangle (Fig. 1C; Ferreira et al. 2020b). It also outcrops in the northeast part of the SB block, north of the Santa Bárbara quadrangle (Ferreira et al. 2020c). This formation was previously considered as a part of the Ouro Fino Unit (Silva and Zucchetti 1993), exposed in the NLC block, which contains a similar basic metavolcanic rock association at the base of the Nova Lima Group. Despite the similar geochemical patterns of the basic rocks of both the NLC and the SB blocks reported by Zucchetti (1998), Zucchetti et al. (2000a), and Baltazar and Zucchetti (2007), detailed studies are still required to understand their respective magma sources and crystallization ages, to support the correlation between both Vigário da Vara and Ouro Fino formations. We 
herein maintain the basic metavolcanic rocks of the SB block as a separate unit.

This unit consists of tholeiitic metabasalts with locally preserved original igneous features, such as pillowed lava flows (Fig. 5A) and amygdala (Fig. 5B). However, the lavas underwent deformation and stretching along the metamorphic foliation. The metabasalts also contain rare intercalations of centimetric lenses of BIF and metachert (Fig. 5C).

The basic metavolcanic rocks are green to grey, massive to foliate, and very fine-grained to aphanitic. The original basic lavas underwent a metamorphic transformation into tremolites, actinolitites, albite-chlorite-tremolite/actinolite schists, tremolite/actinolite schists, quartz-chlorite schists, and albite-quartz-mica schists. Minor phases include epidote, titanite, opaque minerals, quartz, tourmaline, and rutile. The amphiboles are the main component of the samples' matrix and may form radial fibrous aggregates that resemble quench texture (Fig. 5D). Albite occurs mostly as tabular relict phenocrysts with Carlsbad twinning and evidence of corrosion (Fig. 5E). When present, amygdales have a 0.1-0.3 $\mathrm{mm}$ diameter, and are often concentrically filled with quartz, chlorite, epidote, and opaque phases (Fig. 5F).

\subsubsection{Santa Quitéria Formation}

The Santa Quitéria Formation crops out in the central portion of the Catas Altas, Conceição do Rio Acima, and Santa Bárbara quadrangles, along the NE-SW-trending
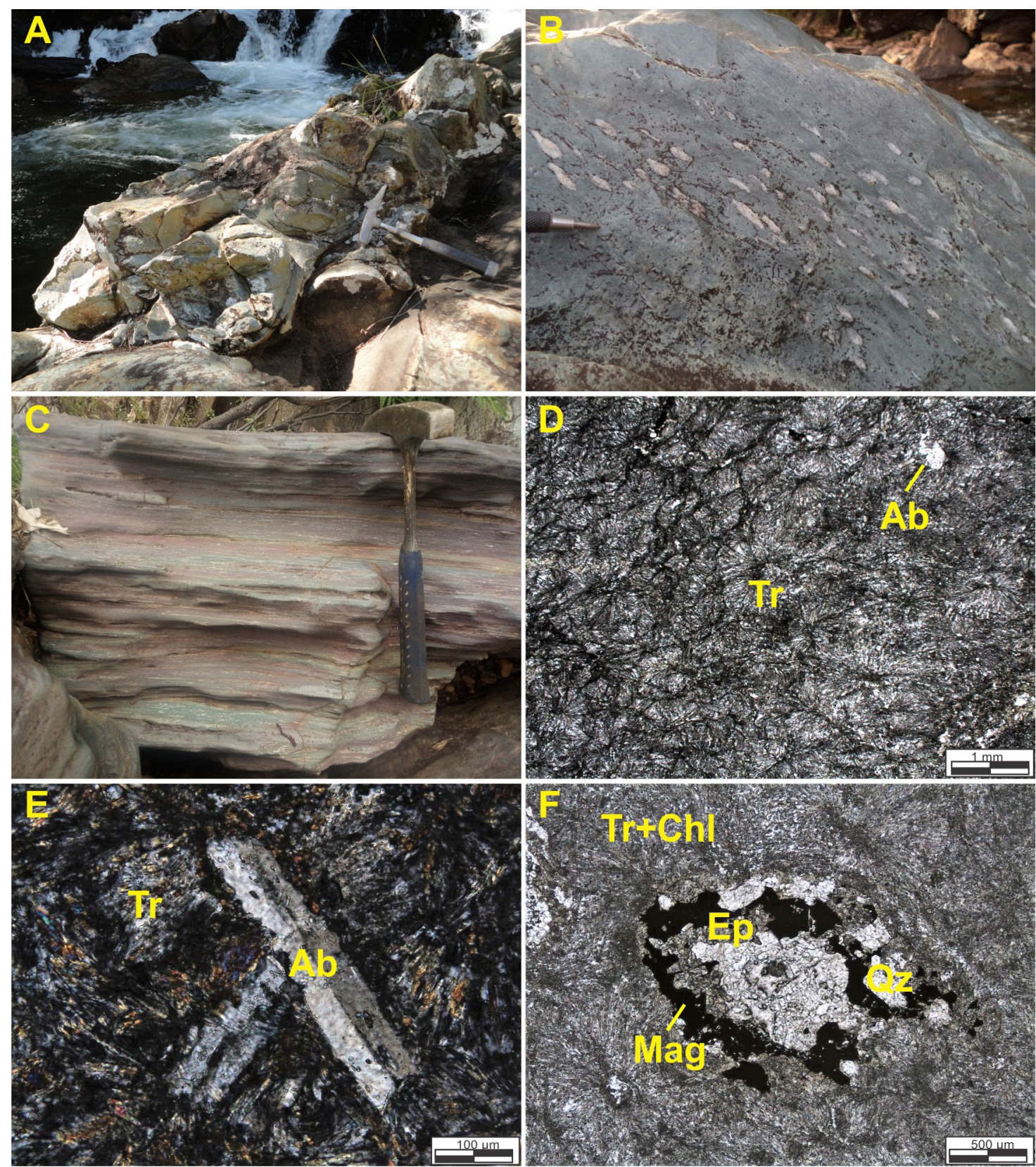

FIGURE 5. Vigário da Vara Formation metabasalts. (A) - Outcrop with pillows. (B) - Outcrop with amygdales. (C) - Centimetric layers of banded iron formation interlayered with massive metabasalt. (D) - Photomicrography of tremolitite with quench texture (PPL). (E) - Photomicrography of Carlsbad twinned albite phenocrysts, with evidence of corrosion (cross-polarized light, CPL). (F) - Photomicrography of chlorite-tremolite schist with concentric filling with quartz, magnetite, and epidote amygdale (PPL). Abbreviations: $\mathrm{Tr}=$ tremolite, $\mathrm{Ab}=\mathrm{albite}, \mathrm{Chl}=\mathrm{chlorite}, \mathrm{Qz}$ = quartz, Mag = magnetite, $\mathrm{Ep}=$ epidote. 
Conceição River (Ferreira et al. 2020a, b, c). Its type-area is located in the historical Santa Quiteria gold mine region, near the city of Santa Bárbara. The contact with the metavolcanic rocks of the Quebra Osso Group is a thrust-fault, and the overlying Córrego do Sítio Formation and Maquiné Group are transitional and tectonic, respectively.

This formation comprises the clasto-chemical metasedimentary sequences of the Nova Lima Group (Silva 1996). It consists of a thick sequence of metapelites, carbonaceous phyllites, banded iron formations, and metachert, often crosscut by quartz-carbonate veins (Figs. $6 \mathrm{~A}, 6 \mathrm{~B})$. Rocks of this sequence are pervasively foliated and the presence of tight to isoclinal folds (Fig. 6C), suggests that the unit is probably thickened by tectonic repetition. The metapelites are laminated, with millimetric layers of variable composition and color. However, they are commonly deeply weathered. Fresh outcrops comprise mica-quartz schists, (carbonate)-(chlorite)-sericite-quartz schists and chlorite schists. Under the microscope (Fig. 6D), they are very fine-gained containing minor proportions of biotite, titanite, epidote, and pyrite. The carbonaceous phyllites are black to dark grey and composed of quartz, sericite, chlorite, and carbonaceous matter.

The chemical metasedimentary rocks comprise banded iron formation (BIF) and metachert. The thickness of the BIF ranges from a few centimeters $(\mathrm{cm})$ to a few tens of meters $(\mathrm{m})$ of alternating $\mathrm{mm}$ - to $\mathrm{cm}$-thick bands of hematite-magnetite aggregates with minor proportions of recrystallized chert (Figs. 6E, 6F). Sericite, chlorite, chalcopyrite, pyrite, epidote, and tourmaline may occur as trace phases. The BIFs host substantial orogenic gold deposits, such as the São Bento (AngloGold Ashanti) and Pilar (formerly Brumal, Jaguar Mining). The ore-zones comprise massive or disseminated arsenopyrite and pyrrhotite, crosscut by quartz-carbonatesulfide veins (Valladares 2004; Martins Pereira 2007; Silva 2007; Guerrero 2016).

\subsubsection{Córrego do Sítio Formation}

The Córrego do Sítio Formation is largely distributed in the Santa Bárbara block and its main exposures occur in the homonymous gold mine. This formation consists of metasedimentary rocks trending NE-SW, formerly interpreted as a part of the resedimented lithofacies association described by Baltazar and Zucchetti (2007).

It comprises a rhythmic sequence with cycles of metapsammite, metapelite, and carbonaceous metapelite (see Fig. 3). Banded iron formations are rare. The cycles are $\mathrm{cm}$ - to $\mathrm{dm}$-thick (Fig. $7 \mathrm{~A}$ ) and rest on sharp to erosive contact with the top of the underlying cycle. They display upright facing given by gradual upward decrease of grainsize to the upper layers of carbonaceous metapelite (Figs. 7A, 7B). Several works report that the cycles correspond to incomplete Bouma (1962) divisions (Zucchetti et al. 2000c; Baltazar and Zucchetti 2007; Roncato et al. 2015; Sepulveda 2020), and the internal rock arrangement of this formation indicates that it represents a distal turbidite sequence. The rocks of the successions are foliated and often overprinted by hydrothermal alteration zones containing carbonate, sericite, quartz, and sulfides (Fig. 7C).

The metapelites correspond to very fine-grained (chlorite)sericite-quartz schists. They have plane-parallel bedding defined by an alternation of $\mathrm{mm}$ to $\mathrm{cm}$ - bands of polygonal quartz and oriented phyllosilicates (Fig. 7D). These rocks contain variable amounts of carbonaceous matter and traces of rutile, chloritoid, zircon, opaques, and carbonate.

The psammitic layers are fine- to coarse-grained metagreywackes composed of alternating layers of quartz \pm albite and sericite + chlorite (Fig. 7E). Quartz occurs as rounded to stretched porphyroclasts (Fig. 7F), displaying recrystallization, such as subgrains and undulating extinction.

The Córrego do Sítio Formation hosts important gold deposits spread along a regional NE-SW Córrego do Sítio Lineament (Porto 2008; Lima 2012), such as Cachorro Bravo, Carvoaria, Laranjeiras, Cristina, Rosalino, and Grota Funda deposits. The orebodies consist either of disseminated arsenopyrite, pyrite, chalcopyrite, pyrrhotite, stibnite and berthierite, or quartz-carbonate sulfide \pm sulfosalts veins (Roncato et al. 2015 and references therein).

\subsection{Mindá Member}

Metapsammites often occur within the typical metaturbidites of the Córrego do Sítio Formation, but they significantly prevail over the metapelites in some localities. The metapsammites were previously grouped in an informal and independent unit called Mindá (Silva 1996; Zucchetti et al. 2000c). However, the geological mapping carried out during this study recognized remarkable similarities between these rocks, and those of the Córrego do Sítio Formation. Therefore, we suggest that the Mindá unit is merely a coarse-grained member of this formation (Fig. 7G). The type area of the Mindá Member is located near the Peti Dam, in the northern part of the Santa Bárbara block. It also occurs as NE-SW-trending lenses within the Córrego do Sítio Formation in the Catas Altas, and Conceição do Rio Acima quadrangles (Ferreira et al. 2020a, b).

This unit includes (plagioclase)-(chlorite)-sericite-quartz schists. Compositional layering is usually present and characterized by alternating millimeter-thick lamina composed of polygonal quartz \pm albite aggregates and phyllosilicates stringers (Fig. 7H). Quartz and plagioclase occur as angular to sub-rounded porphyroclasts set in a chlorite, sericite, and rare biotite matrix. Porphyroclasts are often present and stretched parallel to the foliation. Tourmaline, titanite, rutile, biotite, zircon, and opaque minerals are minor phases.

\subsubsection{Nova Lima Group in the NLC block}

The Nova Lima Group that outcrops in the Nova LimaCaete block is here divided into four formal units named Ouro Fino, Morro Vermelho, Mestre Caetano, and Ribeirão do Brumado formations.

\subsubsection{Ouro Fino Formation}

The Ouro Fino Formation is the basal unit of the Nova Lima Group, and it was first defined as an informal unit by CPRM (1996). It occurs in two main areas. One at the eastern margin of the block, where it crops out as a continuous layer in tectonic contact with granodioritic rocks of the TTG basement. Another, in the Nova Lima region, central-western part of the block, surrounded by the youngest rocks of the Nova Lima Group in tectonic or transitional contact (Fig. 2A). The most representative outcrops of this formation occur in the Juca 
Vieira and Caeté streams, and along the BR-262 road, to the west of the city of Caeté, in the Caeté quadrangle (Araújo et al. 2020a), in the Ouro Fino farm, in the Serra da Piedade quadrangle (Araújo et al. 2020d), and in the Peixe River, southwestern sector of the Rio Acima quadrangle (Cavalcanti et al. 2020c). It also occurs in the Gandarela, Gongo Soco, Belo Horizonte, Nova Lima, Santa Luzia, São Sebastião das Águas Claras and Itabirito quadrangles (Fig. 1C; Araújo et al. 2020b, c; Cavalcanti et al. 2020a, b, d, e; Freitas et al. 2020b).

The formation comprises basic metavolcanic rocks with interlayered ultrabasic and acid metavolcanic and metavolcaniclastic rocks. Subordinate occurrences comprise intermediate volcanic rocks, banded iron formations (BIF), metachert, carbonaceous metapelite, and other pelagic sedimentary protoliths (Fig. 3).

The most common rocks of this assemblage are serpentinites (Figs. 8A, 8B), tremolitites, and serpentinetremolite-chlorite schists, talc schists, and quartz-carbonatechlorite schists (Figs. 8C, 8D). The least altered rocks are green to dark green, fine- to medium-grained, and are massive or schistose. The serpentinites may contain hexagonal-shaped, 0.3 to $2 \mathrm{~mm}$ serpentine pseudomorphs (Fig. 8B), probably derived from cumulate olivine crystals. Original features like pillows occur locally (Figs. 8A, 8C). Talc schists occur in layers up to $100 \mathrm{~m}$ thick in the western portion of the block. However, most outcrops are deeply weathered to brown, massive chlorite, clay minerals, quartz, and carbonate. In shear zones, due to the intense deformation, tectonic banding may be
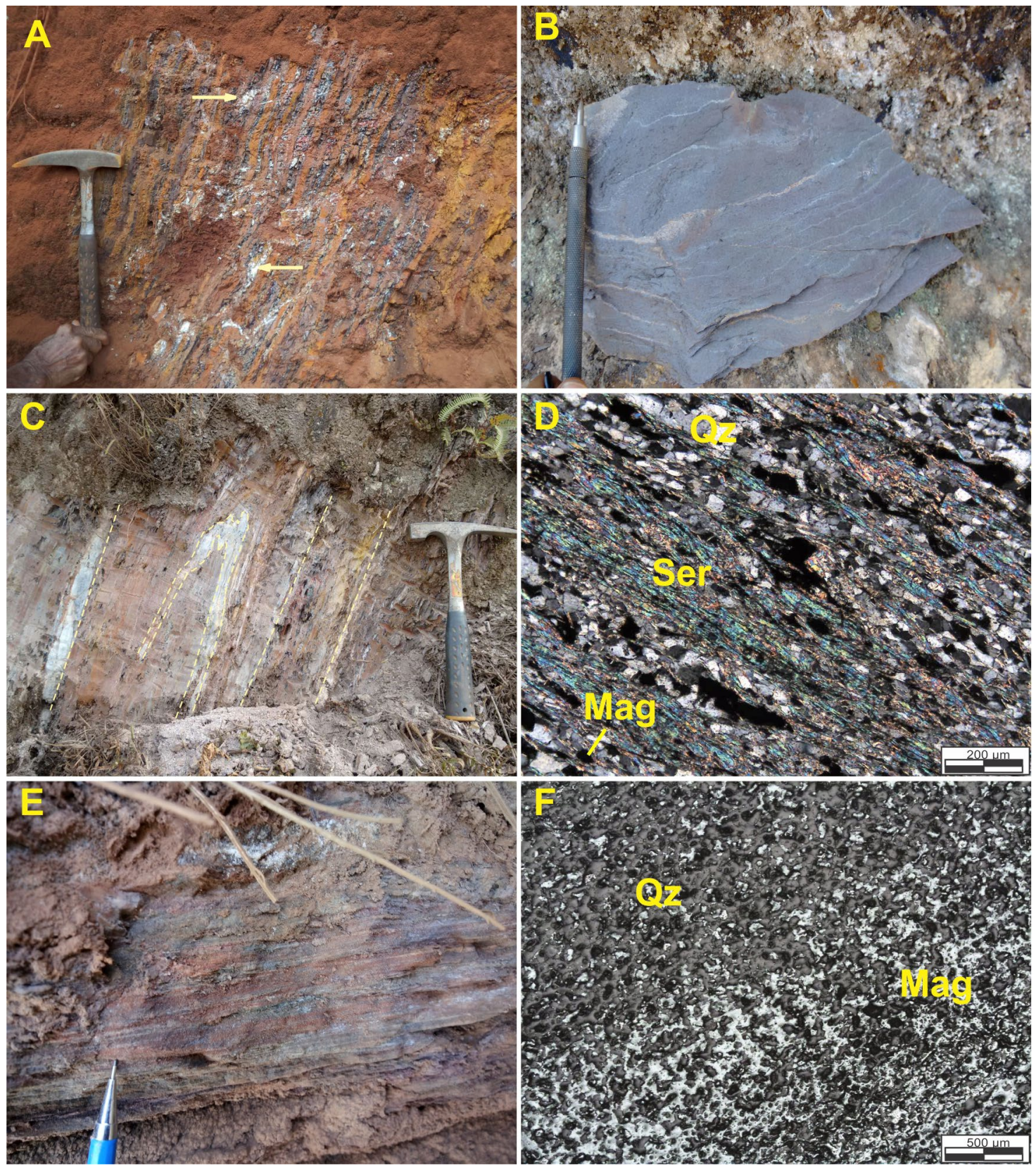

FIGURE 6. Santa Quitéria Formation. (A) - Outcrop of metapelites interbedded with cm-thick BIF cut by quartz and carbonate veins indicated by yellow arrows. (B) - Hand sample of dark grey carbonaceous phyllite. (C) - Outcrop showing alternating layers of laminated and tight-folded metapelite of various composition and color (dashed lines mark the foliation and an intrafolial fold). (D) - Thin section of muscovite-quartz schist (CPL). (E) - Outcrop of BIF with centimetric layering given by alternating bands rich in quartz and magnetite. (F) - Thin section of a magnetiterich banded iron formation (reflected light, RL). Abbreviations: $Q z=$ quartz, Ser = white mica, Mag = magnetite. 

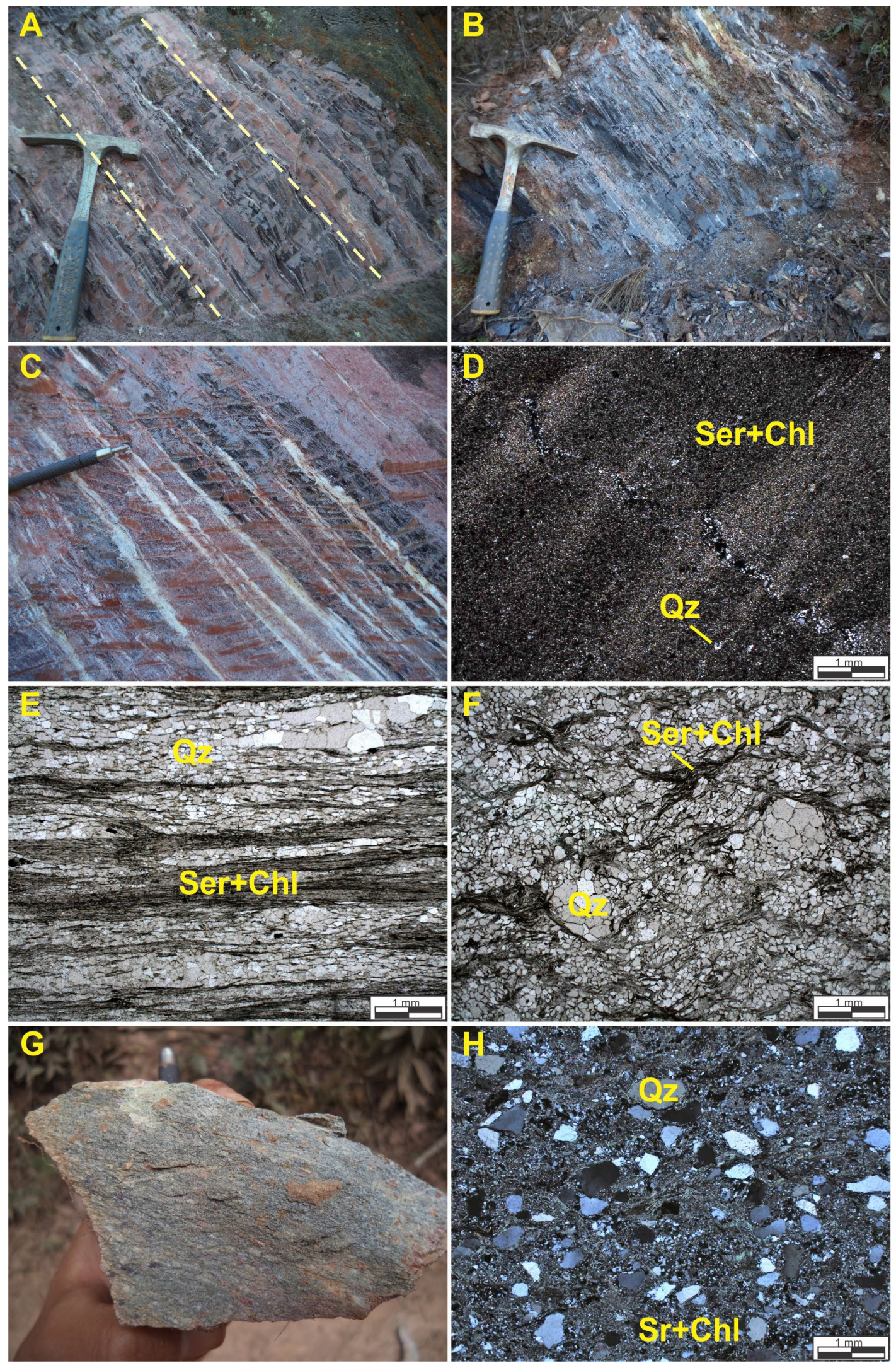

FIGURE 7. Córrego do Sítio Formation. (A) - Outcrop of metarhythmite with plane-parallel bedding; dashed lines mark the lower and the upper limits of one sedimentary cycle composed of a basal metapsammite and an upper layer of carbonaceous metapelite. Facing is from left to right. (B) - Outcrop of carbonaceous phyllite. (C) - Outcrop of a turbidite with white centimetric quartz-carbonate veins parallel to the bedding. (D) - Photomicrography of a thin-section of metapelite composed of a sericite and chlorite groundmass with traces of very fine-grained quartz (PPL). (E) - Photomicrography of a thin-section of very fine-grained laminated metagreywacke (PPL). (F) - Photomicrography of a thin-section of the Mindá Member metagreywacke composed of an aggregate of rounded polycrystalline quartz porphyroclasts and stringers of chlorite and sericite (PPL). (G) - Hand-sample of a Mindá Member metapsammite with quartz granules. $(\mathrm{H})$ - Photomicrography of a thin-section of the Mindá Member metagreywacke with irregular to triangular quartz porphyroclasts in a micaceous matrix $(\mathrm{CPL})$. Abbreviations: $\mathrm{Ser}=$ sericite, $\mathrm{Chl}=$ chlorite, $\mathrm{Qz}=$ quartz, $\mathrm{Ab}=$ albite . 
present, alternating chlorite-rich and thin quartz-rich bands.

Acid to intermediate metavolcanic and metavolcaniclastic rocks commonly occur intercalated with basic rocks. They consist of sericite-quartz schists and sericite-plagioclasequartz schists. The metavolcaniclastic rocks occur as feldspathic metagreywackes that frequently host fragments of volcanic rocks. Porphyroclasts of grayish-blue quartz and white plagioclase are common (Figs. 8E, 8F). Quartz commonly presents corrosion gulfs (Fig. 8F) or bipyramidal shapes, whereas plagioclase can be compositionally zoned. These rocks underwent intense metasomatic alteration and submitted to multiple episodes of deformation and metamorphism. Because of that, primary features are often obliterated, and it is no longer possible to distinguish between volcanic and volcaniclastic rocks, the reason they are here described together.

BIF and metachert are less common rocks of the Ouro Fino Formation and occur more frequently in the Nova Lima region (Fig. 2A). BIF is usually oxidized, with quartz leaching, they are rich in iron oxi-hydroxides. Banding may be preserved, and given by quartz-rich layers in alternation with layers rich in goethite, magnetite and hematite. Metachert commonly occurs as thin layers of quartz interbedded with the ultrabasic/ basic metavolcanic rocks. Quartz- and sericite-bearing carbonaceous phyllite is frequently associated with BIF.

To the southeast of the city of Caeté, rocks with unusual composition occur near the Ouro Fino Formation tectonic contact with granitic rocks of the Caete Complex. One is a melanocratic, fine- to medium-grained ultramafic rock (Fig. $8 \mathrm{G}$ ), with cordierite, anthophyllite, quartz (Fig. $8 \mathrm{H}$ ), and subordinate plagioclase, phlogopite, and garnet. Despite its local occurrence, Silva et al. (1995) argue about the possible geotectonic and metallogenetic significance of these rocks. This paragenesis indicates enrichment in $\mathrm{Al}_{2} \mathrm{O}_{3}, \mathrm{SiO}_{2}, \mathrm{TiO}_{2}$, and depletion of $\mathrm{MgO}, \mathrm{Ni}$, Co when compared to other ultramafic rocks of the same area. Such a chemical signature could result from hydrothermal alteration of basic to ultrabasic rocks by a system circulating through the oceanic floor. Rocks formed in this context may show anomalous concentrations of $\mathrm{Zn}-\mathrm{Cu}$ and Au. Silva et al. (1995) also argue that contact metamorphism by the nearby Caeté granodiorite could also be responsible for the exotic mineralogy of this rock. Another unusual rock is quartz-chloritoid schist with up to $70 \%$ chloritoid. The origin of this rock is uncertain. Its close relationship with basic and ultrabasic rocks suggests that the amount of chloritoid can be a product of their hydrothermal alteration. Silva et al. (1995) suggest that chloritoid could also form in metasedimentary rocks with high $\mathrm{Al}$ content and high $\mathrm{Fe} / \mathrm{Mg}$ ratios.

Basic to ultrabasic metavolcanic rocks and BIFs are the main host rocks of the gold mineralization in this unit. Raposos, Juca Vieira and Ouro Fino are important deposits that were mined in the past (Vial 1980; Lobato et al. 2001b; Junqueira et al. 2007; Vial et al. 2007).

\subsubsection{Morro Vermelho Formation}

The Morro Vermelho Formation belongs to the basal portion of RVGB, overlying the Ouro Fino Formation. Zucchetti et al. (2000c) first described it as an informal unit. The contact between these two units is gradational, with increasing contribution of clastic metasedimentary rocks towards the Morro Vermelho Formation (Fig. 3). The spatial distribution of these two formations is similar, due to the close relationship between them. Thus, the Morro Vermelho Formation occurs mainly as continuous layers surrounding the Ouro Fino Formation, in the eastern border and the central-western sector of the NLC block, near the cities of Caeté and Nova Lima. It occurs in the Caeté, Gandarela, Gongo Soco, Serra da Piedade, Belo Horizonte, Nova Lima, Rio Acima and São Sebastião das Águas Claras quadrangles (Fig. 1C; Araújo et al. 2020a, b, c, d; Cavalcanti et al. 2020a, b, c, e). The contact with the overlying units is transitional to tectonic.

Zucchetti et al. (2000c) defined the type-section of the formation in road cuts from the village of Morro Vermelho to the Geriza and Correia farms in the Caeté quadrangle (Araújo et al. 2020a). Other representative outcrops occur in the Macacos stream (Zucchetti 1998), north of the Rio Acima quadrangle (Cavalcanti et al. 2020c).

The Morro Vermelho Formation consists of an alternating sequence of basic metavolcanic, clastic and chemical metasedimentary rocks. Acid/intermediate metavolcanic, metapyroclastic, metavolcaniclastic rocks and carbonaceous metapelites occur subordinately (Fig. 3). Zucchetti et al. (2000c) suggest that clastic and volcaniclastic metasedimentary rocks are subordinate in the Morro Vermelho Formation. However, field data from this project point to an important contribution of metasedimentary rocks in this formation. The base of this unit has a predominance of basic metavolcanic rocks, and the amount of clastic and volcaniclastic rocks increases towards the top (Fig. 3). We, therefore, propose to create the Roça Grande Member to represent the rock association in which metasedimentary rocks prevail over other lithotypes.

The least weathered basic metavolcanic rocks consist of light-green and fine-grained amphibolite and chloriteamphibole schists (Figs. 9A, 9B). The most common lithologies related to basic metavolcanic rocks are altered brown to red quartz-sericite-chlorite schist and chlorite schist. Thin quartz-rich layers are frequent and may represent metachert commonly intercalated with the basic volcanic rocks, or the result of silicification. In the last case, the quartzrich bands may be surrounded by sericitic and chloritic halos, and the rock presents a layering that can be misinterpreted as sedimentary bedding.

Metavolcanic rocks from the Lamego gold deposit, previously attributed to the Mestre Caetano unit (Costa 1994; Baltazar and Silva 1996; Baltazar et al. 2005b) are here considered part of the Morro Vermelho Formation, as indicated by the geological context and petrography (Figs. 2A, 3). Metavolcanic rocks from other gold deposits such as Cuiabá and Roça Grande were attributed to this unit by Silva (1994), Baltazar and Silva (1996), and Baltazar et al. (2005a), and remain in this position. Since the outcrops of the basic metavolcanic rocks of the Morro Vermelho Formation are usually weathered, their characterization is better achieved in exposures in these deposits. In the Cuiabá deposit, these rocks occur as two main packages separated by a mineralized BIF layer. The lower basic volcanic rocks form a thick succession of light-green, massive, fine-grained rocks with clinozoisite, plagioclase, amphibole, chlorite, and quartz. The upper basic volcanic rocks are dark olive-green, massive, and fine-grained with restricted distribution, composed of chlorite, epidote, plagioclase, and quartz (Silva 2006; RibeiroRodrigues et al. 2007). The Lamego basic metavolcanic rocks are schists composed of chlorite, plagioclase, quartz, 

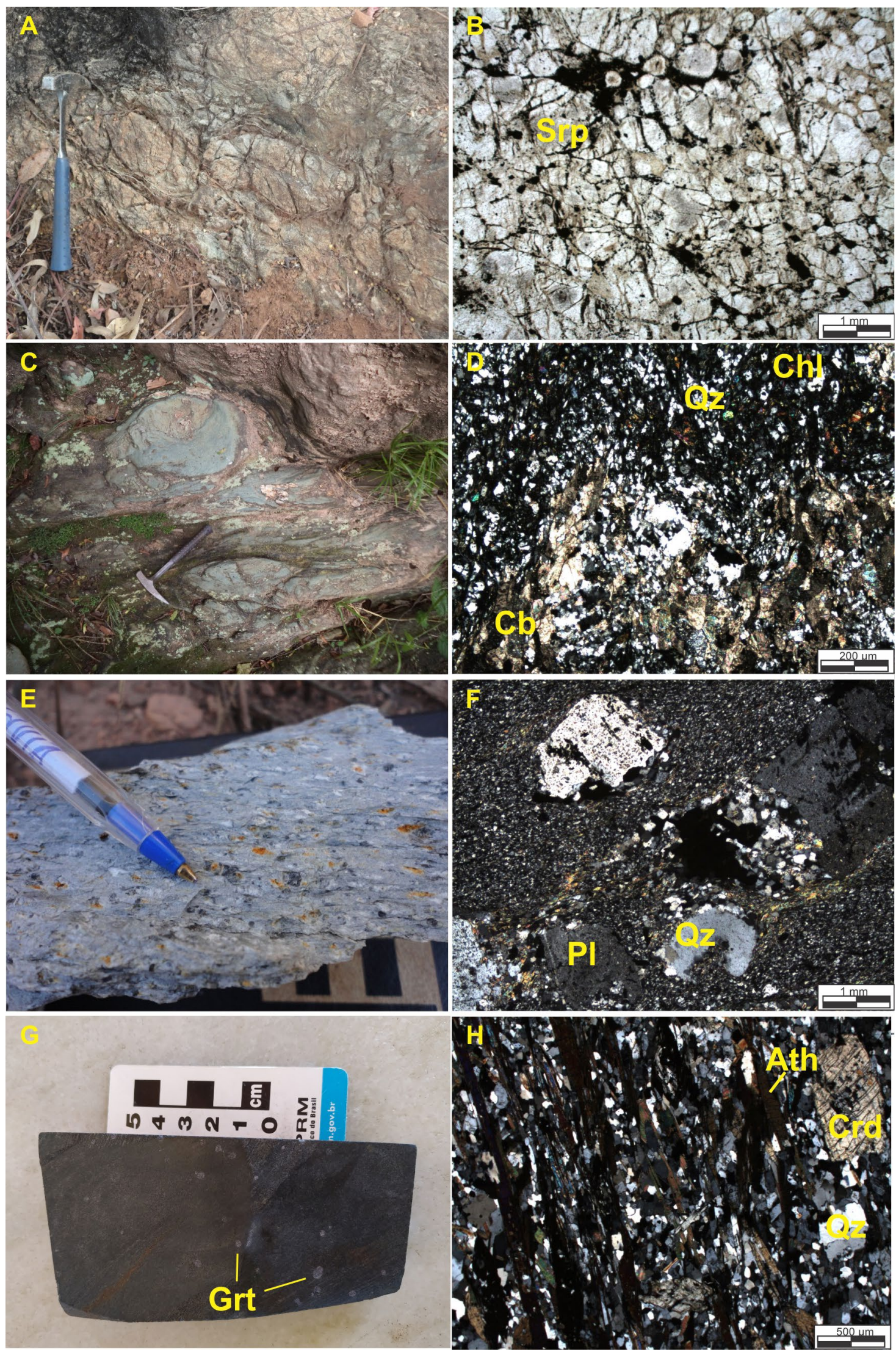

FIGURE 8. Ouro Fino Formation. (A) - Outcrop of pillowed serpentinite. (B) - Photomicrography of serpentinite with relict cumulatic texture (PPL). (C) - Outcrop of pillowed metabasalt. (D) - Photomicrography of silicified and carbonatized metabasalt (CPL). (E) - Hand specimen of metavolcaniclastic rock with porphyroclasts. (F) - Photomicrography of the metavolcaniclastic rock showing quartz with corrosion gulf, plagioclase, and empty vugs in a very fine-grained matrix. (CPL). (G) - Hand specimen of quartz-anthophyllite-cordierite schist with garnet porphyroblasts. $(\mathrm{H})$ - Correspondent photomicrography of the hand specimen $(\mathrm{CPL})$. Abbreviations: $\operatorname{Srp}=\operatorname{serpentine;} \mathrm{Qz}=\mathrm{quartz} ; \mathrm{Cb}=$ carbonate. $\mathrm{PI}=$ plagioclase; $\mathrm{Grt}=$ garnet; Ath = anthophyllite; $\mathrm{Crd}=$ cordierite. 
carbonate, and minor amphibole (Martins et al. 2016; Araújo 2018). In the Roça Grande deposit, these rocks are chloritehornblende schists with minor quartz, plagioclase, epidote, and carbonate (Araújo 2018).

BIF and metachert layers occur throughout the Morro Vermelho Formation (Zucchetti et al. 2000c), but are more concentrated in the basal section of this unit (Fig. 3). These rocks are particularly abundant in the Nova Lima and Morro Vermelho areas (Fig. 2A), where thick and continuous layers stand out in the landscape as prominent crests. Discontinuous and extremely folded BIF layers are also common. They are in contact with both metavolcanic and clastic metasedimentary rocks, and commonly, with carbonaceous phyllite layers (Fig. 9C). These BIFs have a $\mathrm{mm}$ to $\mathrm{cm}$-thick layering given by quartz-rich layers of metachert, alternating with layers with ironrich minerals (Figs. 9C, 9D). In outcrops at the land surface, the iron-rich minerals are commonly oxidized to goethite with remains of magnetite and hematite. In contrast, Araújo and Lobato (2019) report that underground BIF exposures in the gold mines (e.g., Cuiabá, Lamego, Roça Grande) consist of iron carbonates, oxides and silicates.

The most common clastic metasedimentary rocks of this unit are metapelites, feldspar-quartz metagreywackes. Quartz-chlorite schists are metapelites with an important basic contribution, whereas chlorite-sericite-quartz schists have a mixed or more acid source. These metasediments are here interpreted as volcanogenic sedimentary deposits of the McPhie et al. (1993) classification.

Acid to intermediate metavolcanic and metavolcaniclastic rocks are subordinate lithotypes of the Morro Vermelho Formation. They consist of meta-agglomerates (Fig. 9E), plagioclase-sericite-quartz schists, plagioclase-carbonatequartz-chlorite schists, and sericite-quartz schist, often myllonitized. Porphyroclasts of partially sericitized plagioclase and grayish-blue quartz with corrosion gulfs are common (Fig. $9 F)$. These rocks are more frequent in the Nova Lima region, the western part of the block (Fig. 2A), than in its eastern sector (Caeté area).

\subsection{Roça Grande Member}

Clastic and volcaniclastic metasedimentary rocks are frequent in the Morro Vermelho Formation, and they prevail in the upper section of this unit, named Roça Grande Member (Table 1; Figs. 2A, 3). The Roça Grande Member includes metapelites, chlorite-rich metapelite, lithic, feldspathic, and quartz metagreywackes (Figs. 9G, 9H) interbedded with metavolcaniclastic rocks, subordinate BIF, metachert, carbonaceous phyllite, and basic metavolcanic rocks.

The representative outcrops of this new unit occur near the Roça Grande gold deposit, in the Caeté and Gongo Soco quadrangle (Araújo et al. 2020a, d). Good outcrops also occur to the south of the Morro Vermelho village and near the Apolo Project (Vale S.A.), to the northwest of the Gandarela Syncline, in the Gandarela quadrangle (Araújo et al. 2020c), especially in the Maquiné waterfall. The type section occurs northeast of this waterfall, where BIF, metagreywackes, and metapelites are interbedded. The Roça Grande member is in transitional contact with the undivided Morro Vermelho Formation and tectonic contact with the Minas Supergroup.

4.2.2.3. Mestre Caetano Formation
Zucchetti et al. (2000c) first described the Mestre Caetano Formation as an informal unit. Its stratigraphic position corresponds to the intermediate portion of the RVGB, overlying the Morro Vermelho Formation and underlying the Ribeirão do Brumado Formation (Table 1; Figs. 2A, 3). A thrust fault obliterates the original contact between these units. It crops out as continuous layers of the NLC block central and western portions, which corresponds to the Belo Horizonte, Nova Lima, Rio Acima, Santa Luzia and São Sebastião das Águas Claras quadrangles (Fig 1C; Cavalcanti et al. 2020a, b, $\mathrm{c}, \mathrm{d}, \mathrm{e})$. The formation becomes less exposed to the east, in the Caeté and Serra da Piedade quadrangles (Fig. 2A; Araújo et al. 2020a, d).

The Mestre Caetano Formation consists mainly of metavolcaniclastic rocks. This formation includes the Ribeirão Vermelho and Mestre Caetano informal units defined by Zucchetti et al. (2000c), as part of what the authors called Volcaniclastic lithofacies. We here propose to formalize the Mestre Caetano Formation to represent these metavolcaniclastic rocks. We propose to subdivide it into two members (Table 1; Figs. 2A, 3). One, the Ribeirão Vermelho Member with prevailing metapyroclastic rocks, which partially corresponds to the Ribeirão Vermelho unit of Zucchetti et al. (2000c), and another, the Macacos Member (Cavalcanti et al. 2020e), made up of chlorite-rich metapelites interbedded with metavolcaniclastic rocks.

The type-section of this formation outcrops to the northeast of the block, along the Central do Brasil inactive railroad, between the city of Caeté and the village of Pompéu. There, volcanic meta-agglomerates and metatuffs transition to volcaniclastic and volcanogenic metagreywackes. Typical outcrops also occur in the central portion of the block, near Rio Acima city, in Viana and Cortesia streams (Zucchetti et al. 2000c; Baltazar and Pedreira 2000).

The undivided Mestre Caetano Formation has a broad distribution in the Nova Lima-Caeté block, particularly in its central and western parts. It occurs as NE-SW to NNE-SSWtrending continuous layers (Fig. 2A). The unit consists of feldspathic and quartz-rich metagreywackes (Figs. 10C, 10D, 10E, 10F), and metapelites (Fig. 3), frequently interbedded as metarhythmites (Fig. 10C). Metapyroclastic rocks comprise a variety of protoliths such as ash, lapilli tuff, agglomerate, and bomb layer. Subordinate rocks comprise carbonaceous phyllite, acid to intermediate metavolcanic rocks, and BIF (Zucchetti et al. 2000c). Volcanogenic metagreywackes (Figs. 10C, 10D) are the most representative lithotypes of the formation and frequently have an intermediate composition (Zucchetti et al. 2000a; Noce et al. 2005; Baltazar and Zucchetti 2007). They comprise schists with a matrix containing variable proportions of quartz, plagioclase, sericite, and carbonate. Common porphyroclasts are of quartz with corrosion gulfs, and/or plagioclase with primary zoning growth. The grains of both minerals are often rounded to sub-rounded due to reworking. The porphyroclasts/ matrix ratio in these rocks is extremely variable. Sedimentary bedding is evident by fining-up cycles. Each cycle consists of basal quartzite or metagreywackes that grade upwards into metapelite layers. Small-scale trough and planar crossbedding may occur (Baltazar and Zucchetti 2007). These rocks represent reworked and resedimented volcaniclastic rocks. Metapelites comprise fine-grained schists with sericite, 

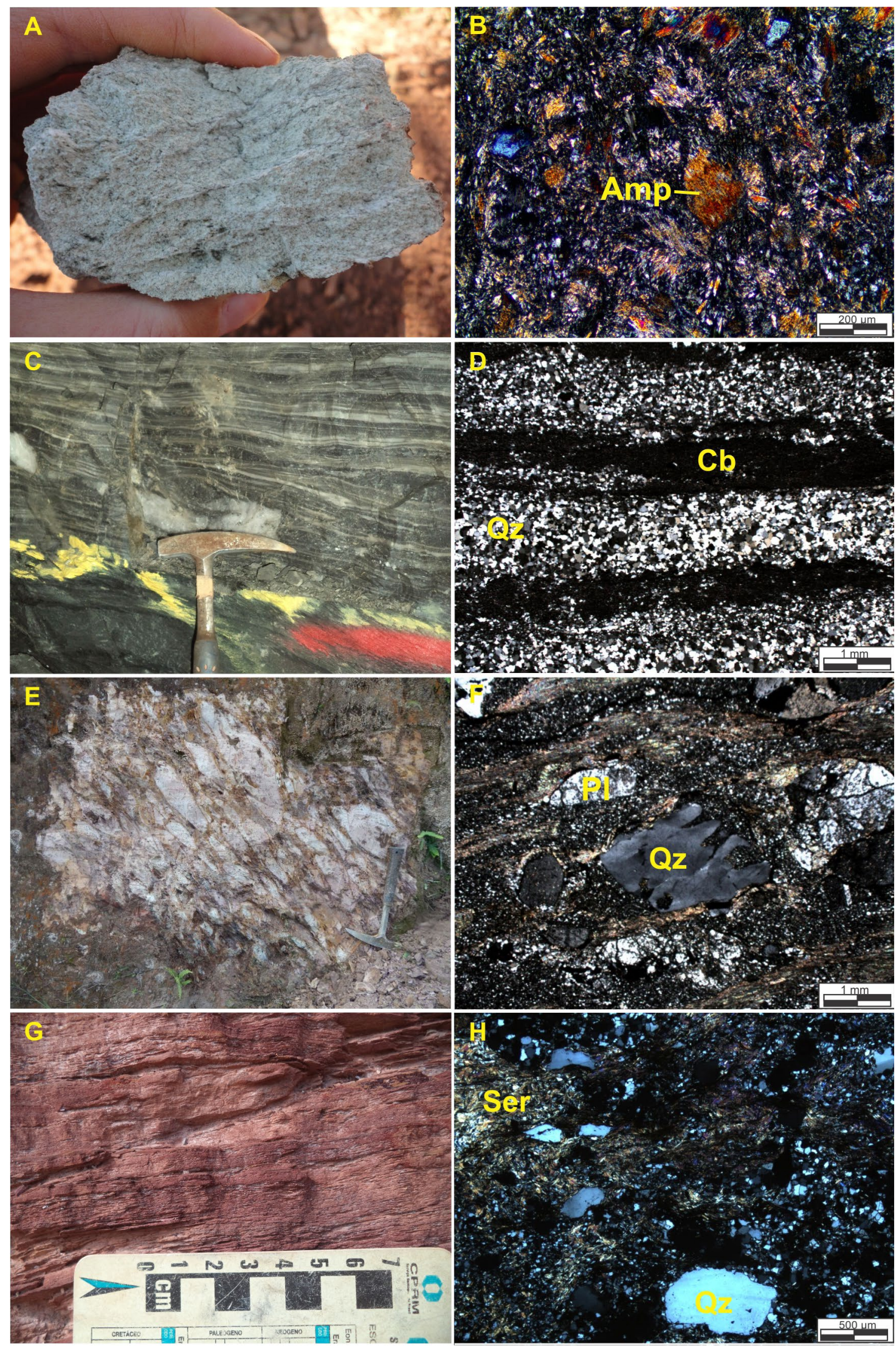

FIGURE 9. Morro Vermelho Formation and Roça Grande Member. (A) - Hand specimen and (B) photomicrography of chlorite-amphibole schist (basic metavolcanic rock) (CPL). (C) - Underground exposure of the contact between carbonate-rich BIF (top) and carbonaceous phyllite (base). Roça Grande mine. (D) - Photomicrography of BIF, with quartz-rich layers interbedded with carbonate-rich layers (PPL). (E) - Outcrop of metaagglomerate. (F) - Metavolcaniclastic rock (feldspathic metagreywacke) with porphyroclasts of plagioclase and gulf-corroded quartz (CPL); (G) Outcrop and $(\mathrm{H})$ photomicrography (CPL) of a quartz metagreywacke (sericite-quartz schist), more common in the Roça Grande Member. Abbreviations: $\mathrm{Amp}=$ amphibole; $\mathrm{Qz}=$ quartz; $\mathrm{Cb}=$ carbonate; $\mathrm{PI}=$ plagioclase Ser = sericite. 

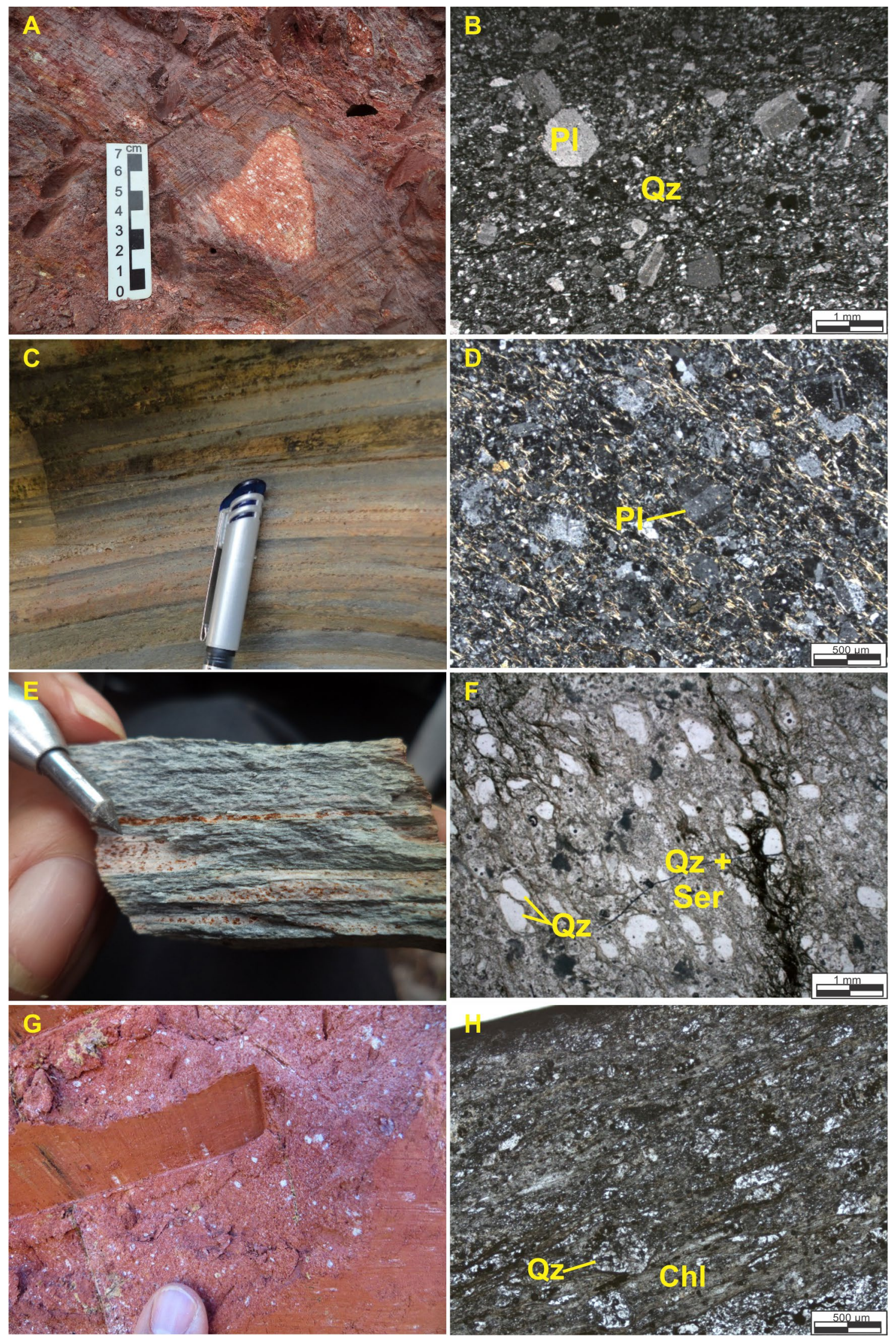

FIGURE 10. Mestre Caetano Formation. (A) - Outcrop of meta-agglomerate showing felsic bombs. (B) - Photomicrography of a quartzfeldspathic meta-agglomerate matrix (CPL), both of the Ribeirão Vermelho Member. (C) - Outcrop of a volcaniclastic metarhythmite (feldspathic metagreywacke) with preserved original bedding. (D) - Photomicrography of a metagreywacke with preserved well-formed plagioclase crystals (CPL). (E) - Hand sample of a quartz-rich metagreywacke containing quartz veins with boxworks filled with oxidized minerals. (F) - Photomicrography of the hand sample that shows irregular quartz porphyroclasts in a very fine-grained quartz-sericite matrix (PPL). (G) - Outcrop of a quartz metagreywacke of the Macacos Member, with a red and ferruginous matrix. $(\mathrm{H})$ - Photomicrography of the hand sample showing quartz porphyroclasts in a chlorite-rich matrix (PPL). Abbreviations: $\mathrm{Qz}=$ quartz; $\mathrm{PI}=$ plagioclase; Ser = sericite; $\mathrm{Chl}=$ chlorite. 
chlorite, quartz, and carbonate. Meta-agglomerates, bombs, and tuffs occur subordinately in the undivided Mestre Caetano Formation, mainly in the Nova Lima region.

A peculiar rock locally known as Lapa Seca belongs to the Mestre Caetano Formation (Fig. 3). It is an important hostrock for the orogenic gold deposits of the RVGB, such as the giant Morro Velho inactive mine (> $450 \mathrm{t} \mathrm{Au}$ ), and the Bicalho and Bela Fama deposits (Lobato et al. 2001b). It consists of a foliated, homogeneous to thin-banded, gray to whitish-gray rock composed of ferroan dolomite, ankerite, and siderite. Quartz, calcite, sericite, fuchsite, chlorite, and albite are varietal minerals (Ladeira 1980; Ladeira 1985). The genesis of the Lapa Seca rocks has been intensely debated. Ladeira (1980) and Vial (1980) interpret these rocks as a product of chemical sedimentation, whereas Vial et al. (1987), Vieira (1991), and Lobato et al. (2001b) suggest a hydrothermal origin for this particular rock.

\subsection{Ribeirão Vermelho Member}

Zucchetti et al. (2000c) first defined the Ribeirão Vermelho unit as an informal unit containing predominantly metapyroclastic rocks and named it after the homonymous river with representative outcrops. Good exposures also occur along the Caeté River, and the Central do Brasil inactive railroad, to the west of the city of Caeté, in the Serra da Piedade quadrangle (Araújo et al. 2020b). The contact with the Morro Vermelho, Ribeirão do Brumado, and the undivided Mestre Caetano formations is tectonic. Thin and discontinuous pyroclastic layers also occur in the Nova Lima region. However, the Ribeirão Vermelho Member is only mappable in the Caeté area at the 1:25,000 scale (Fig. 2A).

The metapyroclastic deposits of this member comprise agglomerates, bomb layers, lapilli tuffs, and ash tuffs, and subordinate carbonaceous phyllite, and rare acid/ intermediate metavolcanic rocks. These rocks are, in general, deeply weathered (Fig. 3). Meta-agglomerates (Fig. $10 \mathrm{~A}$ ) have an intermediate to basic tuffaceous matrix with variable proportions of quartz, feldspar, chlorite, sericite (Fig. 10B), and occasionally also carbonaceous matter. The fragments show a considerable size range and can reach up to $40 \mathrm{~cm}$. They are either feldspar and quartz crystals or lithic fragments of variable forms (angular to rounded) and compositions (mainly dacitic and andesitic). The lapilli metatuffs are beige to red schists with fine-grained quartz, feldspar, sericite, chlorite, and coarse grains of prismatic plagioclase, lithic fragments and grayish-blue quartz with corrosion gulfs under the microscope. The most weathered outcrops present plentiful and millimetric white spots resulting from the transformation of feldspar into kaolin. The cineritic metatuffs are argillaceous and altered rocks mainly composed of white clay and very fine-grained quartz. The subordinated volcaniclastic and volcanogenic metasedimentary rocks are metagreywackes and metapelites. The rare exposures of felsic metavolcanic rocks have a dacitic composition and preserve the original porphyritic texture, with a quartzfeldspathic matrix with plagioclase, subordinate hornblende phenocrysts (Zucchetti et al. 2000b). The coarse and poorly sorted conglomerates and breccias were interpreted as alluvial-fans formed near an island arc explosive volcanic center (Zucchetti et al. 2000a; Noce et al. 2005; Baltazar and Zucchetti 2007).

\subsection{Macacos Member}

Cavalcanti (2018) first defined the Macacos Member as an informal unit. It is restricted to the western part of the NLC block, in the São Sebastião das Águas Claras quadrangle (Cavalcanti et al. 2020e), cropping out around the homonymous village, also known as Macacos. It is in tectonic contact with the Ouro Fino, Morro Vermelho, and the undivided Mestre Caetano formations and with the Minas Supergroup. Representative outcrops are located on the road that leads to the Passagarda condominium, near the Macacos village. Due to the lithologic and depositional environment similarities with the Mestre Caetano Formation, we propose to consider this unit as part of this formation in the rank of a formal member.

It differs from the undivided Mestre Caetano Formation by the abundant chloritic metapelites and metagreywackes (Figs. 10G, 10H), which were interpreted by Cavalcanti (2018) as volcaniclastic and volcanogenic metasedimentary rocks derived from basic to intermediate sources. Metapelites and metagreywackes derived from felsic sources also occur interbedded in the package. Carbonaceous and noncarbonaceous phyllites, BIFs, basic and ultrabasic intrusions are subordinate (Cavalcanti et al. 2020e). Chlorite-rich rocks are red when weathered and interbedded with schists containing variable proportions of sericite, quartz, and plagioclase. The metagreywackes consist of quartz, plagioclase, and fragments of volcanic rocks. Plagioclase crystals sometimes preserve their prismatic habit, and quartz grains may have corrosion gulfs, though angular or sub-rounded grains that suggest reworking, are also common.

\subsubsection{Ribeirão do Brumado Formation}

We here formally propose the Ribeirão do Brumado Formation to enclose the rocks of the informal units named Córrego do Sítio and Mindá of the Nova Lima-Caeté block, defined in the SB block by Zucchetti et al. (2000c). Rocks of these units consist of rhythmic depositional cycles of greywacke-argillite that were interpreted as turbidites of the resedimented volcaniclastic lithofacies. However, once they crop out in two distinct tectonic blocks and, therefore, may probably represent different source-area, sedimentary processes, and environment, we prefer to consider them as separate units. For example, the geochemical data obtained by Baltazar and Zucchetti (2007) suggest that the original sediments of the northern sector (NLC block) derived from a felsic source-area. In contrast, those of the eastern sector (SB block) derived either from a mixed or felsic source-area.

The Ribeirão do Brumado Formation crops out as continuous layers widely distributed in the NLC block (Fig. 2A), being present in the Caeté, Gandarela, Serra da Piedade, Belo Horizonte, Nova Lima, Rio Acima, Santa Luzia, São Sebastião das Águas Claras, Capanema, Itabirito and Rio de Pedras quadrangles (Fig. 1C; Araújo et al. 2020a, b, d; Cavalcanti et al. 2020a, b, c, d, e; Freitas et al. 2020a, b, c).

The formation comprises metasedimentary rocks (Fig. 3), which we formally propose to assemble into the psammitic Ribeirão Comprido and the pelitic Ribeirão do Gaia members. They are genetically correlated, and represent the proximal and distal facies of turbidites derived from the 
underlying greenstone belt sequence. The contact between both members is transitional and, with other stratigraphic units of the Rio das Velhas Supergroup and with the Minas Supergroup, the contact is tectonic.

\subsection{Ribeirão Comprido Member}

The Ribeirão Comprido Member is restricted to the NLC block and corresponds to the Mindá unit defined in the SB block by Zucchetti et al. (2000c). The type-section occurs along a dirt road inside the Bom Sucesso farm, north of the Morro Vermelho village. Representative outcrops also occur along the dirt road from the city of Sabará to the village of Morro Vermelho. In the type-section, psammitic layers prevail over pelitic ones. The metarhythmites (Figs. 11A, 11B) exhibit thick metagreywacke/quartzite layers grading into metasiltstones (sericite-quartz schist) and metapelites (quartz-chlorite-sericite phyllite).

Quartz metagreywackes (sericite-quartz schist and quartz-chlorite-sericite schist) are the most common rocks of the Ribeirão Comprido Member (Figs. 11B, 11C, 11D). They are rocks rich in sand-sized quartz with different proportions of a fine-grained matrix. Magnetite crystals up to $1 \mathrm{~cm}$ are frequent, as well as square-shaped boxworks, empty or filled with ocher to red secondary minerals (Fig. 11C). The metarhythmites show fining-upward cycles with sand layers at the base and mud layers at the top. The sand layers are thicker and may contain small-scale, low-angle (up to $20^{\circ}$ ) tabular cross-bedding and symmetrical to asymmetrical ripple-marks. The pelitic layers of the top have planar stratification. Layers of mylonitic sericite-quartz schist are common and stand out in the landscape as small crests, a typical geomorphological feature of this member. Feldspathic metagreywackes, colorful phyllites, and carbonaceous phyllite occur subordinately.

\subsection{Ribeirão do Gaia Member}

This member corresponds to the Córrego do Sítio unit defined by Zucchetti et al. (2000c) in the SB block and consists of fine-grained metasedimentary rocks composed of silt and clay-sized particles with subordinate sandy layers. Representative outcrops are found in the Gaia stream and in the dirt road from the city of Sabará to the Morro Vermelho village, where greywacke-argillite metarhythmites are preserved. These metarhythmites are characterized by decimetric finingupward cycles with thin layers of metagreywackes or fine quartzites at the base grading into thicker metapelite layers at the top, interpreted as a turbidite sequence.

Metapelites of variable colors (gray, red, ocher, lilac) are the most common rocks of this member (Fig. 11E). They are composed of variable proportions of quartz, sericite, and chlorite (Fig. 11F). Magnetite, plagioclase, and carbonate are subordinate. Layers of carbonaceous phyllite are common. Quartz and feldspathic metagreywacke (sericite-quartz schist and sericite-plagioclase-quartz schist) are subordinate. White to beige potassium-rich weathered rocks are commonly interbedded in this package as centimetric to metric layers with white clay, sericite, and very fine-grained quartz. Their deep alteration hinders the recognition of the protolith but, considering the geological context, they probably are tuffaceous rocks.

\subsubsection{Nova Lima Group in the SBT block}

The Nova Lima Group in the São Bartolomeu block is here divided into three formations named, from base to top, as Fazenda Velha, Córrego da Paina and Pau D'Óleo. Ribeiro and Tuller (1996), Féboli and Signorelli (1996), and Signorelli et al. (1996) report that in the SBT block, outside the area covered in this paper, the Nova Lima Group contains a unit called Catarina Mendes. However, detrital zircon U-Pb isotopic data obtained by Freitas et al. (2019) yielded a Rhyacian maximum depositional age and correlated it with the Sabará Group.

\subsubsection{Fazenda Velha Formation}

The Fazenda Velha Formation (Féboli and Signorelli 1996) was first described as an informal unit of metasedimentary rocks restricted to a E-W-trending layer parallel to the Andaimes and Pau D'Óleo formations at the southwest of the Rio Acima city (Fig. 2A). It outcrops along the northern side of the Andaimes range, in the Itabirito quadrangle (Freitas et al. 2020b), where it is limited to the north by the Ribeirão do Brumado Formation through the Bem-te-Vi fault, the northern border of São Bartolomeu block. To the south, it is in tectonic contact with the Pau D'Óleo Formation and, to the east, in transitional contact with the Córrego da Paina Formation. To the west, the Fazenda Velha Formation is thrusted on the younger sequences of the Minas Supergroup.

The type-area of the Fazenda Velha Formation is located next to the homonymous farm, along the Ferrovia do Aço ("Iron Railroad"). Good exposures also occur along the MG030 road. Another area with outcrops that correlate with the Fazenda Velha Formation is located to the west of the São Bartolomeu District. It is a N-S layer parallel to the Bação Complex east border, but it occurs outside the area covered in this phase of the project.

The main lithotypes of Fazenda Velha Formation are gray, green, white, or yellow plagioclase-chlorite-quartz schists, sericite-plagioclase-biotite-chlorite-quartz schists, carbonatebiotite-plagioclase-quartz-sericite schists, and carbonaceous phyllite (Figs. 3, 12A). Under the microscope, they show a compositional banding given by $\mathrm{mm}$ - to $\mathrm{cm}$-thick layers rich in chlorite, biotite, white mica, and carbonate, alternating with layers of quartz and feldspar.

The protolith was interpreted as being a greywacke (Fig. $12 \mathrm{C}$ ), arranged in $\mathrm{cm}$ - to m-thick fining-upward cycles with thin layers of carbonatic meta-argillite and dark-grey carbonaceous meta-argillites (Fig. 12B) at the top of cycles, which defines metarhythmites with sharp basal contact (Fig. 12D). Primary preserved structures in these rocks include graded bedding and small to medium-scale tabular and trough cross-bedding. The presence of quartz grains with corrosion and bipyramidal features (Fig. 12F) suggests a volcanogenic provenance for the sedimentary protolith.

\subsubsection{Córrego da Paina Formation}

The Córrego da Paina Formation was first described by Féboli and Signorelli (1996) as an informal unit. It occurs in tectonic contact, locally metamorphic, around the basement rocks of the Bação Complex (Fig. 2A). The contacts are transitional with the Pau D'Óleo and Fazenda Velha formations. Thrust and transverse fault contacts occur with 
the Minas Supergroup at the west (Fig. 13A), and with the Ribeirão do Brumado Formation at the east.

This formation occurs in the Capanema, Itabirito and Rio de Pedras quadrangles (Freitas et al. 2020a, b, c). Its type-section crops out near the Paina stream and excellent exposures occur along the BR-356 road and the EFMV railroad. The Córrego da Paina Formation consists of gray to dark green, occasionally reddish, siliciclastic rocks arranged in alternating rhythmic cycles. Each cycle comprises a graded and foliated sequence made up of fine-grained meta-arenite, metagreywacke (Fig. 13B), metasiltite, and meta-argillite. The basal layer is in sharp contact with the underlying one, and grading upwards into carbonaceous phyllite crosscut by white quartz veinlets and two foliations (Fig. 13C). The lower layer is plane-parallel and smallscale cross-stratified, and consists of fine-grained quartz, plagioclase, and phyllosilicate, with rare dispersed granules. The phyllosilicates of all layers occur in variable proportions of sericite, biotite, and chlorite. Local thin layers of carbonaceous phyllite are interbedded with stratiform tourmalinites (Fig. 13D) and carbonatic and weakly magnetic BIF lenses, with concentrations of opaque minerals.

The Córrego da Paina Formation hosts few gold occurrences, particularly in its western portion, along the E-W trending sinistral Cata Branca fault (Fig. 13A), which is the contact with the Minas Supergroup.

\subsubsection{Pau D’Óleo Formation}

The Pau D'Óleo Formation was first proposed by Féboli and Signorelli (1996) as an informal unit. It occurs in the
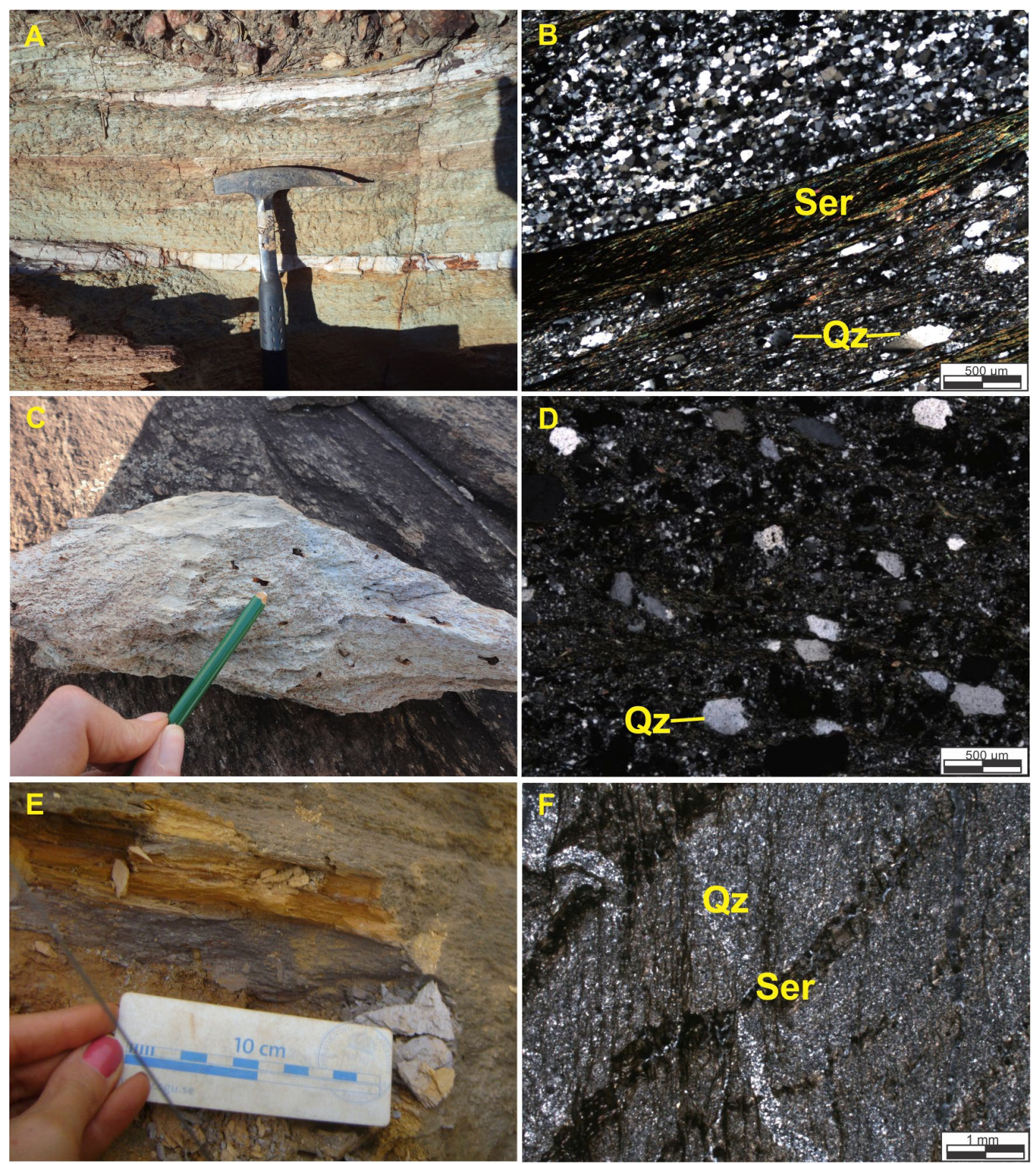

FIGURE 11. Ribeirão Comprido Member of the Ribeirão do Brumado Formation. (A) - Outcrop of coarse-grained metarhythmite. (B) - Photomicrography of a thin sericite layer interbedded with quartz-rich layers of the metarhythmite (CPL). (C) - Hand sample of metagreywacke with boxworks of oxidized magnetite porphyroblasts. (D) - Photomicrography of hand sample showing quartz porphyroclast in a quartz-sericitic matrix (CPL). Ribeirão do Gaia Member: (E) - Outcrop of fine-grained quartz-sericite phyllite. $(F)$ - Photomicrography of a very fine-grained sericite-quartz metapelite (CPL). Abbreviations: $\mathrm{Qz}=$ quartz; Ser = sericite. 

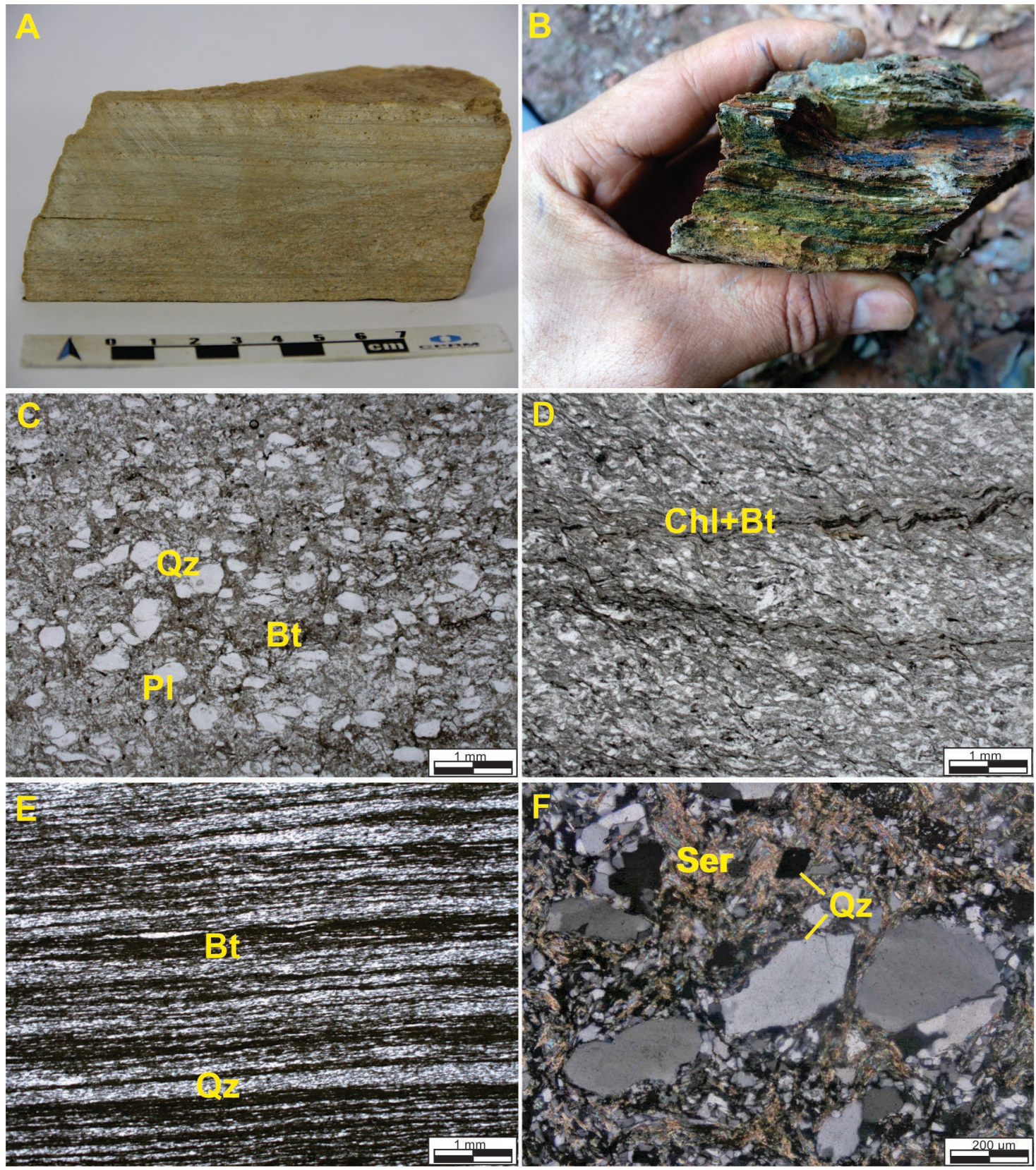

FIGURE 12. Fazenda Velha Formation. (A) - Hand-sample of rhythmic layered metagreywacke. (B) - Hand-sample of a carbonaceous meta-argillite. (C) - Photomicrography of metagreywacke with angular quartz and plagioclase fragments in a biotite matrix (PPL), (D) - Photomicrography of metargillite crosscut by a spaced crenulation cleavage (PPL). (E) - Photomicrography of metargillite with rhythmic lamination (PPL). (F) Photomicrography of metagreywacke with quartz porphyroclasts showing corrosion and bipyramidal features immersed in a phyllosilicate matrix $(\mathrm{CPL})$. Abbreviations: $\mathrm{Qz}=$ quartz; $\mathrm{Bt}=$ biotite; $\mathrm{PI}=$ plagioclase; $\mathrm{Chl}=$ chlorite; Ser = sericite.

northern portion of the São Bartolomeu block (Fig. 2A) as an E-NE elongate rock body in tectonic contact surrounding the Andaimes Formation in the north of the city of Itabirito. Its southern contact is transitional with the Córrego da Paina Formation, by thrust-fault with the Fazenda Velha Formation at the north, and the Minas Supergroup at the west. The typearea occurs in the Pau D'Óleo ridge to the south of the Bem$\mathrm{Te}-\mathrm{Vi}$ fault, in the Itabirito quadrangle (Freitas et al. 2020b). Good outcrops also occur alongside the Steel railroad and the Luzia dos Santos and Campestre streams.

The formation consists of white-gray to yellow, tabular to trough cross-bedded, fine- to medium-grained metagreywacke (Fig. 14A, 14B) meta-arenites, and meta-argilites. These rocks are plagioclase-carbonate-chlorite-quartz-mica schist with folded compositional banding and transposed schistosity. Compositional banding is given by thicker bands with sericite and chlorite alternating with thinner ones of quartz, feldspar, and carbonate, representing rhythmic greywackeargillite cycles. Their grain-size may be very fine due to low recrystallization (Fig. 14C) or fully recrystallized in greenschist facies with well developed granoblastic and lepidoblastic textures (Fig. 14D).

\subsection{Maquiné Group}

The Maquiné Group comprises three main formations: Palmital, Andaimes, and Casa Forte. The Palmital and Casa Forte formations occur in the Nova Lima and Santa 
Bárbara blocks, while the Andaimes Formation outcrops only in the São Bartolomeu block. The group consists mainly of quartzites and metaconglomerates that are more resistant to erosion than the underlying Nova Lima Group and stand out in the landscape as scarps and steep slopes (Dorr II 1969).

\subsubsection{Palmital Formation}

The Palmital Formation (O'Rourke 1957) comprises the clastic metasedimentary sequences of the Rio das Velhas Supergroup upper portion (Dorr II 1969). The type-section is in the Rio de Pedras and Buraco regions (Gair 1962) of the NLC block, present in the Caeté, Gandarela, Nova Lima, Rio Acima and Rio de Pedras quadrangles (Fig. 1C; Araújo et al. 2020a, b; Cavalcanti et al. 2020b, c; Freitas et al. 2020c). In the SB block, the most representative exposures of this formation occur in the Capanema (Freitas et al. 2020a), and Conceição do Rio Acima quadrangles (Ferreira et al. 2020b). Thrust-faults are the contacts between this formation and the other units of the Nova Lima and Maquiné groups.

The rocks of this formation comprise metagreywacke, quartzites, and metapelites. Preserved primary structures occur locally, such as tabular and trough cross-bedding (Figs. $15 \mathrm{~A}, 15 \mathrm{~B})$. The metagreywackes/quartzites are micaceous quartzites, chloritoid quartzites, quartz-mica schists, and (chloritoid)-chlorite-muscovite/sericite-quartz schists. Their mineral associations comprise rounded to angular, mediumgrained sand-sized to silt quartz grains in a micaceous matrix (Fig. 15C, 15D). Oriented chlorite and sericite may form thin anastomosed laminae bordering stretched quartz grains (Fig. 15E). Minor mineral phases comprise chloritoid, kyanite, and variable amounts of magnetite, zircon, rutile, and albite. Chloritoid crystals have hourglass texture and may form radial aggregates (Fig. 15F), whereas kyanite is common near the tectonic contacts with other units, or associated with quartz veins. Magnetite is also common, as well as square-shaped boxworks, and a ferruginous crust often covers these rocks. Metapelites and carbonaceous phyllites are subordinate and correspond to fine-grained quartz-chlorite-sericite schists.

\subsubsection{Andaimes Formation}

Several authors considered the Andaimes Formation a member of the Palmital Formation (Baltazar and Silva 1996; Féboli and Signorelli 1996; Zucchetti and Baltazar 2000). Other authors considered it as a top unit of the Nova Lima Group (Belo de Oliveira 1986; Hartmann et al. 2006). However, Freitas et al. (2020b) and Silva et al. (2020) consider these rocks as a separate formation of the Maquiné Group.

In the northern portion of the São Bartolomeu block, the quartz-rich rocks of this formation sustain an east-westtrending ridge that controls the channel of the Andaimes stream. The structural features of the Andaimes ridge led Baltazar and Zucchetti (2007) to interpret it as the core of an overturned syncline, marked by bedding folds with an axial
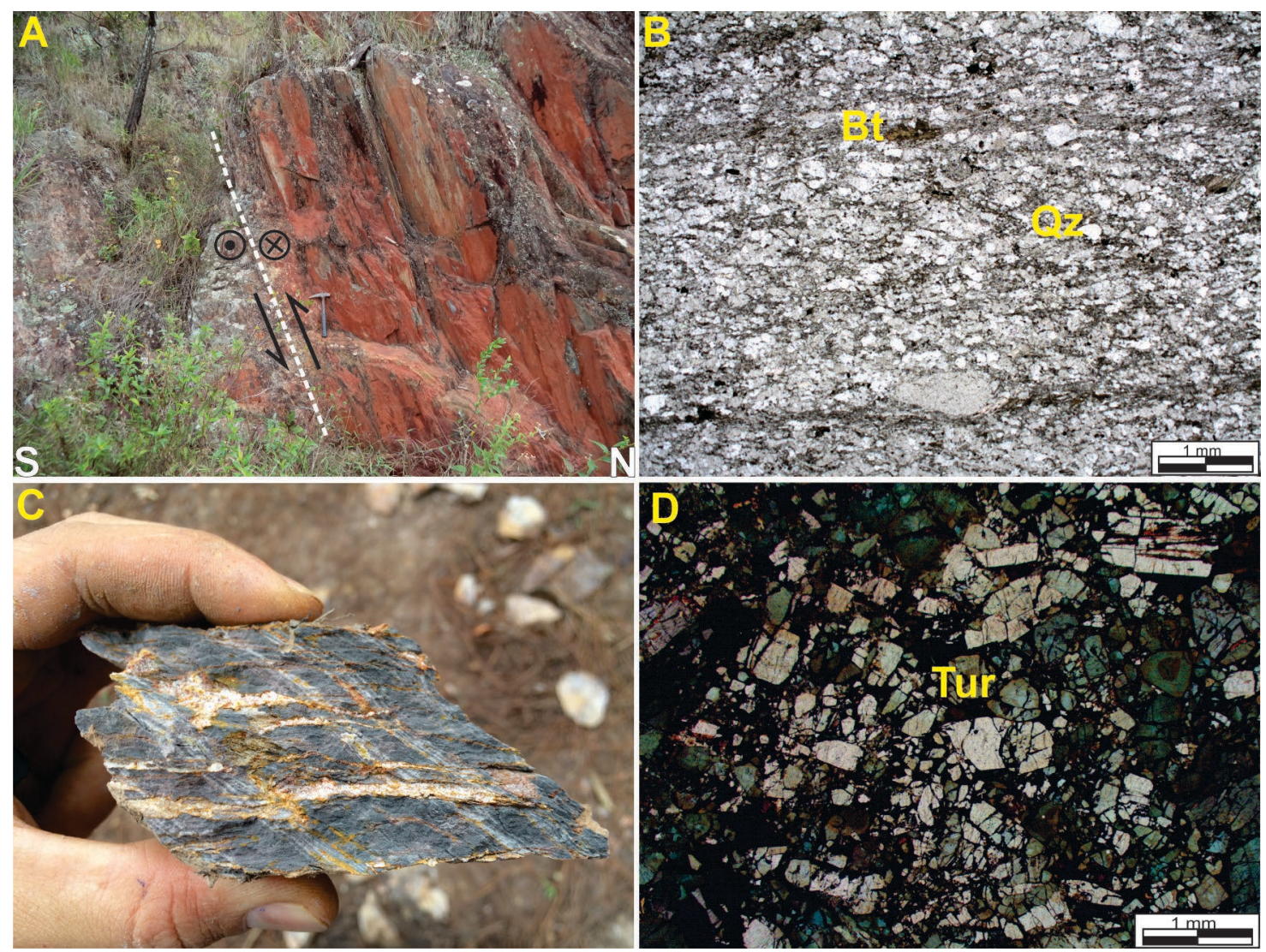

FIGURE 13. Córrego da Paina Formation. (A) - Outcrop of the Cata Branca fault, the contact between the Córrego da Paina Formation and the Minas Supergroup (block to the right). (B) photomicrography of a metagreywacke showing rhythmic alternation with phyllosilicates levels (PPL). (C) - Hand-sample of carbonaceous phyllite with white quartz veinlets and two foliations, (D) - Photomicrography of tourmalinite. (PPL). Abbreviations: $\mathrm{Qz}=$ quartz; $\mathrm{Bt}=$ biotite; Tur = tourmaline. 

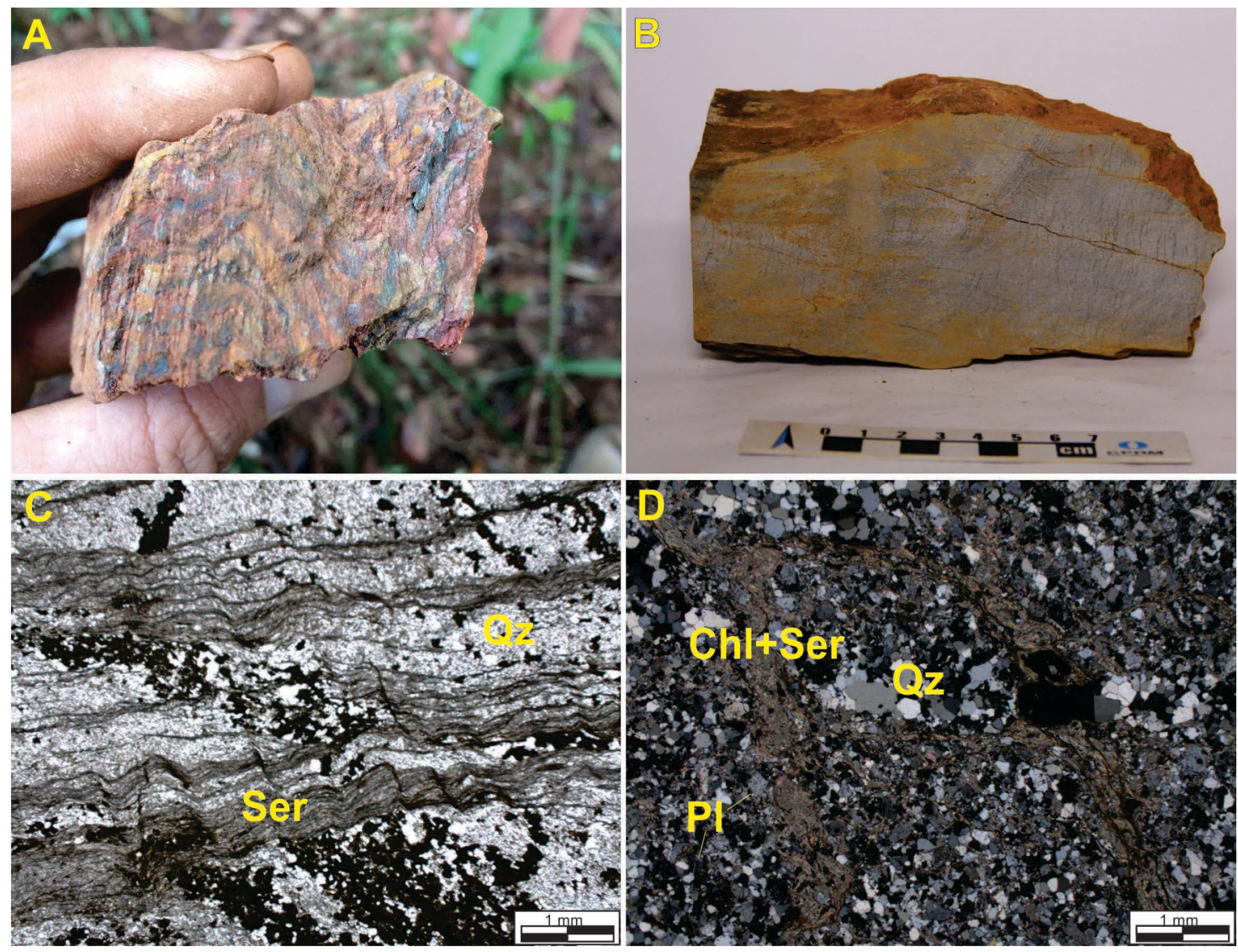

FIGURE 14. Pau D'Óleo Formation. (A) - Hand sample of metagreywacke showing a folded compositional banding with an axial-plane schistosity. (B)- Hand sample of a massive metagreywacke. (C) - Photomicrography of a rhythmic meta-argillite/meta-arenites showing a lamination given by sericite and quartz layers and a crenulation cleavage (PPL); (D) - Photomicrography of a metagreywacke with lepidoblastic and subordinate granoblastic textures (CPL). Abbreviations: $\mathrm{Qz}=$ quartz; $\mathrm{Ser}=$ sericite; $\mathrm{PI}=$ plagioclase. $\mathrm{Chl}=$ chlorite .

foliation. The Pau D'Óleo Formation surrounds the formation in tectonic contact. A thrust-fault marks its edge with the Minas Supergroup to the west (Fig. 2A).

Good outcrops of this formation occur along an old track in the Andaimes ridge that leads to the railway terminal, in the Itabirite quadrangle (Freitas et al. 2020b). In the NLC block, it crops out as metasandstone klippen overriding metabasalts of the Ouro Fino Formation, turbidites of the Ribeirão do Brumado Formation, and along the Bem-Te-Vi fault, which is the contact between both blocks.

Rocks of Andaimes Formation are medium- to finegrained, white micaceous metasandstones, and yellow when altered. Well-preserved primary sedimentary structures are small asymmetric ripple-marks (Fig. 16A), and herringbone cross-stratification (Fig. 16B). Subordinate rock-types are $\mathrm{cm}$ - to m-thick layers and lenses of microconglomerates (Fig. 16C) and mica-quartz schists (metasiltstone). The microconglomerates are polymictic, matrix-supported, and the clasts are metachert, quartz-vein, quartzite, and schist. Some quartz grains have bipyramidal shape and embayments (Fig. 16D), suggesting volcanic provenance. The matrix consists of sericite and fine-grained quartz.

The metasandstones of the Andaimes Formation correspond to the coastal lithofacies association of Baltazar and Zucchetti (2007). The authors describe that the metasandstones occur as four different facies: (i) with medium- to large-scale cross-bedding; (ii) with small ripple marks; (iii) with herringbone cross-bedding, and (iv) associated with metasiltstone. The planar and crossbeddings in metasandstones of the first facies correspond to Allen's (1963) Xi type, with cuneiform terminations. Pedreira and Silva (1996) interpreted this facies as former barchan type dunes. The same authors suggest that the deposition of these facies occurred in an eolian environment characterized by bimodal grain size, lack of internal cross-lamination, small amplitude and large wavelength ripple-mark index (wavelength/amplitude) greater than 10 (Tucker 1996). Metasandstones of the second facies have asymmetric straight-crested ripple-marks (Allen 1968), with a ripple index around 5 , suggesting deposition in shallow water (Baltazar and Zucchetti 2007). Metasandstones of the herringbone cross-bedding facies indicate bidirectional cycles of tidal flow (Pedreira and Silva 1996; Baltazar and Pedreira 2000). Locally, metasandstones of this facies display tidal bundles. The sandstone-siltstone fourth facies has planar and trough cross-bedding suggesting deposition under shallow marine conditions, such as a tidal plain (Féboli and Signorelli 1996).

\subsubsection{Casa Forte Formation}

The Casa Forte Formation overlies the Palmital Formation and corresponds to the non-marine lithofacies association of Baltazar and Zucchetti (2007). Dorr II (1969) suggested a gradational contact between the Palmital and the Casa Forte formations. However, recent studies indicate that the contact is an angular unconformity, and a thrust fault (Signorelli et al. 
1996; Baltazar and Zucchetti 2007; Moreira et al. 2016). In the NLC block, this unit is present in the Gandarela, Rio Acima, Capanema, and Rio de Pedras quadrangles (Araújo et al. 2020a, b; Cavalcanti et al. 2020c; Freitas et al. 2020a, c), and contains three members named, from base to top, as Chica Dona, Jaguara (Signorelli et al. 1996), and Capanema (Silva et al. 1996). In the SB block, this formation comprises two subunits named Chica Dona and Córrego do Engenho members, that crop out in the Capanema, Conceição do Rio Acima and Catas Altas quadrangles (Freitas et al. 2020a; Ferreira et al. 2020a, b).

\subsubsection{Chica Dona Member}

Zucchetti et al. (2000c) defined the Chica Dona Member's type-section from outcrops situated at the homonymous waterfall.
The member consists of alternating layers of fine-grained sericitic metaquartzarenites (Fig. 17A), metagreywackes, and monomictic to polymictic metaconglomerates. The metaquartzarenites and metagreywackes are the thickest rock packages that, locally, have fining-upward cycles, with conglomeratic rocks at the base and sericite-quartz schist at the top. These rocks may also be planar stratified and tabular cross-bedded.

The metaquartzarenites (Fig. 17B) predominate and have variable proportions of sericite, chlorite, chloritoid, kyanite, and rutile. The metagreywackes comprise coarse- to finegrained (chloritoid)-chlorite-sericite-quartz schists containing traces of carbonate, rutile, albite and opaque minerals. The metaconglomerates occur as $\mathrm{cm}$ - to m-thick lenses, and can either be clast- or matrix-supported. The conglomerates'
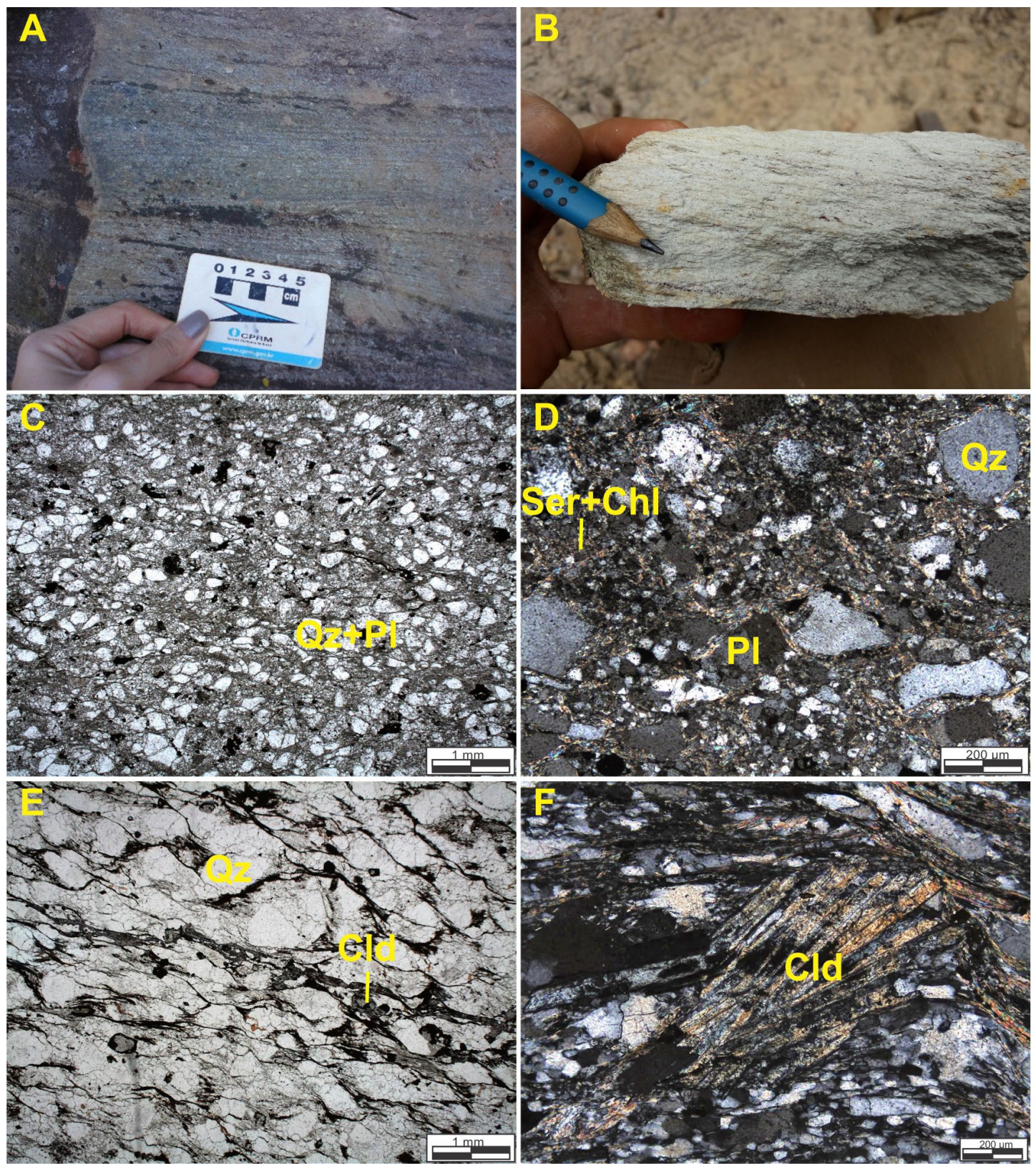

FIGURE 15. Palmital Formation. (A) - Hand-sample of a metagreywacke with tabular cross-bedding. (B) - Hand sample of mica-quartz schist. (C) - Photomicrography of metagreywacke composed of quartz clasts in a fine-grained mica matrix (PPL). (D) - Detailed photomicrography of metagreywacke with angular to subrounded quartz porphyroclasts. (CPL). (E) - Photomicrography of quartzite with anastomosed chlorite and sericite stringers around stretched quartz clasts $(\mathrm{PPL})$. (F) - Photomicrography of radial chloritoid crystals $(\mathrm{CPL})$. Abbreviations: $\mathrm{Qz}=$ quartz; $\mathrm{PI}=$ plagioclase $;$ Ser = sericite; $\mathrm{Chl}=$ chlorite; $\mathrm{Cld}=$ chloritoid . 

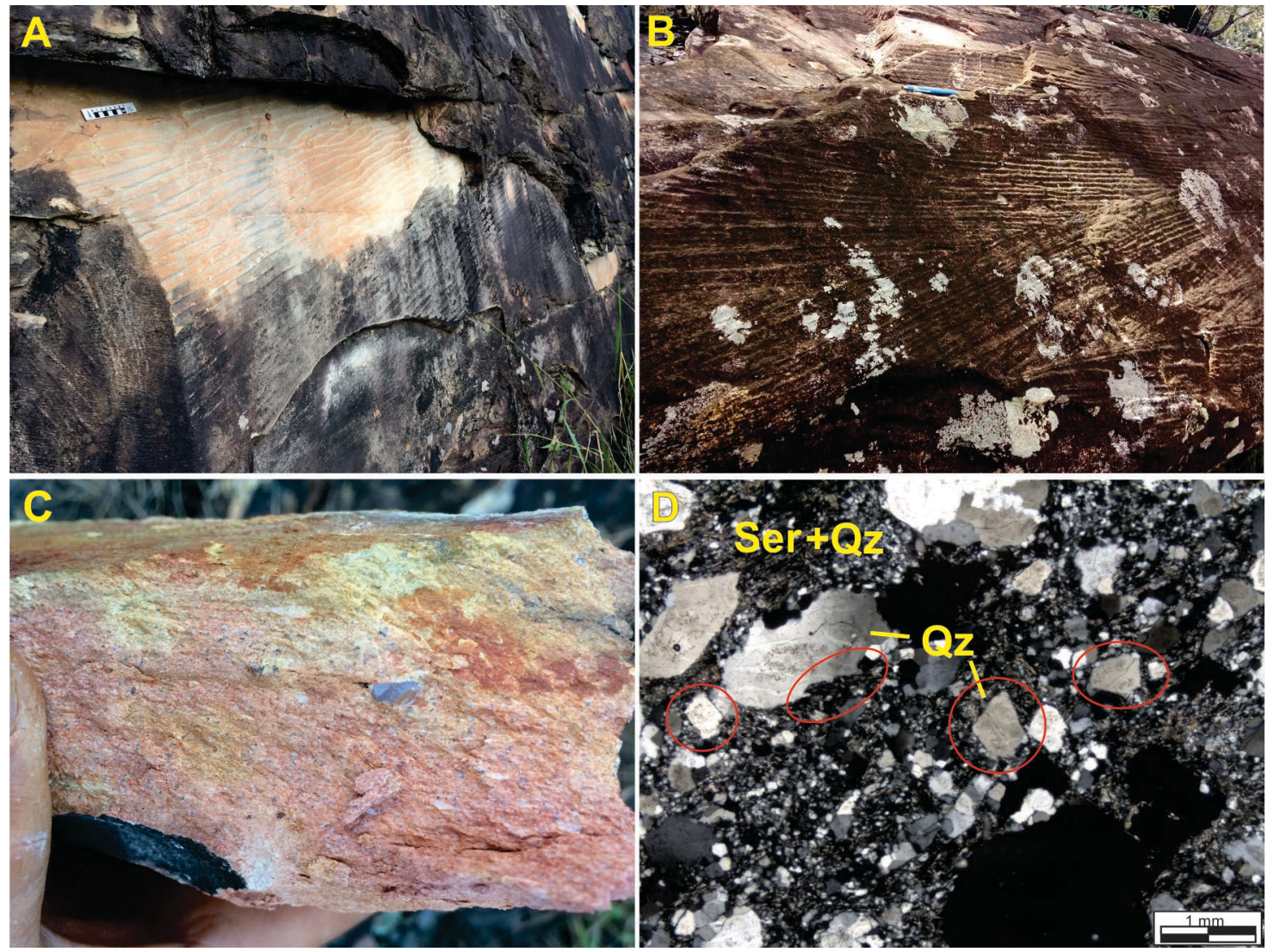

FIGURE 16. Andaimes Formation. (A) - Outcrop of metasandstone with asymmetric ripple marks; bedding is vertical. (B) - Outcrop of metasandstone with herringbone cross-bedding. (C) - Hand sample of microconglomerate with blue quartz crystal. (D) - Photomicrography of a microconglomerate with bipyramidal quartz crystals and embayment texture (red circles) in a quartz-sericite matrix (CPL). Abbreviations: $Q z$ = quartz; Ser $=$ sericite.

clasts have up to $30 \mathrm{~cm}$ in diameter, subangular to subrounded, and variable compositions, such as iron formation, metachert, carbonaceous phyllite, quartz vein, quartzite, basic rock, and granite. The matrix is sandy, commonly ferruginous, and composed of quartz, sericite, and minor proportions of biotite, opaque minerals, and chloritoid porphyroblasts. Various preserved primary features comprise tabular and trough cross-bedding, graded bedding, cut-and-fill structures, and sole marks (Signorelli et al. 1996; Zucchetti and Baltazar 2000; Moreira et al. 2016).

\subsubsection{Jaguara Member}

The Jaguara Member type-area is a homonymous ridge, which exposes the unit's most representative outcrops (Signorelli et al. 1996; Zucchetti et al. 2000c). This member consists of coarse-grained to microconglomeratic quartzites (Fig. 17E), with coarse-grained smoky quartz clasts in a quartz-sericite matrix (Fig. 17F). Chlorite and radial aggregates of chloritoid occur subordinately. Fine-grained quartzites and metagreywackes are more frequent in the southeastern part of this unit. They are interbedded with decimeter-thick finingupward cycles of microconglomerates and quartzites. Thin lenses of polimitic metaconglomerate are rare layers within the quartzites and contain clasts of schist, metachert, quartz vein, and carbonaceous phyllite. Preserved sedimentary structures include tabular and trough cross-bedding and graded bedding. The contacts with the Chica Dona and Capanema members are transitional.

\subsubsection{Capanema Member}

The Capanema Member occurs only at the extreme southeast of the Vargem do Lima syncline. It consists of fine-grained metasedimentary rocks that are considered a lateral facies of the other members of the Casa Forte Formation. The most representative outcrops occur near the Capanema mine, along the road from the mine to highway BR-356 (Silva et al. 1996). Its characteristic rock is a silvery to red package of quartz-sericite schist (Fig. 17G), interbedded with fine-grained metagreywacke layers, arranged in rhythmic cycles. Local preserved primary features comprise tabular, trough cross-bedding, and graded bedding. The schist usually displays a crenulation cleavage (Fig. 17H). Although rare, decimetric layers of conglomeratic quartzites to metaconglomerates can be found in this sequence. They contain stretched pebbles of metachert and quartzites. Chloritoid, kyanite, and chlorite are lesser minerals.

\subsubsection{Córrego do Engenho Member}

The type-area of the Córrego do Engenho Member is near the homonymous creek, southern region of the SB block (Silva et al. 1996). It is also well exposed along both edges of the Caraça Ridge, cropping out as N-S ranges. This member has gradational contact with the Chica Dona Member and tectonic contact with the Minas Supergroup. Rocks of this unit include metagreywackes and metaquartzarenites (Fig. 17C) and subordinate layers of matrix-supported metaconglomerates. Small- to medium-scale cross-bedding and graded-bedding 

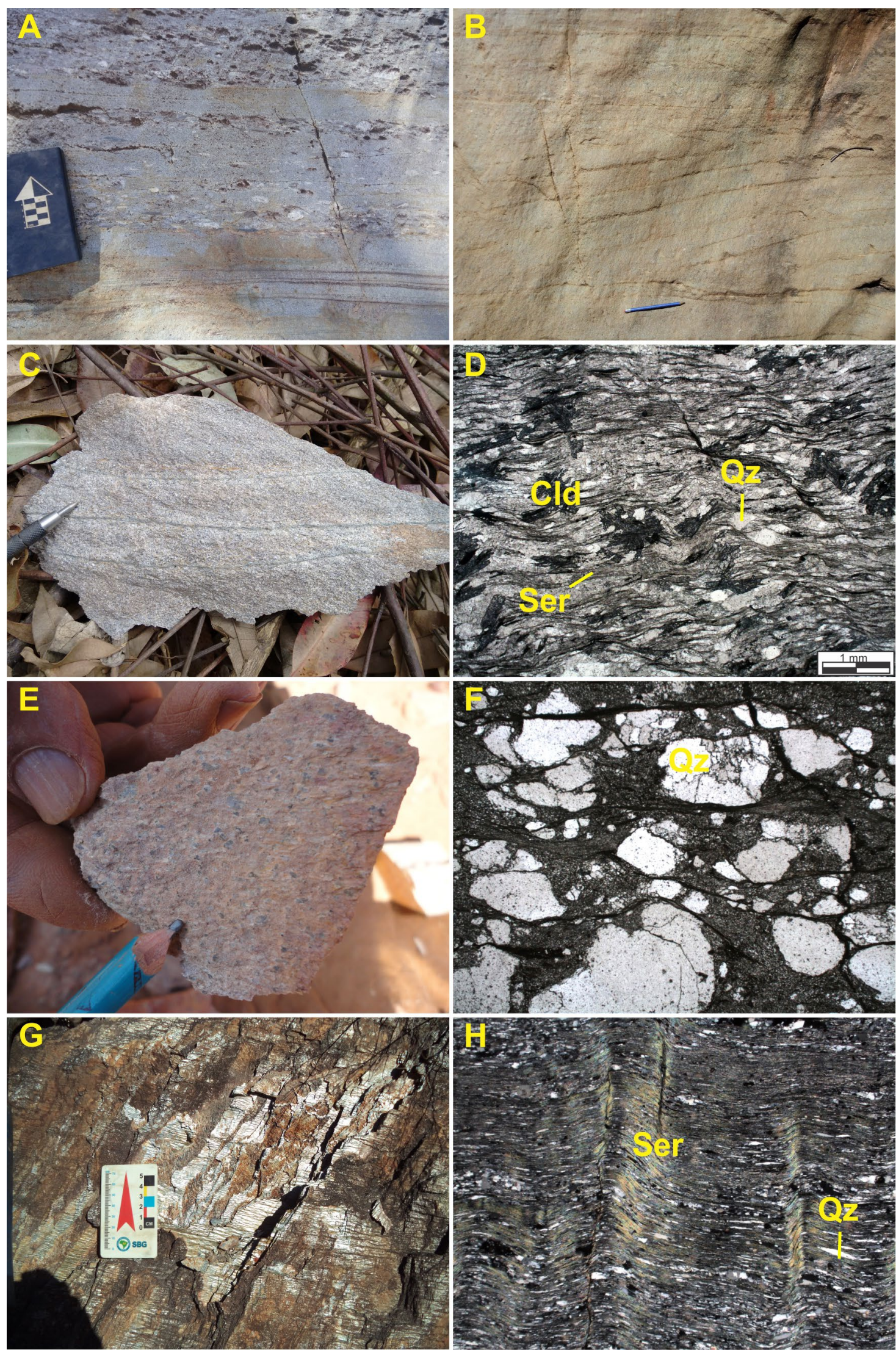

FIGURE 17. Casa Forte Formation: Chica Dona Member: (A) - Outcrop of polimitic metaconglomerate. (B) - Outcrop of metaquartzarenite with preserved tabular cross-bedding. Córrego do Engenho Member: (C) - Hand-sample of fine-grained micaceous quartzite with centimetric layers of sericite. (D) - Photomicrography of crenulated chloritoid-sericite-quartz schist (metagreywacke) (PPL). Jaguara Member: (E) - Hand sample and $(F)$ - Photomicrography of conglomeratic metaquartzarenite $(P P L)$. Capanema Member: $(G)$ - Outcrop of quartz-sericite schist with crenulation cleavage; $(\mathrm{H})$ - Photomicrography of quartz-sericite-schist with crenulation cleavage $(\mathrm{CPL})$. Abbreviations: Cld = chloritoid; $\mathrm{Qz}=$ quartz; Ser = sericite 
also occur. Its lithotypes comprise chloritoid quartzites (Fig. 17D), sericite quartzites, (chlorite)-sericite-quartz schist and biotite-sericite-quartz schist. Quartz porphyroclasts are commonly recrystallized and stretched along the foliation. Less abundant phases comprise rutile, plagioclase, biotite, kyanite, zircon, titanite, tourmaline, and opaque minerals.

\section{Magmatic intrusions}

\subsection{Córrego dos Boiadeiros intrusive suite}

The Córrego dos Boiadeiros intrusive suite outcrops westwards of the city of Rio Acima, in the Rio Acima and São Sebastião das Águas Claras quadrangles (Cavalcanti et al. 2020 c, e). The suite is an association of metaultrabasic and metabasic rocks that forms an elongate $\mathrm{N}$-S-trending body of about $4 \mathrm{~km}$ long and up to 2-3 km wide in its central portion. Drake and Morgan (1980) interpret it as an autochthonous part of an ophiolite, whereas Padilha (1984) considers it a komatiitic sequence. Schrank et al. (1990) and Costa (1995) propose that the suite is intrusive at the base of the Nova Lima Group (Fig. 3), due to its plutonic to subvolcanic character, an interpretation that we adopt.

The suite is in tectonic contact with the metabasic and metapelitic rocks of the Nova Lima Group to the north, east, southeast, and west, and with the Minas Supergroup, to the southwest (Fig. 2). The best exposures of this unit are in the Pedras Congonhas and Extramil mines.

Metaultrabasic rocks prevail in the Córrego dos Boiadeiros suite and preferably outcrop in its central portion (Fig. 2). The main lithotypes are serpentinites, steatites, talc schist, chlorite-tremolite schist, and tremolite-serpentinite granofels (Fernandes 2016). Serpentinites (Figs. 18A, 18G) are the dominant rocks and possibly derived from different protoliths, such as dunites, orthopyroxenites, and peridotites. The metadunites are light gray, intensely serpentinized (Fig. 18B), and exhibits cumulate textures. Serpentine has mesh or hourglass textures and occurs as pseudomorphs after olivine, rimmed with intercumulus magnetite crystals (Fig. 18E). Metaorthopyroxenites are also intensely serpentinized and show cumulate textures, with pseudomorphs of serpentine after orthopyroxene, set in a serpentine-chlorite matrix (Fig. 18F). The most deformed serpentinites lack relic textures and comprise an association of chrysotile and antigorite, with less carbonate, talc, magnesite, and magnetite (Pinheiro and Cavalcanti 2018). Magnesite veins are common in the most deformed specimens (Fig. 18A). Steatite and talc schist (Fig. 18C) are associated with serpentinites, and its abundance increases towards the borders of the intrusion. Besides talc, other subordinate phases comprise carbonate, tremolite, and serpentine. The tremoliteserpentine granofels contain pseudomorphs of serpentine, tremolite, and talc of granular and prismatic shapes, probably formed after olivine and pyroxene (Fernandes 2016).

Metabasic rocks are subordinate and occur as rims of the intrusion (Fig. 2). They consist of clinozoisite-actinolite granofels and metagabbro. In the clinozoisite-actinolite granofels, the epidote derived from an intense alteration of plagioclase. Chlorite, plagioclase, quartz, and titanite occur in minor proportions (Fernandes 2016). The metagabbros (Figs. 18D, 18H) are often strongly metasomatized, which hinders the identification of the original mineral assembly. These rocks contain sericite, epidote, serpentine, and amphibole, probable pseudomorphs after plagioclase and pyroxene.

\subsection{Felsic to intermediate volcanism}

Layers of intermediate to acid metavolcanic and metavolcaniclastic rocks (Figs. 19A, 19B) outcrop to the south of the Morro Vermelho village, in the Caeté quadrangle (Araújo et al. 2020a), in the NLC block. They occur as thin N-Strending almond-shaped layers in tectonic contact with the Roça Grande Member of the Morro Vermelho Formation. They consist of metagreywackes with less than $2 \mathrm{~mm}$ plagioclase and quartz porphyroclasts (Fig. 19C) in very fine-grained quartz and plagioclase matrix with minor sericite, biotite, and magnetite. Plagioclase porphyroclasts can internally be zoned and are commonly euhedral to subhedral, indicating reduced transportation or reworking. In hand samples, quartz grains are grayish-blue. The presence of lithic fragments of felsic rocks is suggested by imbricated plagioclase crystals viewed under the microscope (Fig. 19D). Due to strong mylonitization, quartz grains are recrystallized, stretched, and do not preserve typical primary features of volcanic quartz grains.

These rocks may be easily misinterpreted with the greenstone belt volcanism. However, a U-Pb concordia age of $2,677 \pm 10$ Ma was obtained for a dacitic metavolcaniclastic rock belonging to these layers (Araújo and Magalhães 2017). This age is considerably younger than the ones obtained for the Nova Lima Group (e.g., Machado et al. 1989, 1992, 1996; Noce et al. 2005). While the last match the Rio das Velhas II magmatic event (2,800-2,770 Ma) as reported by Lana et al. (2013), the former match the Mamona I event $(2,750-2,680)$ by Farina et al. (2015). Also, the $2.68 \mathrm{Ga}$ age is similar to the $2.65 \mathrm{Ga}$ age obtained by Cabral et al. (2012) from metavolcanic rocks interbedded with itabirites of the Cauê Formation (Minas Supergroup). Araújo and Magalhães (2017) proposed two different scenarios to explain this younger dacitic rock. It could belong to an upper unit of the RVGB, thus representing a final volcanism during the closure of the Rio das Velhas basin, at least partially synchronous with the opening of the Minas Basin. Alternatively, this volcanic activity occurred after the closure of the Rio das Velhas basin and affected both the Rio das Velhas and Minas supergroups. In this paper, we follow the second hypothesis.

\subsection{Basic dikes}

Basic dikes and sills crosscut, parallel to discordant the greenstone belt sequence in the Santa Bárbara block with an NNE-SSW trend and SE dip (Figs 2, 3). Lima (2012) classifies these rocks as metagabbros that underwent variable degrees of chloritic, carbonatic and sericitic hydrothermal alteration and may have association with the gold mineralization (Roncato et al. 2015 and references therein).

\section{Discussion}

\subsection{A comparative approach: volcanic architecture and sedimentary depositional models}

The exposed area of the RVGB comprises about $70 \%$ of metasedimentary rocks and $30 \%$ of metavolcanic rocks, indicating that the former are better preserved than the latter. This abundance of sedimentary rocks distinguishes 

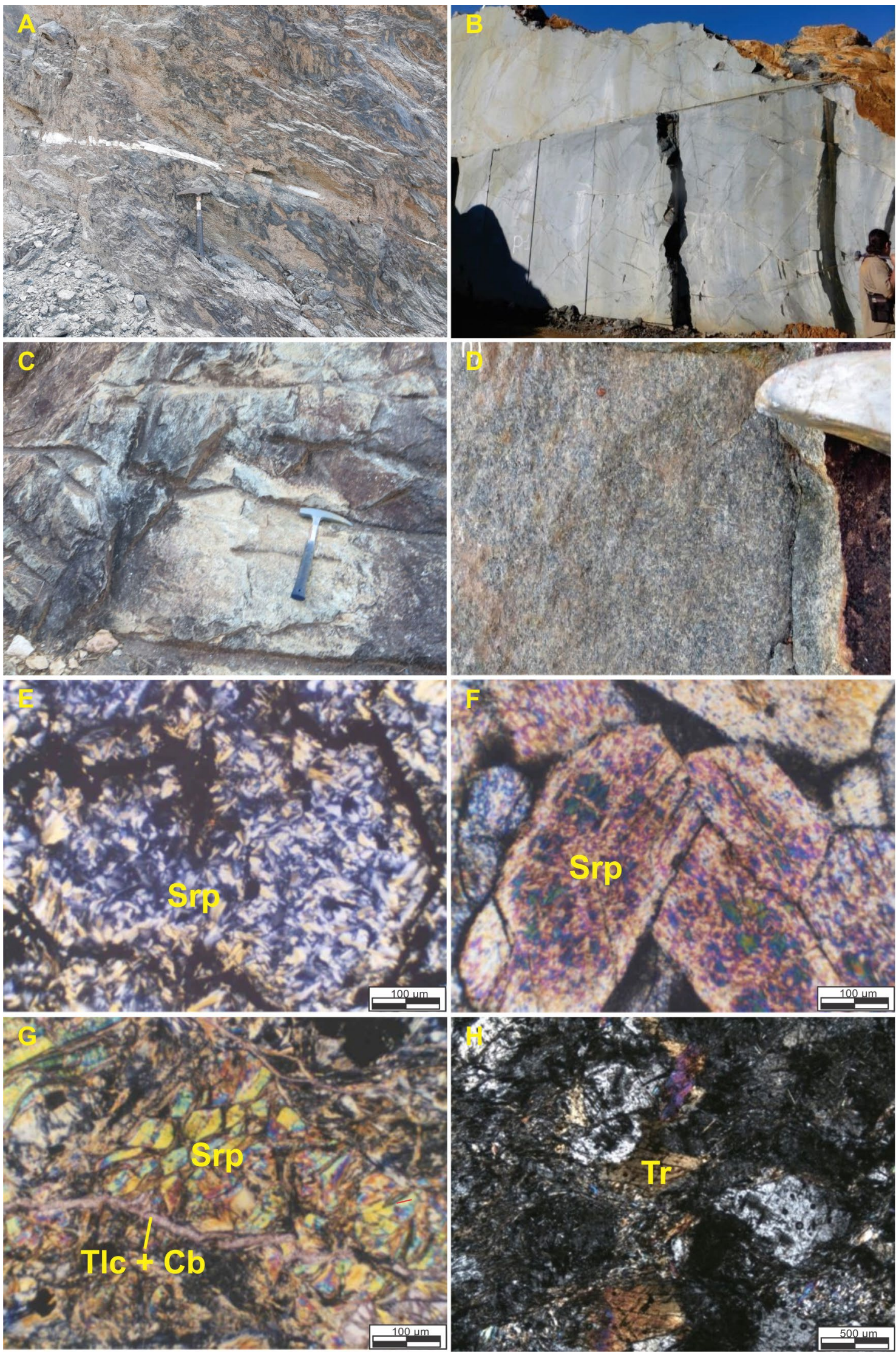

FIGURE 18. Representative rocks of the Córrego dos Boiadeiros intrusive suite. (A) - Outcrop of serpentinite cut by magnesite veins. (B) - Outcrop of metadunite. (C) - Outcrop of talc schist. (D) - Outcrop of metagabbro. (E) - Photomicrography of metadunite showing pseudomorphs of serpentine after cumulate olivine, with magnetite representing intercumulus material (CPL). (F) - Photomicrography of metaorthopyroxenite with prismatic pseudomorphs of serpentine after orthopyroxene (CPL). (G) - Photomicrography of serpentinite with serpentine pseudomorphs after olivine and fractures filled with talc and carbonate $(\mathrm{CPL})$. $(\mathrm{H})$ - Photomicrography of metasomatized metagabbro $(\mathrm{CPL})$. Abbreviations: $\mathrm{Srp}=$ serpentine; $\mathrm{Tlc}=$ talc $; \mathrm{Cb}=$ carbonate; $\mathrm{Tr}=$ tremolite 

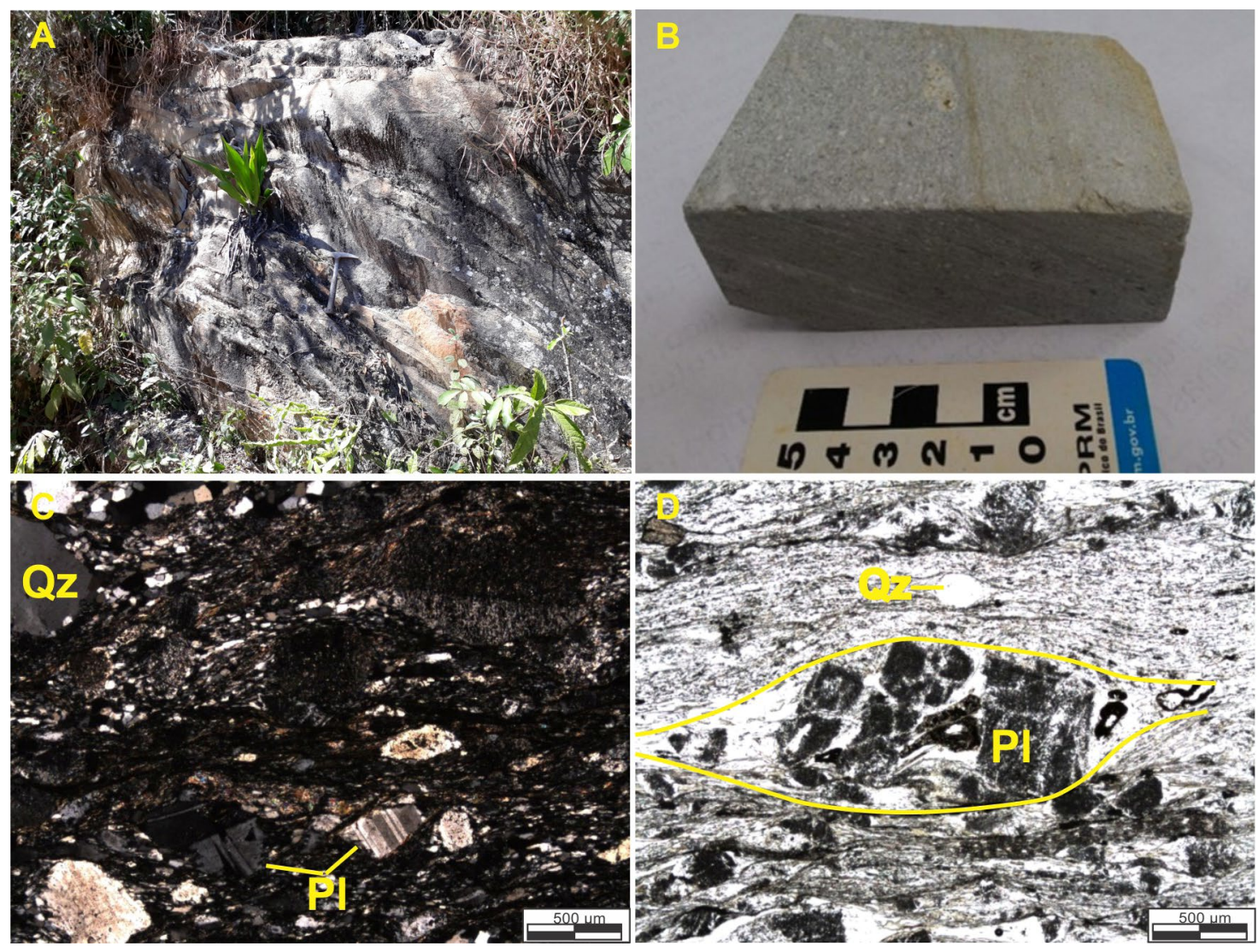

FIGURE 19. Volcaniclastic rocks of the felsic rocks unit. (A) - Outcrop, and (B) - Hand specimen. (C) - Photomicrography of quartz and plagioclase porphyroclasts $(C P L)$. (D) - Photomicrography of imbricated and strongly sericitized plagioclase crystals, in a probable lithic fragment (PPL). Abbreviations: Qz = quartz; PI = plagioclase.

it from other worldwide Archean terrains, such as the Superior Province, Kaapvaal, and Pilbara cratons (e.g., Anhaeusser 2014).

In this section, we discuss the sedimentary and volcanic depositional environments of the RVGB rock protoliths, relying mainly on the field and petrographic criteria, in addition to published lithogeochemical and geochronological information. Schematic models of these volcanic and sedimentary depositional environments and their evolution over time are shown in Fig. 20.

Due to the complex geological evolution of the three blocks and the remarkable differences between their supracrustal rock sequences, evolution and tectonic models will rest under debate until the rise of new field data added with the advance of technological methods, being beyond the scope of this paper.

\subsection{Ultrabasic and basic volcanism}

\subsubsection{Quebra Osso Group}

The basal section of the greenstone belt sequence consists of ultrabasic metavolcanic rocks of the Quebra Osso Group, cropping out only in the SB block. They are metakomatiites with cumulate and spinifex textures, pillow lavas, and minor volcaniclastic deposits. Thin lenses of clastochemical metasedimentary rocks are minor interlayers in the metavolcanic sequence.

Historically, these basal ultrabasic rocks are interpreted as representing a former oceanic crust (see Zucchetti 1998; Zucchetti et al. 2000a, b, c; Baltazar and Zucchetti 2007).
However, through field and geochemical data, Ferreira et al. (2020e) report that the ultrabasic lavas of the Quebra Osso Group underwent crustal contamination, and the komatiites' eruption occurred along fissures onto the Santa Bárbara Complex sialic crust (Fig. 20A-I). They erupted in a submarine environment, as evidenced by pillow lavas, and the association with the chemical sedimentary rocks (e.g., McPhie et al. 1993). The successive facies are part of a large komatiite flow field, and the predominance of olivine cumulates suggests channelized lava flows, with subordinate marginal spinifextextured lava flows, related to breakouts of lava from the main pathway (Figs. 20A-II, III; Ferreira et al. 2020e).

\subsubsection{Nova Lima Group}

Basic metavolcanic rocks of the Nova Lima Group crop out in the SB and NLC blocks, while the latter also records the ultrabasic lavas of this group.

In the SB block, the basic volcanism is very restricted, represented by the Vigário da Vara Formation. It comprises massive to pillowed, locally variolitic metabasalts interbedded with thin lenses of Algoma-type banded iron formations, indicating a subaqueous environment of eruption and deposition environment (Fig. 20B-I). Whole-rock analyses reported by Zucchetti (1998) and Silva (2000) for the Vigário da Vara metabasalts reveal that their composition is compatible with the modern MORB type volcanic rocks. Nevertheless, the eruption of the basic volcanic successions and the relationships with the ultrabasic volcanism of the Quebra Osso Group and with the extensive volcanism of the NLC block are still poorly understood. 

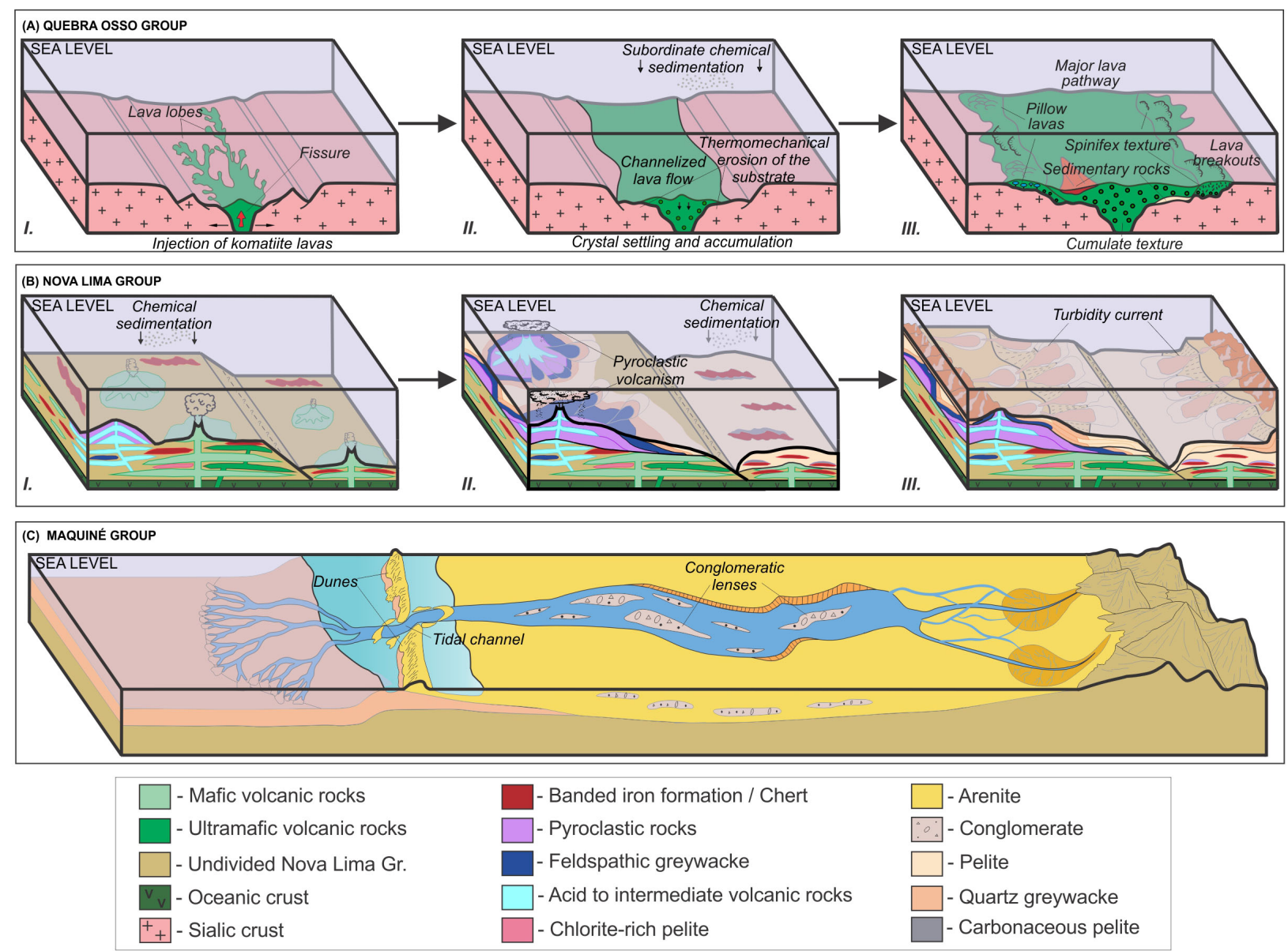

FIGURE 20. Volcanic architecture and depositional models for the Rio das Velhas greenstone belt. (A) - Quebra Osso Group: (I) Komatiite lavas' fissure eruption, in a submarine environment. (II) Thermomechanical erosion of the substrate, channelization of lavas and beginning of crystal settling and accumulation, with subordinate chemical sedimentation. (III) Formation of cumulate komatiites, in the major lava pathway, with subordinate spinifex komatiites, pillowed lavas and sedimentary rocks in the marginal flows. (B) - Nova Lima Group: (I) Predominantly basic volcanism in the lower portion. The Ouro Fino and Morro Vermelho formations are represented on the left, by the intercalation of volcanic rocks of different compositions, volcaniclastic, clastic and chemical sedimentary rocks. Basic volcanic rocks interbedded with BIF of the Vigário da Vara Formation are shown on the right. (II) Felsic to intermediate volcanism with widespread pyroclastic and debris flows on the left, illustrating the Mestre Caetano Formation. On the right, clasto-chemical sedimentation of the Santa Quitéria Formation. (III) Deposition of clastic sediments by turbidity currents representing the thick sedimentary packages of the upper sections, in the Córrego do Sítio, Ribeirão do Brumado, Fazenda Velha, Córrego da Paina, and Pau D'Óleo formations. (C) - Maquiné Group: deposition of alluvial-fluvial sediments with conglomerates lenses in channels of the Casa Forte Formation, the coastal environment of the Andaimes Formation with tidal channel and dunes, and the shallow to coastal marine environment of the Palmital Formation.

In the NLC block, the ultrabasic and basic rocks are closely associated, because they occur interbedded in the Ouro Fino Formation. However, the ultrabasic rocks are volumetrically subordinate and strongly serpentinized. Concerning the basic rocks, they are also represented by the Morro Vermelho Formation, being the most abundant volcanic rocks of this block. Metabasalts of both units are formed predominantly by massive, and subordinately pillowed flows. Their strong association with chemical sediments (BIF and chert) suggests that they deposited in a subaqueous environment (Fig. 20B-I).

The ultrabasic and basic metavolcanic rocks occur in the Caeté and Nova Lima areas, lying respectively at the NLC block's eastern and western edges (Fig. 2). The distribution of these rocks in the region and their relationships with the overlaying volcaniclastic and sedimentary rocks suggest that both areas had volcanic centers during the greenstone belt's early stages of evolution. The volcanic pile reached maximum thickness near the volcanic centers, decreasing towards the center of the block.

The chemical compositions of those rocks are similar to komatiitic basalts, high-Mg tholeiitic basalts, and highFe tholeiitic basalts (Zucchetti 1998; Silva 2000). The same authors describe that the metabasalts of the NLC block correlate with the MORB pattern, and are related to a mantle plume in a submarine plateau environment, similar to the Vigário da Vara Formation rocks of the SB block. Baltazar and Zucchetti (2007) suggest that the ultrabasic-basic association erupted in a seafloor spreading environment. However, the authors also pointed out that the more evolved basalts may have formed in an island arc setting. In contrast, this is also the environment proposed by Verma et al. (2017) for the high$\mathrm{Mg}$ basalts. Therefore, the tectonic environment of these rocks is not yet a consensus. 


\subsection{Acid to intermediate volcanic and volcaniclastic rocks}

The occurrence of acid metavolcanic rocks is well recorded only in the NLC block, where they are associated with almost the entire sequence (Fig. 3). Volcanism of this nature is so far unknown in the SB and SBT blocks, although, sparse volcanogenic detritus (e.g., quartz with corrosion features) occur in the sedimentary sequences.

Acid/intermediate metavolcanic and metavolcaniclastic rocks occur interlayered with the metaultrabasic/basic sequence of the Ouro Fino and Morro Vermelho formations (Figs. 3, 8E, 8F, 9E and 9F). The contact between the ultrabasic/ basic and the acid/intermediate rocks is not always exposed. However, their interlayered relationships suggest that they are coeval (Fig. 20B-I). Silva (2000) describes that the chemical composition of these rocks is dacitic, subordinately rhyolitic, similar to those of an arc-related environment.

Isotopic $\mathrm{U}-\mathrm{Pb}$ zircon data from the acid metavolcanic and metavolcaniclastic rocks of the Morro Vermelho Formation obtained by Machado et al. (1989) and Noce et al. (2005) yielded crystallization ages of 2,776 \pm 23 and 2,751 $\pm 9 \mathrm{Ma}$. These ages can be related to the Rio das Velhas II magmatic event, representing the final stage of TTG crust production in the QF (e.g., Romano et al. 2013; Lana et al. 2013).

In the intermediate section of the Nova Lima Group, a package of acid and intermediate volcaniclastic rocks characterizes the Mestre Caetano Formation (Fig. 10). The occurrence of metapyroclastic rocks, such as metaagglomerates and metatuffs, concentrated in the Ribeirão Vermelho Member, indicates that they derived from explosive volcanic eruptions. Thus, the pyroclastic protoliths of the Mestre Caetano Formation deposited as thin layers adjacent to the eruptive centers. Simultaneously, due to the high topographic relief associated with the cone volcano, the pyroclastic sediments were eroded, transported, and deposited as turbidites and debris-flow characteristics of this unit (Fig. 20B-II). The intercalation of chemical sediments within the detrital ones, even subordinated, suggests that the resedimentation of the greywackes occurred in a subaqueous environment.

Whole-rock geochemical data from the metapyroclastic rocks obtained by Silva (2000) revealed that their composition is dacitic and andesitic. They are similar to the acid layers of the Ouro Fino and Morro Vermelho formations of the lower section of the Nova Lima Group. The U-Pb zircon ages obtained by Noce et al. (2005) for a volcanogenic metagreywacke and a meta-agglomerate from the Mestre Caetano Formation yielded 2,792 \pm 11 and $2,773 \pm 7 \mathrm{Ma}$ ages, respectively. These data suggest that the acid and intermediate volcanic rocks of the lower and intermediate sections of the Nova Lima Group formed during the same magmatic event(s).

\subsection{Sedimentary rocks}

\subsubsection{Nova Lima Group}

The Nova Lima Group contains several layers of clastic and chemical metasedimentary rocks that predominate in the stratigraphic sequence of the RVGB. Thick metasedimentary layers cover the volcanic-derived units in the NLC and SB blocks and mark the end of the magmatic activity. In the SBT block, the metasedimentary rocks represent the entire stratigraphic package. Also, the metasedimentary rocks are frequently interbedded with metavolcanic rocks in the basal section of the greenstone belt, particularly in the NLC block (Fig. 3). However, only a few studies centered in small areas were dedicated to determining the characteristics of these metasedimentary assemblages (e.g., Roncato 2016; Freitas et al. 2019).

The chemical metasedimentary rocks, such as the BIFs and metachert, are common in the basal and intermediate units of the Nova Lima Group (Figs. 20B-I, II). In the NLC block, they occur mainly interbedded with the ultrabasic and basic metavolcanic rocks of the Ouro Fino and Morro Vermelho formations. The chemical rocks also occur, but are less frequent, in contact with metavolcaniclastic and clastic metasedimentary rocks. In the SB block, thin lenses of these rocks occur interlayered with the volcanic sequences of the Vigário da Vara Formation. Chemical rocks also constitute thick packages in the Santa Quiteria Formation, interbedded with clastic metasedimentary rocks (Figs. 20B-II). In the upper sections of the Nova Lima Group, the Córrego do Sítio Formation has minor intercalations of BIF. In the SBT block, thin layers of BIFs and tourmalinites are restricted to the Córrego da Paina Formation.

Detailed studies by Araújo and Lobato (2019) detected mineralogical and geochemical differences between the BIFs of the NLC and the SB blocks, which implies different depositional environments. In the NLC block, the chemical metasedimentary rocks include metachert, carbonate-rich, and magnetite-rich BIF layers preferentially occurring near volcanic centers in a deep-sea environment. In contrast, in the SB block, the BIFs occur interbedded with clastic metasedimentary rocks. They usually have a significant mineralogical variability including magnetite, carbonate, and several silicates, such as stilpnomelane, chlorite, and iron-rich biotite. Geochemical data obtained for these BIFs suggest low hydrothermal activity and a remarkable contribution of detrital silicates. This difference points to a deposition in high-energy environments such as submarine fans that are not favorable for chemical sedimentation. In this setting, eustatic variations seem to be crucial for BIF deposition. During sea-level transgressive events, when high levels of seawater avoid terrigenous input, the environment becomes stable and favorable for BIF's formation (Araújo and Lobato 2019).

The nature of the clastic sedimentation of the lower section of a greenstone belt sequence is strongly controlled by volcanism styles and cyclicity (Lowe 1980). The predominance of ultrabasic and basic volcanism that normally forms low relief, shield-type volcanoes, tend to produce a low volume of clastic loads. However, in the NLC block the activity of the acid volcanism tends to form relatively steep cone-shaped volcanoes and produce large volumes of debris (Lowe 1980). The contribution of clastic loads increases from the Ouro Fino to Morro Vermelho formations, suggesting that the clastic intervals between ultrabasic/basic flows grew towards the top of these units. At the basal section, where the sources for sediments were predominantly ultrabasic/basic rocks, the resulting sediments are now represented by the common chlorite-rich metapelites, besides the carbonaceous phyllite and metagreywackes (Figs. 3, 20B-I).

An intense acid/intermediate volcanic activity is well recorded in the intermediate section of the Nova Lima Group, 
represented by the Mestre Caetano Formation of the NLC block. The cone-shaped volcanoes were an essential source of clastic loads, and its hilly relief provided an ideal steep topography to trigger avalanches, which formed submarinefans. In effect, Zucchetti et al. (2000a), Noce et al. (2005), and Baltazar and Zucchetti (2007) suggest that the protoliths of the metagreywackes, metasandstones, and meta-argilites of this unit deposited by turbidity currents in a submarine environment (Fig. 20B-II).

The clastic metasedimentary rocks prevail in the Nova Lima Group's upper sections in the three tectono-stratigraphic blocks. They are the main components of the following stratigraphic units: Ribeirão do Brumado (NLC block), Córrego do Sítio (SB block), and Córrego da Paina, Fazenda Velha and Pau D'Óleo (SBT block). Metagreywackes and metapelites are the predominant lithotypes and frequently occur as depositional cycles with incomplete Bouma sequences derived from turbidity currents (Fig. 20B-III), as interpreted by Zucchetti et al. (2000c), Baltazar and Zucchetti (2007), Roncato et al. (2015), and Sepulveda (2020). According to Lowe (1980) and McLennan (1984), the greywacke sedimentation in Archaean turbidites often contains a mixture of epiclastic and volcaniclastic debris derived from subaqueous slopes within tectonically active basins. These events seem to be the main sedimentary dynamic processes of this phase of the RVGB evolution. These rocks document a significant waning of the volcanic activity, followed by the greenstone belt uplift and plutonism.

The prevalence of preserved metasedimentary over metavolcanic rocks is an important feature of the RVGB. It is possible that the ultrabasic/basic volcanism was less intense, when compared with other greenstone belts (e.g., Barberton, Abitibi, Munro; Anhaeusser 2014). However, the frequent metasedimentary rocks interbedded with metavolcanic rocks at the basal section suggest that an active tectonism could take place concomitant to volcanism. As a consequence, there was a substantial reworking of these rocks, with erosion of the volcanic pile and deposition of large sedimentary packages. In addition, part of the basal metavolcanic rocks may still be covered by the thick metasedimentary sequence.

Whole-rock geochemical studies of metasedimentary rocks from the NLC and SB blocks by Baltazar and Zucchetti (2007) indicate a dominant acid source for the former and mixed acidbasic for the latter. In the NLC block, the main source for the clastic load seems to have been by the erosion of high-standing volcanic edifices, with deposition of the thick submarine clastic package by turbidity currents and debris flow of the Ribeirão do Brumado Formation (Fig. 20B-III). The few and thin layers of pyroclastic and volcaniclastic rocks interbedded in this unit indicates that the volcanic activity decreased considerably, without ceasing completely. In the SB block, the clastic metasedimentary rocks of the Córrego do Sítio Formation received a significant clastic load from ultrabasic-basic rocks of the greenstone belt mixed with detritus from the TTG basement (Roncato 2016). On the other hand, the lithogeochemical data from metasedimentary rocks of the Nova Lima Group in the SBT block indicate mixing of clastic loads derived from TTG granite-gneisses and tholeiitic basalts, interpreted as the result of the erosion of the basement and the basal formations of the Nova Lima Group (Freitas 2019).

Maximum depositional ages for the top of the Nova Lima Group are attributed to ca. 2,750 Ma by Coelho (2015), and ca. 2,680 Ma by Dopico et al. (2017).

\subsubsection{Maquiné Group}

The upper section of the RVGB consists of metasedimentary rocks of the Maquiné Group, subdivided into the Palmital, Casa Forte, and Andaimes formations. The Maquiné Group overlies the Nova Lima Group, and the contact between them is either an unconformity, conformable or gradational, depending on the outcrop location (Baltazar and Zucchetti 2007; Angeli 2016). The metasedimentary sequence of the group is very similar in the NLC and SB blocks, and the Palmital and Casa Forte formations are present in both blocks. Still, in the SBT block, the group is represented only by the Andaimes Formation.

The Palmital Formation contains fine to medium-grained metagreywackes and quartzites, with preserved sedimentary features, such as tabular and trough cross-bedding, deposited in a shallow to coastal marine environment (Signorelli et al. 1996; Malouf and Corrêa Neto 1996; Zucchetti et al 2000c; Baltazar and Zucchetti 2007). The Andaimes Formation consists of micaceous metasandstones, metasiltstones, and microconglomerates, with well-preserved ripple marks and herringbone cross-stratification, deposited in a coastal environment, associated with tidal plain and dunes (Pedreira 1998). The Casa Forte Formation consists of fine to coarsegrained quartzites, metaconglomerates and subordinated metapelites, related to a braided river environment associated with an alluvial-fluvial sedimentary system (Pedreira 1995, 1998; Angeli 2016). The conglomerates lenses represent channel deposits (Fig. 20C).

A retroarc foreland-basin environment has been attributed to the Maquiné Group (Dorr II 1969; Signorelli et al. 1996; Golia 1997; Baltazar and Zucchetti 2007; Moreira et al. 2016). Provenance studies for the Palmital Formation (Moreira et al. 2016) suggest that its sedimentary rocks derived from the erosion of syn-orogenic rocks and less from the preexisting continental crust. Zircon grains from the Casa Forte Formation are consistent with deposition in a convergent margin setting. In the Vargem do Lima syncline, quartzites, metaconglomerates, and metaphyllites of the Maquiné Group yielded a maximum depositional age of ca. 2,730 Ma. The authors suggest that the sedimentary source-area and environmental energy of the Maquiné Group changed from its base to the top, as indicated by drastic differences in the composition of its rock sequence and by coarsening upward due to a fast exhumation of the source-area.

Isotopic U-Pb SHRIMP data of detrital zircon grains from the Andaimes Formation metasandstone yielded a 2,745 $\pm 6 \mathrm{Ma}$ age, interpreted as the maximum depositional age (Hartmann et al. 2006).

\section{Conclusions}

The systematic review of the cartography and stratigraphic record of the Rio das Velhas greenstone belt, through the combination of geological mapping and petrography, allied with compiled whole-rock geochemical and geochronological data suggest that:

(i) The stratigraphic sequence of the RVGB is better approached if subdivided into three distinct tectonostratigraphic blocks, i.e., Santa Bárbara (SB), Nova Lima-Caeté (NLC) and São Bartolomeu (SBT). The subdivision follows major stratigraphic and tectonic discontinuities in the RVGB and 
each domain led to the recognition and individualization of formal stratigraphic units (formations), with their respective stratigraphic columns.

(ii) The SB block contains a rock sequence made up of basal metakomatiites (Quebra Osso Group), followed by tholeiitic metabasalts and clasto-chemical metasedimentary rocks of the Nova Lima Group (Vigário da Vara, Santa Quitéria and Córrego do Sítio formations) and metasedimentary rocks of the Maquiné Group (Palmital and Casa Forte formations).

(iii) The NLC block is the only with a complete greenstone belt sequence, consisting of basal tholeiitic-komatiitic metabasalts of the Ouro Fino and Morro Vermelho formations, followed by acid and intermediate metavolcanic and metavolcaniclastic rocks (Mestre Caetano Formation), and a metasedimentary sequence with a significant volcanogenic contribution (Ribeirão do Brumado Formation), all belonging to the Nova Lima Group. The top siliciclastic rocks of the Maquiné Group (Palmital and Casa Forte formations) complete the sequence.

(iv) The SBT block contains only the metasedimentary rocks that mark the top of the Nova Lima Group (Fazenda Velha, Córrego da Paina and Pau D'Óleo formations), and a distinct unit of the Maquiné Group (Andaimes Formation).

(v) The subdivision of the RVGB into three blocks that differ in geological processes, depositional environments, and stratigraphic sequences open wide horizons for the investigation of the individual structural framework and devise additional or alternative mineral exploration projects adequate for each block.

(vi) Volcanic architecture and depositional models for the RVGB rock protoliths can be summarized, as follows:

- Extrusion of Quebra Osso komatiite lavas along fissures onto the Santa Bárbara Complex, in a submarine environment, with localized clasto-chemical sedimentation;

- Subaqueous ultrabasic/basic volcanism, representing the lower portion of Nova Lima Group in the NLC and SB blocks. Minor chemical and clastic metasedimentary rocks occur interbedded with the volcanic sequence;

- Exclusive explosive acid to intermediate volcanism of the Nova Lima Group in the NLC block, represented by volcaniclastic and volcanogenic sediments;

- Clasto-chemical sedimentation, characterized by the intercalation of thick layers of BIF and clastic metasedimentary rocks in the SB block;

- Deposition of thick packages of clastic sediments by turbidity currents and debris flows. Distinct sources may be present, including acid and basic rocks of the greenstone belt sequence and granite-gneissic rocks of the TTG basement;

- The deposition of the Maquiné basin on top of the sequence, in shallow marine, coastal and alluvial-fluvial environments. The greenstone belt itself and the exhumed TTG basement were the source of these sediments.

\section{Acknowledgments}

We acknowledge the support provided by the geology team of Geological Survey of Brazil, especially Nicola Signorelli, Manoel Tuller, José Heleno Ribeiro, Wilson Féboli, Sérgio Silva, Orivaldo Baltazar, José Adilson Cavalcanti, and Claiton Piva. We are grateful to Suzan Moura and Guilherme Benedito for the support on the petrographic descriptions. We appreciate the supervision of Marcelo Marinho and the colleagues Camila Basto, Márcio Silva, and Paulo Amorim, whose comments and suggestions improved an earlier version of the manuscript. We sincerely appreciate the Journal's anonymous reviewers for their valuable comments, advice, and contributions to improve the original version of the manuscript.

\section{References}

Acken D.V., Hoffmann J.E., Schorscher J.H.D., Schulz T., Heuser A., Lugueta A. 2016. Formation of high-Al komatiites from the Mesoarchean Quebra Osso Group, Minas Gerais, Brazil: Trace elements, HSE systematics and Os isotopic signature. Chemical Geology, 422, 108-121. https://doi.org/10.1016/j.chemgeo.2015.12.015

Alkmim F.F., Marshak S. 1998. Trans-Amazonian orogeny in the southern São Francisco craton region, Minas Gerais, Brazil: evidence for Paleoproterozoic collision and collapse in the Quadrilátero Ferrífero. Precambrian Research, 90 (1-2), 29-58. https://doi.org/10.1016/ S0301-9268(98)00032-1

Alkmim F.F., Teixeira W. 2017. The Paleoproterozoic Mineiro Belt and the Quadrilátero Ferrífero. In: Heilbron M., Cordani U., Alkmim F. (eds) São Francisco Craton, Eastern Brazil. Regional Geology Reviews. Springer, p. 71-94. https://doi.org/10.1007/978-3-319-01715-0 5

Allen J.R.L. 1963. The classification of cross-stratified units with notes on their origin. Sedimentology, 2(2), 93-114. https://doi. org/10.1111/j.1365-3091.1963.tb01204.x

Allen J.R.L. 1968. Current Ripples: their Relation to Patterns of Water and Sediment Motion. North-Holland Publishing Company, Amsterdam, 443 p. http://dx.doi.org/10.1017/S001675680005946X

Almeida F.F.M. 1976. Estruturas do Pré-Cambriano inferior brasileiro. In: Congresso Brasileiro de Geologia, 29, 201-202.

Angeli G. 2016. Arcabouço estrutural e contribuição à estratigrafia do Grupo Maquiné, Quadrilátero Ferrífero, Minas Gerais. MSc. Dissertation, Departamento de Geologia da Universidade Federal de Ouro Preto, Ouro Preto, 102 p. Available on line at: http://www. repositorio.ufop.br/handle/123456789/6402 (accessed on 16 September 2020)

Anhaeusser C.R. 2014. Archaean greenstone belts and associated granitic rocks-a review. Journal of African Earth Sciences, 100, 684732. https://doi.org/10.1016/j.jafrearsci.2014.07.019

Araújo J.C.S, Ribeiro J.H., Tuller M.P, Signorelli N. 2020a. Carta geológica e de recursos minerais: Folha Caeté - SE.23-Z-C-VI-4-NO. Escala 1:25.000. Belo Horizonte, CPRM. Available on line at: http://rigeo. cprm.gov.br/handle/doc/20500 (accessed on 16 September 2020)

Araújo J.C.S, Ribeiro J.H., Tuller M.P, Signorelli N. 2020b. Carta geológica e de recursos minerais: Folha Gandarela - SE.23-X -A-III-2-NO. Escala 1:25.000. Belo Horizonte, CPRM. Available on line at: http://rigeo.cprm. gov.br/handle/doc/20502 (accessed on 16 September 2020)

Araújo J.C.S, Ribeiro J.H., Tuller M.P, Signorelli N. 2020c. Carta geológica e de recursos minerais: Folha Gongo Soco - SE.23-Z -C-VI-4-NO. Escala 1:25.000. Belo Horizonte, CPRM. Available on line at: http:// rigeo.cprm.gov.br/handle/doc/20499 (accessed on 16 September 2020)

Araújo J.C.S, Ribeiro J.H., Tuller M.P, Signorelli N. 2020d. Carta geológica e de recursos minerais: Folha Serra da Piedade - SE.23Z-C-VI-4-NO. Escala 1:25.000. Belo Horizonte, CPRM. Available on line at: http://rigeo.cprm.gov.br/handle/doc/20491 (accessed on 16 September 2020)

Araújo J.C.S. 2018. Modelo deposicional das formações ferríferas bandadas hospedeiras de ouro no greenstone belt arqueano Rio das Velhas, Quadrilátero Ferrífero, com base em geoquímica e análises in situ de magnetita por ablação a laser via ICP-MS. MSc. Dissertation, Universidade Federal de Minas Gerais, Belo Horizonte, 167 p. Available on line at: http://rigeo.cprm.gov.br/jspui/handle/doc/20679 (accessed on 16 September 2020)

Araújo J.C.S., Lobato M.L. 2019. Depositional model for banded iron formation host to gold in the Archean Rio das Velhas greenstone belt, Brazil, based on geochemistry and LA-ICP-MS magnetite analyses. Journal of South American Earth Sciences, 94, 102205. https://doi. org/10.1016/j.jsames.2019.05.021

Araújo J.C.S., Magalhães J.R. 2017. Petrografia, Litogeoquímica e Geocronologia dos Supergrupos Rio das Velhas e Minas na Porção Noroeste do Sinclinal Gandarela, Quadrilátero Ferrífero, Brasil. In: Simpósio de Geologia do Sudeste, 15, Diamantina.

Babinski M., Chemale F., Van Schmus W.R. 1995. The Pb/Pb age of the Minas Supergroup carbonate rocks, Quadrilátero Ferrífero, Brazil. Precambrian Research, 72(3-4), 235-245. https://doi. org/10.1016/0301-9268(94)00091-5 
Baltazar O.F., Baars F.J., Lobato L.M., Reis L.B., Achtschin A.B., Berni G.V., Silveira V.D. 2005a. Mapa Geológico Caeté na Escala 1:50.000 com Nota Explicativa. In: Lobato L.M. (ed.). Projeto Geologia do Quadrilátero Ferrífero: Integração e Correção Cartográfica em SIG com nota explicativa. Belo Horizonte, CODEMIG.

Baltazar O.F., Baars F.J., Lobato L.M., Reis L.B., Achtschin A.B., Berni G.V., Silveira V.D. 2005b. Mapa Geológico Belo Horizonte na Escala 1:50.000 com Nota Explicativa. In: Lobato L.M. (ed.). Projeto Geologia do Quadrilátero Ferrífero: Integração e Correção Cartográfica em SIG com nota explicativa. Belo Horizonte, CODEMIG.

Baltazar O.F., Pedreira A.J. 2000. Associações Litofaciológicas. In: Zucchetti M., Baltazar O.F. (ed.). Projeto Rio das Velhas: Texto explicativo do mapa geológico integrado. Escala 1:100.000. 2nd reprint. Belo Horizonte, DNPM, CPRM. p. 42-46.

Baltazar O.F., Raposo F.O. 1993. Mariana: folha SF.23-X-B-I: Estado de Minas Gerais: texto explicativo. Brasília, DNPM, CPRM. 183 p. Available on line at: http://rigeo.cprm.gov.br/jspui/handle/doc/8634 (accessed on 16 September 2020)

Baltazar O.F., Silva S.L. 1996. Projeto Rio das Velhas: Mapa Geológico Integrado do Supergrupo Rio das Velhas. Escala 1:100.000. Belo Horizonte, DNPM, CPRM.

Baltazar O.F., Zucchetti M. 2007. Lithofacies associations and structural evolution of the Archean Rio das Velhas greenstone belt, Quadrilátero Ferrifero, Brazil: A review of the setting of gold deposits. Ore Geology Reviews, 32(3-4), 471-499. https://doi.org/10.1016/j. oregeorev.2005.03.021

Barbosa A.L.M. 1968. Contribuições recentes à geologia do Quadrilátero Ferrífero. Ouro Preto, Escola de Minas da Universidade Federal de Ouro Preto, $68 \mathrm{p}$

Belo de Oliveira O.A. 1986. As falhas de empurrão e suas implicações na estratigrafia e metalogênese do Quadrilátero Ferrífero. In: Congresso Brasileiro de Geologia, 34, 5-15.

Bouma A.H. 1962. Sedimentology of some Flysch deposits: A graphic approach to facies interpretation. Elsevier, Amsterdam, $168 \mathrm{p}$ Available on line at: https://lib.ugent.be/catalog/rug 01:000978747 (accessed on 16 September 2020)

Cabral A.R., Zeh A., Koglin N., Gomes Jr. A.A.S., Viana D.J., Lehmann B. 2012. Dating the Itabira iron formation, Quadrilátero Ferrifero of Minas Gerais, Brazil, at $2.65 \mathrm{Ga}$ : Depositional U-Pb age of zircon from a metavolcanic layer. Precambrian Research, 204-205, 40-45. https:// doi.org/10.1016/j.precamres.2012.02.006

Cavalcanti J.A.D. 2018. Estratigrafia das folhas: Belo Horizonte, São Sebastião das Águas Claras, Santa Luzia, Nova Lima e Rio Acima. In: Araújo J.C.S., Cavalcanti J.A.D., Ferreira R.C.R., Freitas F.M. Relatório Técnico Anual 2018: ARIM - Evolução Crustal e Metalogênese do Quadrilátero Ferrífero: relatório interno. CPRM.

Cavalcanti J.A.D., Ribeiro J.H., Tuller M.P, Signorelli N. 2020a. Carta geológica e de recursos minerais: Folha Belo Horizonte - SF.23-ZC-VI-3-SO. Escala 1:25.000. Belo Horizonte, CPRM. Available on line at: http://rigeo.cprm.gov.br/handle/doc/20508 (accessed on 16 September 2020)

Cavalcanti J.A.D., Ribeiro J.H., Tuller M.P, Signorelli N. 2020b. Carta geológica e de recursos minerais: Folha Nova Lima - SF.23-Z-C-VI-3SE. Escala 1:25.000. Belo Horizonte, CPRM. Available on line at: $\underline{\text { http:// }}$ rigeo.cprm.gov.br/handle/doc/20506 (accessed on 16 September 2020)

Cavalcanti J.A.D., Ribeiro J.H., Tuller M.P, Signorelli N. 2020c. Carta geológica e de recursos minerais: Folha Rio Acima - SF.23-X-AIII-1-NE. Escala 1:25.000. Belo Horizonte, CPRM. Available on line at: http://rigeo.cprm.gov.br/handle/doc/20497 (accessed on 16 September 2020)

Cavalcanti J.A.D., Ribeiro J.H., Tuller M.P, Signorelli N. 2020d. Carta geológica e de recursos minerais: Folha Santa Luzia - SF.23-ZC-VI-3-NE. Escala 1:25.000. Belo Horizonte, CPRM. Available on line at: http://rigeo.cprm.gov.br/handle/doc/20494 (accessed on 16 September 2020)

Cavalcanti J.A.D., Ribeiro J.H., Tuller M.P, Signorelli N. 2020e. Carta geológica e de recursos minerais: Folha São Sebastião das Águas Claras - SF.23-X-A-III-1-NO. Escala 1:25.000. Belo Horizonte, CPRM. Available on line at: http://rigeo.cprm.gov.br/handle/doc/20492 (accessed on 16 September 2020)

Chemale F., Rosière C.A., Endo I. 1994. The tectonic evolution of the Quadrilátero Ferrífero, Minas Gerais, Brazil. Precambrian Research, 65, 25-54. https://doi.org/10.1016/0301-9268(94)90098-1

Coelho V.V. 2015. Modelagem metamórfica e geocronologia de xistos e anfibolitos do grupo Nova Lima, Supergrupo Rio das Velhas,
Quadrilátero Ferrífero. MSc Dissertation, Universidade Federal de Ouro Preto, Ouro Preto, 183 p. Available on line at: http://www. repositorio.ufop.br/handle/123456789/6377 (accessed on 16 September 2020)

Costa C.S. 1995. Petrogênese do corpo metaultramáfico do Córrego dos Boiadeiros, Quadrilátero Ferrífero, Minas Gerais, Brasil. MSc Dissertation, Instituto de Geociências, Universidade Federal de Minas Gerais, Belo Horizonte, $172 \mathrm{p}$.

Costa C.S., Costa A.G., Rosière C.A. 1992. Considerações preliminares sobre a ambiência magmática das rochas do Complexo Córrego dos Boiadeiros, Quadrilátero Ferrífero, MG. In: Congresso Brasileiro de Geologia, 37, 455-456.

Costa J.L.G. 1994. Carta geológica Folha Nova Lima/Santa Luzia: SE.23Z-C-VI-3-SE / SE.23-Z-C-VI-3-NE. In: CPRM. Projeto Rio das Velhas: Folhas Belo Horizonte e São Sebastião das Águas Claras, Nova Lima e Santa Luzia, Serra da Piedade, Gongo Soco, Rio Acima, Caeté, Gandarela: texto: vol. I. Escala 1:25:000. Belo Horizonte, DNPM, CPRM. Available on line at: http://rigeo.cprm.gov.br/jspui/handle/ doc/8732 (accessed on 16 September 2020)

CPRM. 1994. Projeto Rio das Velhas: Folhas Belo Horizonte e São Sebastião das Águas Claras, Nova Lima e Santa Luzia, Serra da Piedade, Gongo Soco, Rio Acima, Caeté, Gandarela: texto: vol. I. Escala 1:25:000. Belo Horizonte, DNPM, CPRM. Available on line at: http://rigeo.cprm.gov.br/jspui/handle/doc/8732 (accessed on 16 September 2020)

CPRM. 1996. Projeto Rio das Velhas: mapeamento geológico: escala 1:25.000: sinopses geológicas. Programa Estudos de Distritos Mineiros. Belo Horizonte, DNPM, CPRM. Available on line at: http://rigeo.cprm. gov.br/jspui/handle/doc/9975 (accessed on 16 September 2020)

Cutts K., Lana C., Alkmim F.F., Farina F., Moreira H., Coelho V. 2019. Metamorphism and exhumation of basement gneiss domes in the Quadrilátero Ferrífero: Two stage dome-and-keel evolution? Geoscience Frontiers, 10(5), 1765-1787. https://doi.org/10.1016/j. gsf.2019.02.009

Dopico C.I.M., Lana C., Moreira H.S., Cassino L.F., Alkmim F.F. 2017. U-Pb ages and $\mathrm{Hf}$-isotope data of detrital zircons from the late NeoarcheanPaleoproterozoic Minas Basin, SE Brazil. Precambrian Research, 291, 143-161. http://dx.doi.org/10.1016/i.precamres.2017.01.026

Dorr II J.V.N. 1969. Physiographic, Stratigraphic and Structural Development of the Quadrilatero Ferrífero, Minas Gerais, Brazil. Geological Survey Professional Paper, 641-A. Washington D.C., U.S. Government Printing Office, 110. Available on line at: https://pubs. usgs.gov/pp/0641a/report.pdf (accessed on 16 September 2020). https://doi.org/10.3133/pp641A

Dorr II J.V.N., Gair J.E., Pomerene, J.B., Rynearson, G.A. 1957. Revisão da estratigrafia pré-cambriana do Quadrilátero Ferrífero, Brasil. Rio de Janeiro, DNPM, $31 \mathrm{p}$.

Drake A.A., Morgan B.A. 1980. Precambrian Plate Tectonics in the Brazilian Shield: Evidence from the Pre-Minas Rocks of the Quadrilátero Ferrífero, Minas Gerais. United States Geological Survey Professional Paper. 1119-B, 19 p. Available online at: https://pubs. usgs.gov/pp/1119a-b/report.pdf

Duque T.R.F. 2018. O grupo Itacolomi em sua área tipo: estratigrafia, estrutura e significado tectônico. MSc Dissertation, Universidade Federal de Ouro Preto, Ouro Preto, 102 p. Available on line at: http:// www.repositorio.ufop.br/handle/123456789/10823 (accessed on 16 September 2020)

Dutra L.F., Martins M., Lana C. 2019. Sedimentary and U-Pb detrital zircons provenance of the Paleoproterozoic Piracicaba and Sabará groups, Quadrilátero Ferrífero, Southern São Francisco craton, Brazil. Brazilian Journal of Geology, 49(2). https://doi.org/10.1590/2317$\underline{4889201920180095}$

Farina F., Albert C., Lana C. 2015. The Neoarchean transition between medium-and high-K granitoids: Clues from the Southern São Francisco Craton (Brazil). Precambrian Research, 266, 375-394. https://doi.org/10.1016/i.precamres.2015.05.038

Féboli W.L., Signorelli N. 1996. Sinopse Geológica da Folha Itabirito. In: CPRM. Projeto Rio das Velhas: mapeamento geológico: escala 1:25.000: sinopses geológicas. Programa Estudos de Distritos Mineiros. Belo Horizonte, DNPM, CPRM. p. 34-43. Available on line at: http://rigeo.cprm.gov.br/jspui/handle/doc/9975 (accessed on 16 September 2020)

Fernandes V.M.T. 2016. Petrogênese e Geoquímica de Rochas Metaultramáficas e Metamáficas do Corpo Córrego dos Boiadeiros, Grupo Nova Lima, Quadrilátero Ferrífero, MG. MSc. Dissertation, 
Departamento de Geologia, Universidade Federal de Ouro Preto, Ouro Preto, 96 p. Available on line at: http://www.repositorio.ufop.br/ handle/123456789/7082 (accessed on 16 September 2020)

Ferreira R.C.R., Pinheiro M.A.P., Magalhães J.R., Novo T.A., Schorscher J.H.D., Queiroga G. 2020e. Physical volcanology and petrogenesis of the Archean Quebra Osso komatiite flow field, Rio das Velhas greenstone belt, Quadrilátero Ferrífero (Brazil). Lithos, 370-371, 105626. https://doi.org/10.1016/j.lithos.2020.105626

Ferreira R.C.R., Ribeiro J.H., Tuller M.P, Signorelli N. 2020a. Carta geológica e de recursos minerais: Folha Catas Altas - SF.23-XB-I-1-NO. Escala 1:25.000. Belo Horizonte, CPRM. Available on line at: http://rigeo.cprm.gov.br/handle/doc/20503 (accessed on 16 September 2020)

Ferreira R.C.R., Ribeiro J.H., Tuller M.P, Signorelli N. 2020b. Carta geológica e de recursos minerais: Folha Conceição do Rio Acima - SF.23-X-A-III-2-NE. Escala 1:25.000. Belo Horizonte, CPRM. Available on line at: http://rigeo.cprm.gov.br/handle/doc/20505 (accessed on 16 September 2020)

Ferreira R.C.R., Ribeiro J.H., Tuller M.P, Signorelli N. 2020c. Carta geológica e de recursos minerais: Folha Santa Bárbara - SE.23-ZD-IV-3-SO. Escala 1:25.000. Belo Horizonte, CPRM. Available on line at: http://rigeo.cprm.gov.br/handle/doc/20496 (accessed on 16 September 2020)

Ferreira R.C.R., Ribeiro J.H., Tuller M.P, Signorelli N. 2020d. Carta geológica e de recursos minerais: Folha Santa Rita Durão - SF.23X-B-I-1-SO. Escala 1:25.000. Belo Horizonte, CPRM. Available on line at: http://rigeo.cprm.gov.br/handle/doc/20493 (accessed on 16 September 2020)

Freitas F.M, Dias P.H.A., Signorelli N., Tuller M.P., Ribeiro J.H. 2020a. Carta geológica e de recursos minerais: Folha Capanema - SF.23X-A-III-2-SE. Escala 1:25.000. Belo Horizonte, CPRM. Available on line at: http://rigeo.cprm.gov.br/handle/doc/20501 (accessed on 16 September 2020)

Freitas F.M, Dias P.H.A., Signorelli N., Tuller M.P., Ribeiro J.H. 2020 b. Carta geológica e de recursos minerais: Folha Itabirito - SF.23-XA-III-1-SE. Escala 1:25.000. Belo Horizonte, CPRM. Available on line at: http://rigeo.cprm.gov.br/handle/doc/20504 (accessed on 16 September 2020)

Freitas F.M, Dias P.H.A., Signorelli N., Tuller M.P., Ribeiro J.H. 2020c. Projeto Evolução Crustal e Metalogenética do Quadrilátero Ferrífero, Folha Rio de Pedras - SF.23-X-A-III-2-SO. Escala 1:25.000. Belo Horizonte, CPRM. Available on line at: http://rigeo.cprm.gov.br/handle/ doc/20495 (accessed on 16 September 2020)

Freitas F.M, Pinheiro M.A.P., Novo T.A., Magalhães J.R., Marinho M.S. 2019. U-Pb ages for metasedimentary rocks of the Catarina Mendes Formation, Quadrilátero Ferrífero. In: Simpósio sobre o Cráton do São Francisco e Orógenos Marginais, 4, 34.

Freitas F.M. 2019. Geocronologia em U-PB em zircões detríticos e caracterização litoestratigráfica das rochas metassedimentares da unidade Catarina Mendes: implicações quanto à evolução geotectônica do Quadrilátero Ferrífero. MSc Dissertation, Instituto de Geociências, Universidade Federal de Minas Gerais, Belo Horizonte, 83 p. Available on line at: http://rigeo.cprm.gov.br/handle/doc/21302 (accessed on 16 September 2020)

Gair J.E. 1962. Geology and Ore Deposit of the Nova Lima and Rio Acima Quadrangles, Minas Gerais, Brazil. United States Geological Survey Professional Paper 341-A, 67 p. Available on line at: http://pubs. er.usgs.gov/publication/pp341A (accessed on 16 September 2020)

Golia A. 1997. Petrografia e geoquímica dos metassedimentos do Grupo Nova Lima, greenstone belt Rio das Velhas na região de São Bartolomeu: modelagem de área-fonte, proveniência e ambiente tectônico. MSc Dissertation, Departamento de Geologia da Escola de Minas, Universidade Federal de Ouro Preto, Ouro Preto, 142 p.

Groves D.I., Barley M.E. 1994. Archean mineralization. In: Condie K.C. (ed.). Archean Crustal Evolution. Amsterdam, Elsevier. p. 461-503.

Guerrero L.J.R. 2016. Metalogênese do depósito aurífero Pilar, Santa Bárbara, MG. MSc Dissertation, Instituto de Ciências Exatas, Universidade Federal do Amazonas, Manaus. 115 p. Available on line at: https://tede.ufam.edu.br/handle/tede/5570 (accessed on 16 September 2020)

Harder E.C., Chamberlin R.T. 1915. The geology of central Minas Geraes, Brazil. The Journal of Geology, 23(5), 341-378. https://doi. org/10.1086/622256

Hartmann A., Endo I., Suita M.T.F., Santos J.O.S., Frantz C.J., Carneiro M.A., McNaughton N.J., Barley M.E. 2006. Provenance and age delimitation of Quadrilátero Ferrífero sandstones based on zircon U$\mathrm{Pb}$ isotopes. The Journal of South American Earth Sciences, 20, 273285. https://doi.org/10.1016/j.jsames.2005.07.015

Herrington R., Evans D.M., Buchanan D.L. 1997. Greenstone Belts: rock components, sources, provenances, and structures - Metallogenic aspects. In: De Witt M.J., Ashwall L.D. (eds.). Greenstone Belt. Oxford University Press, Oxford. p. 176-219.

Junqueira P.A., Lobato L.M., Ladeira E.A., Simões E.J.M. 2007. Structural control and hydrothermal alteration at the BIF-hosted Raposos lodegold deposit, Quadrilátero Ferrífero, Brazil. Ore Geology Reviews, 32(3-4), 629-650. https://doi.org/10.1016/j.oregeorev.2006.03.004

Koglin N., Zeh A., Cabral A.R., Gomes A.A.S., Neto A.V.C., Brunetto W.J., Galbiatti H. 2014. Depositional age and sediment source of the auriferous Moeda Formation, Quadrilátero Ferrífero of Minas Gerais, Brazil: New constraints from $\mathrm{U}-\mathrm{Pb}-\mathrm{Hf}$ isotopes in zircon and xenotime. Precambrian Research, 255(1), 96-108. https://doi. org/10.1016/j.precamres.2014.09.010

Ladeira E.A. 1980. Metallogenesis of Gold at the Morro Velho Mine and in the Nova Lima District, Quadrilátero Ferrífero, Minas Gerais, Brazil. PhD Thesis, Department of Geology, University of Western Ontario, Canada, $271 \mathrm{p}$.

Ladeira E.A. 1985. Metalogênese do ouro na mina de Morro Velho e no distrito de Nova Lima, Quadrilátero Ferrífero, Minas Gerais, Brasil. In: Grossi Sad, J.H., da Silva, B. (eds). Contribuição à geologia e à petrologia. Belo Horizonte, Companhia Brasileira Mineração e Metalurgia/Sociedade Brasileira de Geologia. p. 95-151.

Lana C. Alkmim F.F., Armstrong R., Scholz R., Romano R., Nalini Jr. H.A. 2013. The ancestry and magmatic evolution of Archean TTG rocks of the Quadrilátero Ferrífero province, southeast Brazil. Precambrian Research 231, 157-173. https://doi.org/10.1016/j. precamres.2013.03.008

Lima L.C. 2012. Geologia do depósito LODE Au-As-Sb Laranjeiras, em metaturbitos do Grupo Nova Lima, Quadrilátero Ferrífero, Minas Gerais. MSc Dissertation, Instituto de Geociências, Universidade Federal de Minas Gerais, Belo Horizonte, 306 p. Available on line at: http://hdl.handle.net/1843/MPBB-8YXGJH (accessed on 16 September 2020)

Lobato L.M., Ribeiro-Rodrigues L.C., Vieira F.W.R. 2001b. Brazil's premier gold province. Part II: geology and genesis of gold deposits in the Archean Rio das Velhas greenstone belt, Quadrilátero Ferrífero. Mineralium Deposita, 36, 249-277. https://doi.org/10.1007/ s001260100180

Lobato L.M., Ribeiro-Rodrigues L.C., Zucchetti M., Noce C.M., Baltazar O.F., Silva L.C., Pinto C.P. 2001a. Brazil's premier gold province. Part I: The tectonic, magmatic, and structural setting of the Archean Rio das Velhas greenstone belt, Quadrilátero Ferrífero. Mineralium Deposita, 36, 228-248. http://dx.doi.org/10.1007/s001260100179

Lobato L.M., Santos J.O.S., McNaughton N.J., Fletcher I.R., Noce C.M., 2007. U-Pb SHRIMP monazite ages of the giant Morro Velho and Cuiabá gold deposits, Rio das Velhas greenstone belt, Quadrilátero Ferrífero, Minas Gerais, Brazil. Ore Geology Reviews, 32(3-4), 674680. http://dx.doi.org/10.1016/j.oregeorev.2006.11.007

Loczy L., Ladeira E.A. 1976. Geologia Estrutural e Introdução à Geotectônica. São Paulo, Edgar Blücher, 528 p.

Lowe D.R. 1980. Archean sedimentation. Annual Review of Earth and Planetary Sciences, 8, 145-167. http://dx.doi.org/10.1146/annurev. ea.08.050180.001045

Machado N., Carneiro M.A. 1992. U-Pb evidence of late Archean tectonothermal activity in the southern São Francisco shield, Brazil. Canadian Journal of Earth Science, 29, 2341-2346. http://dx.doi.org/10.1139/e92-182

Machado N., Noce C., Ladeira E., Belo de Oliveira O. 1992. U-Pb geochronology of Archean magmatism and Proteozoic metamorphism in the Quadrilatero Ferrifero, southern São Francisco craton, Brazil. GSA Bulletin, 104(9), 721-727. https://doi.org/10.1130/00167606(1992)104<1221:UPGOAM>2.3.CO;2

Machado N., Noce C.M., Belo de Oliveira O.A, Ladeira E.A. 1989 Evolução Geológica do Quadrilátero Ferrífero no Arqueano e Proterozóico Inferior, com base em geocronologia U-Pb. In: Simpósio de Geologia de Minas Gerais, 5, 1-5.

Machado N., Schrank A., Noce C.M., Gauthier G. 1996. Ages of detrital zircon from Archean-Paleoproterozoic sequences: implications for greenstone belt setting and evolution of a Transamazonian foreland basin in Quadrilátero Ferrífero, southeast Brazil. Earth and Planetary Science Letters 141(1-4), 259-276. https://doi.org/10.1016/0012$\underline{821 \times(96) 00054-4}$ 
Malouf R.F., Corrêa Neto A.V. 1996. Sinopse Geológica da Folha Conceição do Rio Acima. In: CPRM. Projeto Rio das Velhas: mapeamento geológico: escala 1:25.000: sinopses geológicas. Programa Estudos de Distritos Mineiros. Belo Horizonte, DNPM, CPRM. p. 17-23. Available on line at: http://rigeo.cprm.gov.br/jspui/ handle/doc/9975 (accessed on 16 September 2020)

Marshak S., Tinkham D., Alkmim F.F., Brueckner H., Bornhorst T. 1997. Dome-and-keel provinces formed during Paleoproterozoic orogenic collapse-Core complexes, diapirs, or neither? Examples from the Quadrilátero Ferrífero and the Penokean orogen. Geology, 25(5), 415418. https://doi.org/10.1130/0091-7613(1997)025<0415:DAKPFD>2.3. $\mathrm{CO} ; 2$

Martins B.S., Lobato L.M., Rosière C.A., Hagemann S.G., Santos J.O.S. Villanova F.L., Figueiredo e Silva R.C., Lemos L.H. 2016. The Archean BIF-hosted Lamego gold deposit, Rio das velhas greenstone belt, Quadrilátero Ferrífero: evidence for Cambrian structural modification of an Archean orogenic gold deposit. Ore Geology Reviews. 72(1), 963-988. https://doi.org/10.1016/j.oregeorev.2015.08.025

Martins Pereira S.L, Lobato L.M., Ferreira J.E., Jardim E.C. 2007. Nature and origin of the BIF hosted São Bento gold deposit, Quadrilátero Ferrifero, Brazil, with special emphasis on structural controls. Ore Geology Reviews 32(3-4), 571-595. https://doi.org/10.1016/j. oregeorev.2005.03.018

Maxwell C.H. 1972. Geology and Ore Deposits of the Alegria District, Minas Gerais, Brazil. United States Geological Survey Professional Paper, v. 341-J. 72 p. https://doi.org/10.3133/pp341J

McLennan S.M. 1984. Petrological characteristics of Archean graywackes. SEPM Journal of Sedimentary Research 54(3), 889-898. http://dx.doi. org/10.1306/212F852B-2B24-11D7-8648000102C1865D

McPhie J., Doyle M., Allen R. 1993. Volcanic Textures: a guide to the interpretation of textures in volcanic rocks. Tasmania, Tasmanian Government Printing Office, 196 p. https://doi.org/10.1007/ BF00326466

Moreira H., Lana C., Naline Jr. H.A. 2016. The detrital zircon record of an Archaean convergent basin in the Southern São Francisco Craton, Brazil. Precambrian Research, 275, 84-99. http://dx.doi.org/10.1016/j. precamres.2015.12.015

Noce C.M., Machado N., Teixeira W. 1998. U-Pb geochronology of gneisses and granitoids in the Quadrilátero Ferrifero (southern São Francisco craton): age constraints for Archean and Paleoproterozoic magmatism and metamorphism. Revista Brasileira de Geociências, 28, 95-102. http://dx.doi.org/10.25249/0375-7536.199895102

Noce C.M., Zuccheti M., Baltazar O.F., Armstrong R., Dantas E., Renger F.E., Lobato L.M. 2005. Age of felsic volcanism and the role of ancient continental crust in the evolution of the Neoarchean Rio das Velhas Greenstone belt (Quadrilátero Ferrífero, Brazil): U-Pb zircon dating of volcaniclastic graywackes. Precambrian Research, 141(1-2), 67-82. https://doi.org/10.1016/j.precamres.2005.08.002

Nunes F.S. 2016. Contribuição à estratigrafia e geocronologia U-Pb de zircões detríticos da Formação Moeda (Grupo Caraça, Supergrupo Minas) na Serra do Caraça, Quadrilátero Ferrífero, Minas Gerais. MSc Dissertation, Departamento de Geologia, Universidade Federal de Ouro Preto, Ouro Preto, 79 p. Available on line at: http:// www.repositorio.ufop.br/handle/123456789/7134 (accessed on 16 September 2020)

O'Rourke J.E. 1957. The stratigraphy of metamorphic rocks of the Rio de Pedras and Gandarela quadrangles, Minas Gerais, Brazil. PhD thesis, University of Winscosin, Winscosin, $106 \mathrm{p}$.

Padgham W.A., Fyson W.K. 1992. The Slave Province: a distinct Archean craton. Canadian Journal of Earth Sciences, 29(10), 2072-2086. https://doi.org/10.1139/e92-165

Padilha A.V. 1984. Formação Córrego dos Boiadeiros - uma sequência komatítica na base do Grupo Nova Lima, Supergrupo Rio das Velhas, Quadrilátero Ferrífero, Minas Gerais. In: Congresso Brasileiro de Geologia, 33, 146-147.

Pedreira A. J. 1998. Associações de litofácies do Supergrupo Rio das Velhas: Relatório interno. CPRM.

Pedreira A.J. 1995. Observações sobre a sedimentologia do "Greenstone Belt" Rio das Velhas: Relatório interno. CPRM.

Pedreira A.J., Silva S.L. 1996. Sistemas deposicionais do greenstone belt Rio das Velhas, Quadrilátero Ferrífero, Minas Gerais. In: Congresso Brasileiro de Geologia, 39, 138-140.

Pinheiro M.A.P, Cavalcanti J.A.D. 2018. Petrografia de rochas da Suíte Córrego dos Boiadeiros. Relatório interno. CPRM.
Pinto C.P., Silva L.C. 1996. Contrasting tectono-stratigraphic domains in the Rio das Velhas Greenstone Belt (RVGB), MG, Brazil. In: Symposium Archaean Terranes of the South American Platform, 2325.

Pinto C.P., Silva M.A. 2014. Mapa Geológico do Estado de Minas Gerais. Escala 1:1.000.000. Belo Horizonte, CODEMIG, CPRM. Available on line at: http://rigeo.cprm.gov.br/jspui/handle/doc/20786 (accessed on 16 September 2020)

Porto C.G. 2008. A mineralização aurífera do depósito Córrego do Sítio e sua relação com o enxame de diques metamáficos no corpo Cachorro Bravo - Quadrilátero Ferrífero - MG. MSc Dissertation, Universidade Federal de Minas Gerais, Belo Horizonte, 117 p. Available on line at: http://hdl.handle.net/1843/IGCC-9B2GAK (accessed on 16 September 2020)

Ribeiro J.H., Tuller M.P. 1996. Sinopse Geológica da Folha São Bartolomeu. In: CPRM. Projeto Rio das Velhas: mapeamento geológico: escala 1:25.000: sinopses geológicas. Programa Estudos de Distritos Mineiros. Belo Horizonte, DNPM, CPRM. p. 84-94. Available on line at: http://rigeo.cprm.gov.br/jspui/handle/doc/9975 (accessed on 16 September 2020)

Ribeiro-Rodrigues L.C., Oliveira C.G. de, Friedrich G. 2007. The Archean BIF-hosted Cuiabá Gold deposit, Quadrilátero Ferrífero, Minas Gerais, Brazil. Ore Geology Reviews, 32(3-4), 543-570. https://doi. org/10.1016/j.oregeorev.2006.09.001

Romano R., Lana C., Alkmim F.F., Stevens G., Armstrong R. 2013. Stabilization of the southern portion of the São Francisco craton, SE Brazil, through a long-lived period of potassic magmatism. Precambrian Research, 224, 143-159. https://doi.org/10.1016/j. precamres.2012.09.002

Roncato J.G. 2016. Evolução de turbiditos e sua mineralização aurífera no lineamento Córrego do Sítio e área Cuiabá-Lamego, Supergrupo Rio das Velhas: geoquímica, geocronologia e in situ LA-ICP-MS em sulfetos. PhD Thesis, Instituto de Geociências, Universidade Federal de Minas Gerais, Belo Horizonte, 191 p. Available on line at: http://hdl. handle.net/1843/IGCC-ARNMM2 (accessed on 16 September 2020)

Roncato J.G., Lobato L.M., Lima L.C., Porto C.G., Figueiredo E, Silva R.C. 2015. Metaturbidite-hosted gold deposits, Córrego do Sítio Lineament, Quadrilátero Ferrifero, Brazil. Brazilian Journal of Geology, 45(1), 5-22. http://dx.doi.org/10.1590/23174889201500010001

Santos C.A. 2011. Geologia e petrogênese dos metakomatítos Arqueanos do Grupo Quebra Osso, Greenstone Belt Rio das Velhas, borda leste do Quadrilátero Ferrífero, MG. Graduation work, Instituto de Geociências, Universidade de São Paulo, São Paulo, 36 p.

Schorscher H.D. 1976. Polimetamorfismo do Pré-Cambriano na Região de Itabira, Minas Gerais. In: Congresso Brasileiro de Geologia, 29, 194-195.

Schorscher H.D. 1978. Komatítos na estrutura "Greenstone Belt" Série Rio das Velhas, Quadrilátero Ferrifero, Minas Gerais, Brasil. In: Congresso Brasileiro de Geologia, 30, 292-293.

Schorscher H.D. 1979. Evolução geotectônica e petrogenética do embasamento arqueano do Quadrilátero Ferrífero. Anais da Academia Brasileira de Ciências, 51, 766-768.

Schorscher H.D. 1992. Arcabouço petrográfico e evolução crustal de terrenos pré-cambrianos do sudeste de Minas Gerais. Quadrilátero Ferrífero, Espinhaço Meridional e domínios granito-gnáissicos adjacente. Habilitation Thesis, Instituto de Geociências, Universidade de São Paulo, São Paulo, 393 p. http://dx.doi.org/10.11606/T.44.2013. tde-11092013-114139

Schorscher J.H.D., Luchesi I., Queiroga, N.C.M., Abreu, G., Tamura R. M. 1990. Evolução pré-cambriana da região do Quebra Osso, Quadrilátero Ferrífero, MG. In: Congresso Brasileiro de Geologia, Resumos, 331-332.

Schrank A., Machado N. 1996. Idades U-Pb em monazitas e zircões das minas de Morro Velho e Passagem de Mariana- Quadrilátero Ferrífero (MG). In: Congresso Brasileiro de Geologia, 39, 470-472.

Schrank A., Padilha A.V., Sichel S., Szabo G.A.J. 1984. Komatiitos de Minas Gerais. In: Congresso Brasileiro de Geologia, 12, 5335-5377.

Schrank A., Souza Filho C.R., Roig H.L. 1990. Novas observações sobre as rochas ultramáficas do Grupo Quebra Osso e Formação Córrego dos Boiadeiros, "Greenstone belt" Rio das Velhas (MG). Cadernos IG/ UNICAMP, 1, 6-29.

Sepulveda G.O. 2020. Caracterização e geocronologia de sequências turbidíticas no leste do greenstone belt Rio das Velhas, Quadrilátero Ferrífero, Brasil. Msc Dissertation, Instituto de Geociências, Universidade Federal de Minas Gerais, Belo Horizonte, $79 \mathrm{p}$. 
Sichel S.E. 1983. Geologia das rochas pré-cambrianas da Região de Barão de Cocais e geoquímica preliminar dos komatítos do Supergrupo Rio das Velhas, Quadrilátero Ferrífero, MG. MSc Dissertation, Universidade Federal do Rio de Janeiro, Rio de Janeiro, $232 \mathrm{p}$.

Sichel S.E., Valença J.G. 1983. Geologia da região de Santa Bárbara, Quadrilátero Ferrífero, MG. In: Simpósio de Geologia de Minas Gerais, 2, 197-208.

Signorelli N., Féboli W.L., Silva J.N., Correa Neto A.V. 1996. Sinopse geológica da folha Rio de Pedras. In: CPRM. Projeto Rio das Velhas: mapeamento geológico: escala 1:25.000: sinopses geológicas. Programa Estudos de Distritos Mineiros. Belo Horizonte, DNPM, CPRM. p. 44-54. Available on line at: http://rigeo.cprm.gov.br/jspui/ handle/doc/9975 (accessed on 16 September 2020)

Silva C.M.G. 2006. Aplicação de isótopos radiogênicos na mineralização de ouro da mina Cuiabá, greenstone belt Rio das Velhas (MG). PhD Thesis, Instituto de Geociências, Universidade de São Paulo, São Paulo, 145 p. https://doi.org/10.11606/T.44.2006.tde-18112013$\underline{173953}$

Silva J.N., Féboli W.L., Signorelli N., Corrêa-Neto A.V. 1996. CPRM. Projeto Rio das Velhas: mapeamento geológico: escala 1:25.000: sinopses geológicas. Programa Estudos de Distritos Mineiros. Belo Horizonte, DNPM, CPRM. p. 55-62. Available on line at: http://rigeo. cprm.gov.br/jspui/handle/doc/9975 (accessed on 16 September 2020)

Silva L.C. 2000. Petrografia e Litogeoquímica. In: Zucchetti M., Baltazar O.F. (ed.). Projeto Rio das Velhas: Texto explicativo do mapa geológico integrado. Escala 1:100.000. 2nd reprint. Belo Horizonte, DNPM, CPRM. 52-100.

Silva L.C. 2000. Petrologia e litogeoquímica. In: Zucchetti M., Baltazar O.F. (ed.). Projeto Rio das Velhas: Texto explicativo do mapa geológico integrado. Escala 1:100.000. 2nd reprint. Belo Horizonte, DNPM, CPRM., 52-100.

Silva L.C., Zucchetti M., Silva S.L., Baltazar O.F., Malouf R.F., Silva J.N. 1995. Antofilita-cordierita xistos e paragêneses exóticas no Greenstone belt Rio das Velhas: possíveis origens e significados. A Terra em Revista, 35-45.

Silva L.C.F. 2007. Depósito Pilar: Contexto geológico, alteração hidrotermal e mineralização aurífera. MSc Dissertation, Instituto de Geociências, Universidade Federal de Minas Gerais, Belo Horizonte. 123 p. Available on line at: http://hdl.handle.net/1843/MPBB-7X4G9X (accessed on 16 September 2020)

Silva M.A., Cavalcanti, J.A.D., Araújo J.C.S., Ferreira R.C.R., Freitas F.M 2020. Mapa geológico e de recursos minerais: Quadrilátero Ferrífero - Subárea Central. Escala 1:75.000. Belo Horizonte, CPRM. Available on line at: http://rigeo.cprm.gov.br/handle/doc/20490 (accessed on 16 September 2020)

Silva S.L. 1994. Carta Geológica Folha Serra da Piedade SE.23-Z-CVI-4-NO. In: CPRM. Projeto Rio das Velhas: Folhas Belo Horizonte e São Sebastião das Águas Claras, Nova Lima e Santa Luzia, Serra da Piedade, Gongo Soco, Rio Acima, Caeté, Gandarela: texto: vol. I. Escala 1:25:000. Belo Horizonte, DNPM, CPRM. Available on line at: http://rigeo.cprm.gov.br/jspui/handle/doc/8732 (accessed on 16 September 2020)

Silva S.L. 1996. Sinopse Geológica da Folha Santa Bárbara. In: CPRM. Projeto Rio das Velhas: mapeamento geológico: escala 1:25.000: sinopses geológicas. Programa Estudos de Distritos Mineiros. Belo Horizonte, DNPM, CPRM. p. 11-16. Available on line at: http://rigeo. cprm.gov.br/ispui/handle/doc/9975 (accessed on 16 September 2020)

Silva S.L., Zucchetti M. 1993. Geologia do Supergrupo Rio das Velhas na folha Serra da Piedade (SE.23-Z-C-VI-4-NO). Belo Horizonte, DNPM, CPRM. 27 p.
Simmons G.C. 1968. Geology and mineral resources of the Barão de Cocais area, Minas Gerais, Brazil. United States Geological Survey Professional Paper, v. 341-H. 46 p.

Teixeira W., Ávila C.A., Dussin I.A., Corrêa Neto A.V., Bongiolo E.M., Santos J.O., Barbosa N.S. 2015. A juvenile accretion episode (2.35-2.32Ga) in the Mineiro belt and its role to the Minas accretionary orogeny: Zircon U-Pb-Hf and geochemical evidences. Precambrian Research, 256, 148-169. https://doi.org/10.1016/j.precamres.2014.11.009

Teixeira W., Oliveira E.P., Marques L.S. 2017. Nature and Evolution of the Archean Crust of the São Francisco Craton. In: Heilbron M., Cordani U., Alkmim F. (ed.). São Francisco Craton, Eastern Brazil. Regional Geology Reviews. Springer, p. 29-56. https://doi.org/10.1007/978-3319-01715-0 3

Tucker M.E. 1996. Sedimentary Rocks in the Field. 2nd edition. Chichester, John Wiley and Sons, 153 p. https://doi.org/10.1017/ S0016756800008037

Valladares F.B. 2004. Geologia e petro-metalogênese da mineralização de ouro da mina São Bento, Quadrilátero Ferrífero - MG. MSc Dissertation, Instituto de Geociências, Universidade de São Paulo, São Paulo, 55 p. http://dx.doi.org/10.11606/D.44.2004.tde-17092013-132357

Verma S.K., Oliveira E.P., Silva P.M., Moreno J.A., Amaral W.S. 2017. Geochemistry of komatiites and basalts from the Rio das Velhas and Pitangui greenstone belts, São Francisco Craton, Brazil: Implications for the origin, evolution, and tectonic setting. Lithos, 284-285, 560 577. https://doi.org/10.1016/j.lithos.2017.04.024

Vial D.S. 1980. Geologia da Mina de Ouro de Raposos. In: Congresso Brasileiro de Geologia, 31, 1851-1866.

Vial D.S., Abreu G.C., Schubert G., Ribeiro-Rodrigues L.C. 2007. Smaller gold deposits in the Archean Rio das Velhas greenstone belt, Quadrilátero Ferrífero, Brazil. Ore Geology Reviews, 32(3-4), 651673. https://doi.org/10.1016/j.oregeorev.2005.01.004

Vial D.S., Ferreira Jr. M.G., Ferrari P.G. 1987. A lapa seca na Mina de Morro Velho: Metavulcanitos alterados hidrotermalmente. In: Simpósio de Geologia de Minas Gerais, 4, 369-390.

Vieira F.W.R. 1991. Textures and processes of hydrothermal alteration and mineralization in the Nova Lima Group, Minas Gerais, Brazil. In: Ladeira E.A. (ed.). Brazil Gold '91: The economics, geology, geochemistry and genesis of gold deposits. Balkema, Rotterdam, p. 319-325.

Zucchetti M. 1998. Geoquímica dos metabasaltos do Grupo Nova Lima, Supergrupo Rio das Velhas, Quadrilátero Ferrífero, Minas Gerais. MSc Dissertation, Instituto de Geociências, Universidade Federal de Minas Gerais, Belo Horizonte, 124 p. Available on line at: http://rigeo.cprm. gov.br/jspui/handle/doc/14680 (accessed on 16 September 2020)

Zucchetti M., Baltazar O.F. 2000. Projeto Rio das Velhas: Texto explicativo do mapa geológico integrado. Escala 1:100.000. 2nd reprint. Belo Horizonte, DNPM, CPRM. $116 \mathrm{p}$.

Zucchetti M., Baltazar O.F., Raposo F.O. 2000c. Estratigrafia. In: Zucchetti M., Baltazar O.F. (ed.). Projeto Rio das Velhas: Texto explicativo do mapa geológico integrado. Escala 1:100.000. 2nd reprint. Belo Horizonte, DNPM, CPRM. 13-41.

Zucchetti M., Lobato L.M., Baars F.J. 2000a. Genetically diverse basalt geochemical signatures developed in the Rio das Velhas Greenstone Belt, Quadrilátero Ferrífero, Minas Gerais, Brazil. Revista Brasileira de Geociências, 30(3), 397-402. http://dx.doi.org/10.25249/03757536.2000303397402

Zucchetti M., Lobato L.M., Baltazar O.F. 2000b. Volcanic and volcaniclastic features in Archean rocks and their tectonic environment, Rio das Velhas Greenstone Belt, Quadrilátero Ferrífero, MG - Brazil. Revista Brasileira de Geociências, 30(3), 388-392. http://dx.doi. org/10.25249/0375-7536.2000303388392 